\title{
Bioreactor Landfill Research and Demonstration Project Northern Oaks Landfill, Harrison, MI \\ FINAL REPORT
}

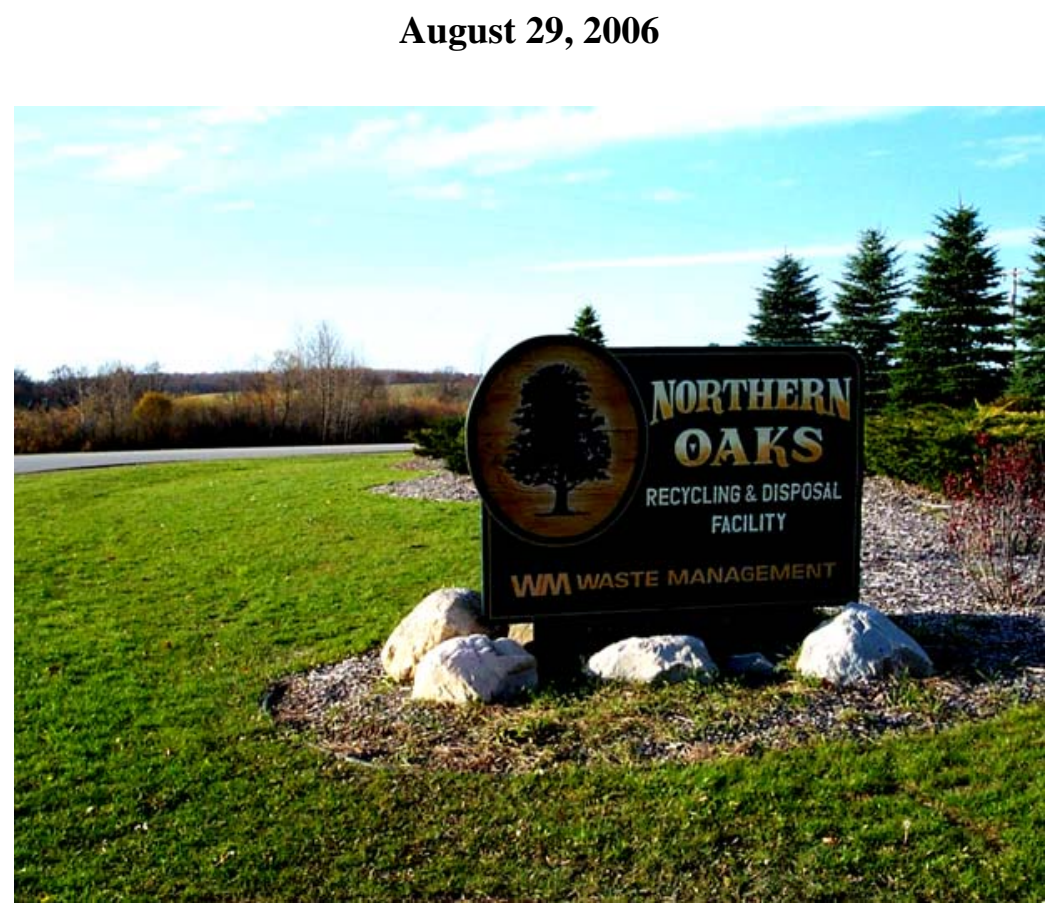

Submitted to:

Environmental Research and Education Foundation

Submitted by:

Xianda Zhao

Research Assistant Professor

Thomas Voice

Professor

Syed A. Hashsham

Associate Professor

Department of Civil and Environmental Engineering 


\section{EXCECTIVE SUMMARY}

A bioreactor landfill cell with 1.2-acre footprint was constructed, filled, operated, and monitored at Northern Oaks Recycling and Disposal Facility (NORDF) at Harrison, MI. With a filled volume of 74,239 cubic yards, the cell contained approximately 35,317 tons of municipal solid waste (MSW) and 20,777 tons of cover soil. It was laid on the slope of an existing cell but separated by a geosynthetic membrane liner. After the cell reached a design height of 60 feet, it was covered with a geosynthetic membrane cap. A three-dimensional monitoring system to collect data at 48 different locations was designed and installed during the construction phase of the bioreactor cell. Each location had a cluster of monitoring devices consisting of a probe to monitor moisture and temperature, a leachate collection basin, and a gas sampling port.

An increase in moisture content of the MSW in the bioreactor cell was achieved by pumping leachate collected on-site from various other cells, as well as recirculation of leachate from the bioreactor landfill cell itself. Three types of leachate injection systems were evaluated in this bioreactor cell for their efficacy to distribute pumped leachate uniformly: a leachate injection pipe buried in a 6-ft wide horizontal stone mound, a 15-ft wide geocomposite drainage layer, and a 60-ft wide geocomposite drainage layer. All leachate injection systems were installed on top of the compacted waste surface. The distribution of water and resulting MSW moisture content throughout the bioreactor cell was found to be similar for the three designs. Water coming into and leaving the cell (leachate pumped in, precipitation, snow, evaporation, and collected leachate) was monitored in order to carry out a water balance. Using a leachate injection rate of $26-30$ gal/yard ${ }^{3}$, the average moisture content increased from 25\% to 35\% (wet based) over the period of this study.

One of the key aspects of this bioreactor landfill study was to evaluate bioreactor start up and performance in locations with colder climate. For lifts filled during the summer months, methane generation started within three months after completion of the lift. For lifts filled in winter months, very

little methane production occurred even eight months after filling. The temperature data indicated that subzero or slightly above zero $\left({ }^{\circ} \mathrm{C}\right)$ temperatures persisted for unusually long periods (more than six months) in the lifts filled during winter months. This was likely due to the high thermal insulation capability of the MSW and the low level of biological activity during start up. This observation indicates that bioreactor landfills located in cold climate and filled during winter months may require mechanisms to increase temperature and initiate biodegradation. Thus, besides moisture, temperature may be the next important factor controlling the biological decomposition in anaerobic bioreactor landfills. 
Spatial and temporal characterization of leachate samples indicated the presence of low levels of commonly used volatile organic compounds (including acetone, methyl ethyl ketone, methyl isobutyl ketone, and toluene) and metals (including arsenic, chromium, and zinc). Changes and leachate and gaseous sample characteristics correlated with enhanced biological activity and increase in temperature. Continued monitoring of this bioreactor landfill cell is expected to yield critical data needed for start up, design, and operation of this emerging process. 


\section{TABLE OF CONTENTS}

EXCECTIVE SUMMARY ii

TABLE OF CONTENTS iv

1. INTRODUCTION 1

2. SPECIFIC AIMS 3

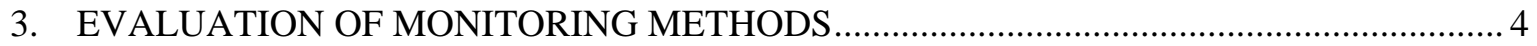

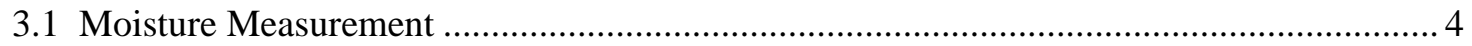

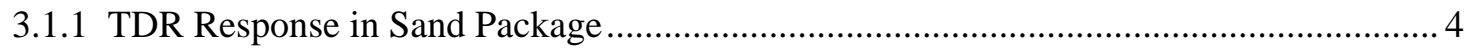

3.1.2 TDR Response to Total Dissolved Solid (TDS) Concentration....................................... 6

3.1.3 Reproducibility of the TDR Response in Compacted Municipal Solid Waste .................. 7

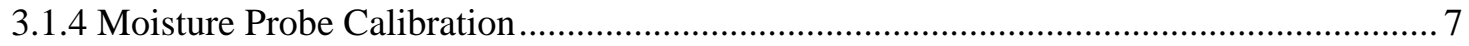

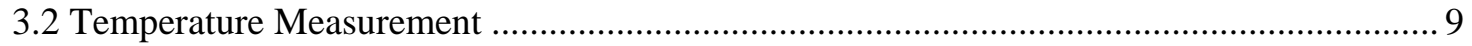

3.3 Chemical Constituents in Leachate and Gas ................................................................... 9

4. CONSTRUCTION OF THE BIOREACTOR LANDFILL CELL …....................................... 12

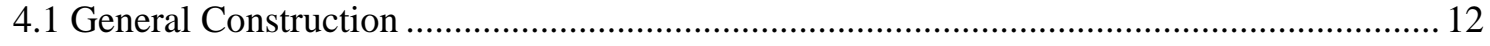

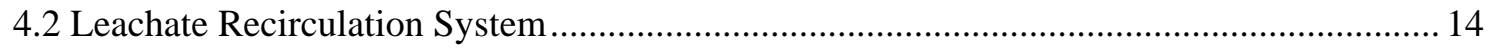

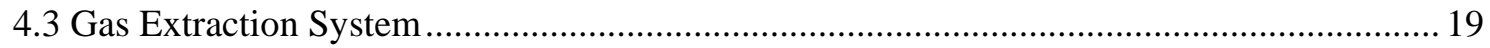

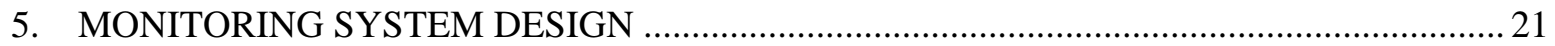

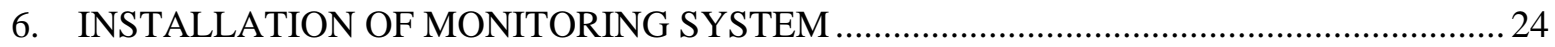

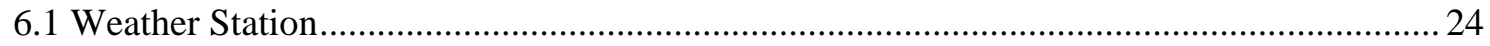

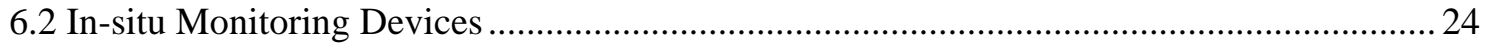

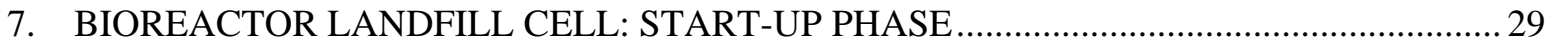

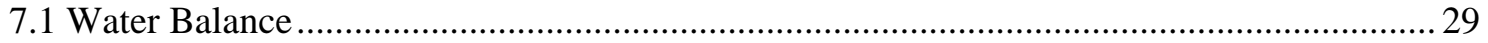

7.2 Moisture Distribution in the Bioreactor Landfill ................................................................... 31 
7.3 Leachate Sample Collected from In-situ Leachate Basins................................................ 39

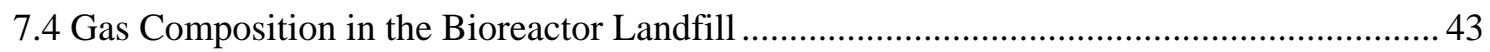

7.5 Leachate Characteristics in Sump Bioreactor Landfill .................................................... 46

7.6 Differential Settlements in the Bioreactor Landfill........................................................... 51

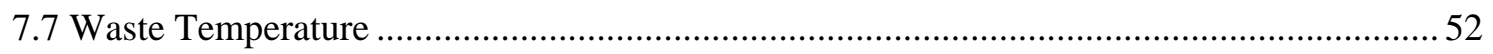

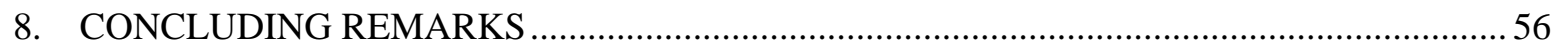

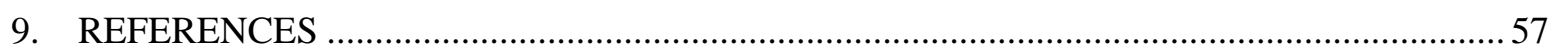




\section{CHAPTER 1: INTRODUCTION}

U. S. residents and businesses generated 236 million tons of municipal solid waste (MSW) in 2003 (www.epa.gov/epaoswer/non-hw/muncpl/facts.htm). Approximately 131 million tons of this MSW was buried in 1,767 landfills. The balance was combusted or recycled. To minimize the adverse effect of MSW landfill on groundwater, U.S. regulations require landfills to be designed with impermeable liners and leachate collection systems. Regulations also require a low permeability cap to prevent liquid intrusion after closure and landfill gas extraction system to prevent air emissions. The goal is to minimize the amount of water entering the landfill. As a result, the deposited MSW is encapsulated under low moisture conditions often referred to as the “dry tomb” approach of managing landfills. However, biological degradation does occur, albeit at a slow rate, as a result of water originally present in the MSW as well as some that entered prior to installation of the final cap. The result is that while degradation may be moisture-limited, landfills are biologically active for decades. Thus air and water emissions from landfills must be monitored, controlled, and treated for a long time (Barlaz et al., 1990; McCreanor and Reinhart, 1999; Mehta et al., 2002; Pacey et al., 1999; Pohland, 1980; Reinhart et al., 2002; Townsend et al., 1996; Yuen et al., 2001).

Bioreactor landfills, on the other hand, actively inject leachate or other liquids to address moisture limitations, thereby significantly enhancing the rate and extent of biodegradation (Maier et al., 1995; Pacey et al., 1999; Pohland, 1980). Injecting leachate and air enhances aerobic biodegradation and results in considerable production of heat (Figure 1-1, upper limb). Injection of leachate alone enhances anaerobic degradation ultimately leading to the production of methane (Figure 1-1, lower limb). Because methane can be recovered and used to produce energy, it is more economical to use anaerobic process. Other potential benefits of bioreactor landfills include increased landfill capacity, reduced cost of postclosure care, reduced post-closure settlement, and reduced impact on the environment. Bioreactor landfills have the potential to provide a more sustainable approach (compared to traditional landfills) to manage MSW because they actively manage the biodegradable portion of MSW (Augenstein et al., 1997).

At present, more than 20 full-scale demonstration projects are in progress in North America (SWANA, 2002). Some of these projects involve the addition of leachate, recirculation, and gas collection system in previously closed landfill cells (e.g., New River Regional Landfill in Union County, FL, Outer Loop Landfill "Facultative Bioreactor” in Louisville, KY, and Williamson County Landfill in Williamson County, TN). Others are designed and built as bioreactor landfill cells (e.g., Bluestem Landfill in Marion, IA, Buncombe County Landfill in NC, Maplewood and King George County Landfills in VA, Outer Loop Landfill "Hybrid Bioreactor" in Louisville, KY, Sainte Sophie Landfill in Quebec, Canada, and Yolo County Landfill in CA). A variety of design and operational questions were studied in the above projects (Augenstein et al., 1997; Barry and Demme, 1997; Dahl, 1998; Maier et al., 1995; Moore et al., 1997; Pagano et al., 1998; Townsend et al., 1994; Warzinski et al., 2000; Wilson et al., 2000). Nonetheless, some critical information is still lacking regarding the amount of leachate required to increase the moisture content, the resulting rate and extent of biodegradation, the 
impact of leachate addition on liners, the environmental impacts of an increased rate of gas emissions, and the net impact on carbon sequestration (NETL 2005). Projects undertaken by the EPA's Project XL Bioreactor Landfill Program are designed to study many of these issues (http://www.epa.gov/garbage/landfill/bioreactors.htm\#5).

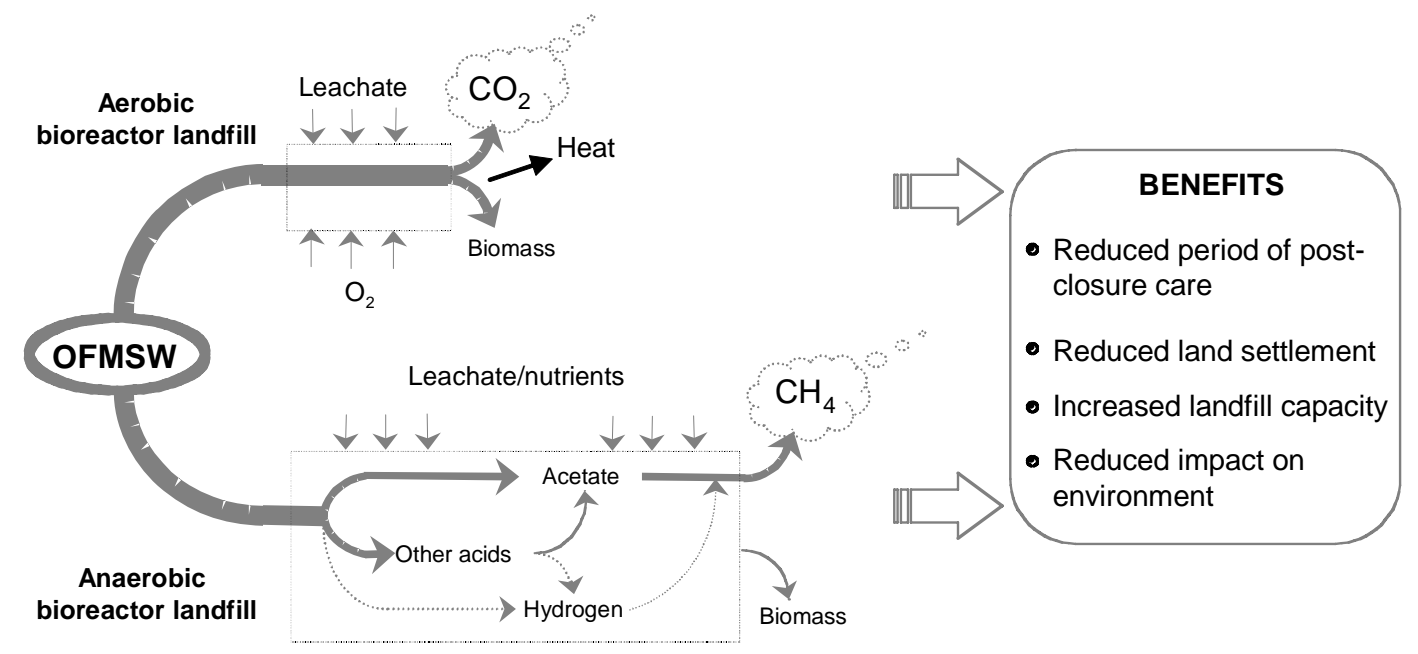

Figure 1-1: Major biological activity in aerobic and anaerobic bioreactor landfills and their potential benefits (OFMSW = organic fraction of municipal solid waste).

The present report summarizes the findings during the start-up phase of a bioreactor landfill cell located at the Northern Oaks Recycling and Disposal Facility (NORDF), Harrison, MI. This study was funded by the Environmental Research and Education Foundation with funds from the Department of Energy and a gift from the Daimler Chrysler Corporation. It was conducted in collaboration with Waste Management, Inc. This bioreactor cell, although small by most standards (1.2-acre), represents one of the most heavily instrumented cells containing a three-dimensional grid of temperature and moisture probes, leachate collection basins, and air sampling ports (48 locations). The construction and filling of the landfill was completed in the spring of 2003. The system has been monitored continuously since then. This document is the final report related to the construction phase of this bioreactor landfill. Studies related to its continued performance will be reported in peer-review journals. 


\section{CHAPTER 2: SPECIFIC AIMS}

The bioreactor landfill cell at Northern Oaks Recycling and Disposal Facility (NORDF) was designed to monitor multiple parameters in a three-dimensional grid of 48 locations. At each location, a system of probes and sampling ports was installed to study the heterogeneity in moisture content, waste temperature, leachate characteristics, and gas composition. The study was specifically designed to understand the effect of cold weather conditions on the operation of the bioreactor landfill. The data collected was used to develop a better understanding of the start-up phase of a bioreactor landfill located in colder climate. This bioreactor landfill cell is one of very few bioreactor landfills located in the northern part of the United States and first in the state of Michigan. The following specific aims were set for this project.

1. Evaluate the impact of colder climate (zero to sub-zero conditions) on the start-up phase of bioreactor landfill cells,

2. Evaluate the spatial heterogeneity in water content, temperature, leachate characteristics, and gas characteristics,

3. Evaluate the efficacy of various leachate injection systems,

4. Provide an educational resource for site operators, regulators, and graduate students, and

5. Establish an anaerobic bioreactor landfill cell with probes and sampling ports for long-term studies. 


\section{CHAPTER 3: EVALUATION OF MONITORING METHODS}

\subsection{Moisture Measurement}

Moisture content is known to affect the decomposition rate of MSW significantly. However, due to the paucity of suitable methods and heterogeneity of waste, monitoring this in situ is a challenge. An accurate measure of moisture content can be produced by the gravimetric method, where waste samples are collected using a drill auger, samples are homogenized, and subsamples are analyzed by drying and weighing. However, this process is cumbersome, costly, and gives only a "snapshot" of the moisture content at the sampling location. It does not give the real time moisture content of the MSW. To continuously monitor moisture content in MSW, as may be required to study the performance of a leachate distribution system, nondestructive and reliable methods are needed. Time Domain Reflectometry (TDR) holds promise, if proper calibration and durability of probe in the harsh landfill matrix can be accomplished. TDR technology has been used to manage the moisture content of agricultural soil and golf courses for many years. It is based on the measurement of the dielectric constant of the area surrounding the probe. Because of the large difference between the dielectric constant of water (80) compared to other materials (dielectric constant of air is 1 and that of soil varies between 3 to 5 ), the water content can be calculated from the overall dielectric constant measured by TDR (Li and Zeiss, 2001).

Many different TDR probes are available commercially. After reviewing the literature and discussing with several TDR probe manufactures, the following criteria for selection of a suitable probe was developed:

(i) The probe should perform in high salt concentrations expected to be present in leachate,

(ii) Performance should be reproducible,

(iii) The probe should be economical for installation at numerous locations for replicate measurements, and

(iv) A long cable length (longer than $200 \mathrm{ft}$ ) must be possible.

After checking with several TDR probe manufacturers, a probe manufactured by Automata, Inc. was selected for this evaluation (Figure 3-1). This probe is protected with epoxy and the electronic module is attached to one end of the probe body. The epoxy body was expected to improve the resistance to the corrosive condition of the landfill. The electronic module eliminated the maximum cable length requirements (normally $150 \mathrm{ft}$ ) for some probes.

\subsubsection{TDR Response in Sand Package}

To evaluate the linearity of the TDR response, silica sand was mixed with deionized (DI) water (specific electrical conductivity, EC $=13.9 \mathrm{uS}$ ) or sodium chloride solutions $(\mathrm{EC}=48.9 \mathrm{mS}$ ) to produce

different moisture content. The moist sand was then packed around the probe and response of the probe was recorded. The relationship was linear for the sodium chloride solutions (Figure 3-2). 


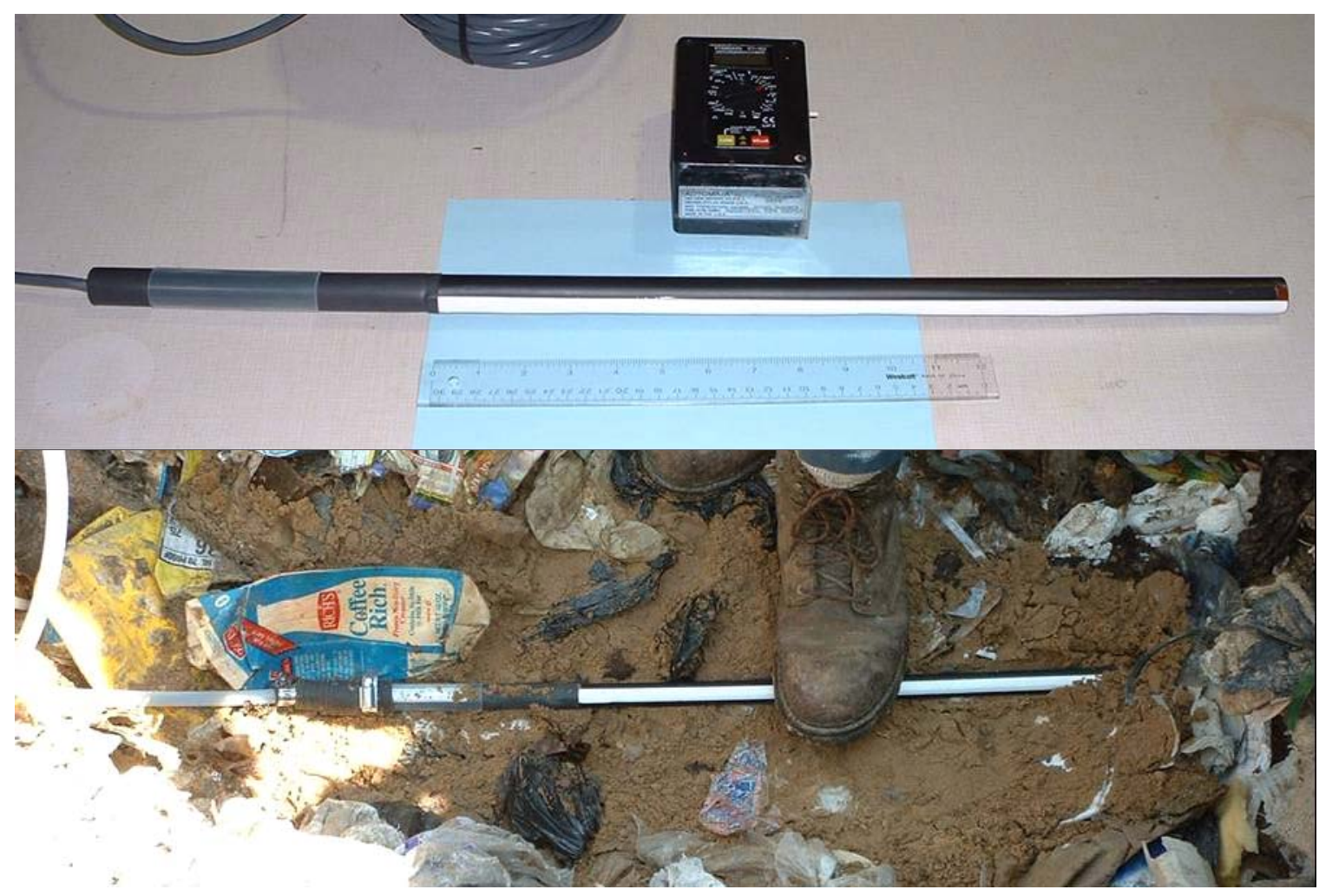

Figure 3-1: Automata ${ }^{\circledR}$ TDR probe placement

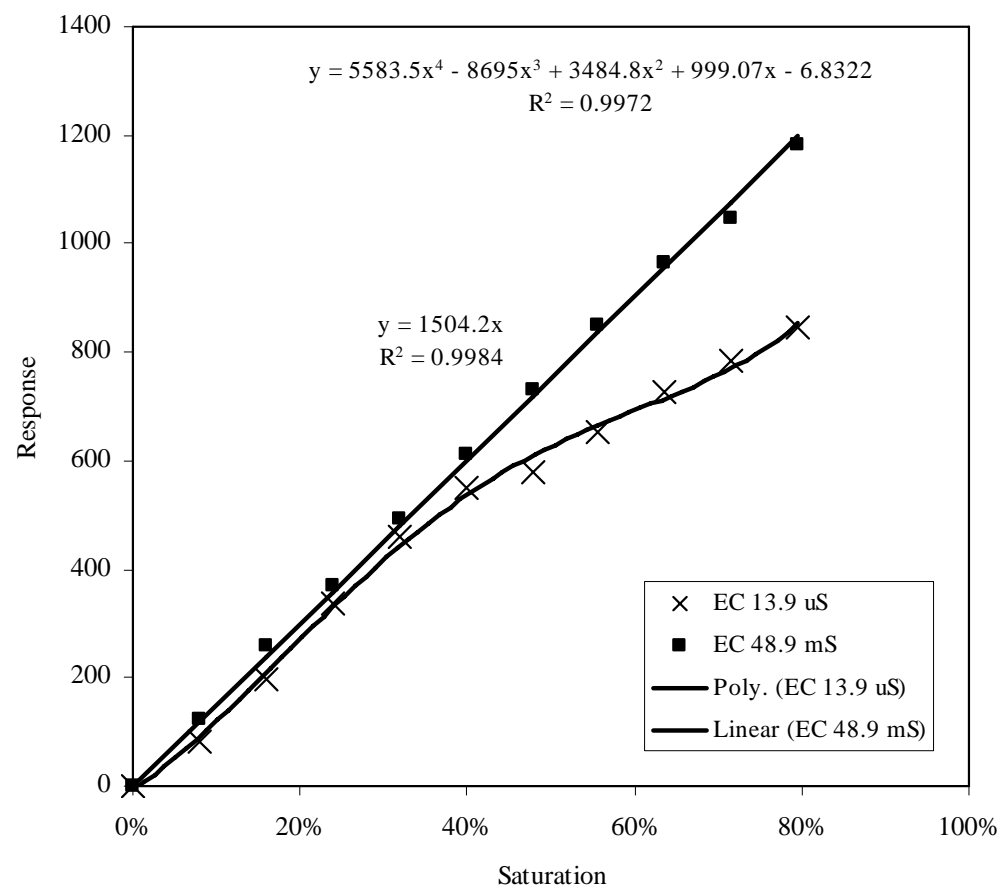

Figure 3-2: TDR responses at different saturation and solution electrical conductivity in sand 


\subsubsection{TDR Response to Total Dissolved Solid (TDS) Concentration}

We assumed that the TDR response would vary with the TDS concentration of the liquid and designed a test to quantify this. A leachate sample was collected from Northern Oaks RDF landfill and found to have specific electrical conductivity (EC) of $13.6 \mathrm{mS}$. After submerging the TDR probe fully into the solution (100\% coverage), the TDR response was recorded. The solution was then diluted with DI water and the EC and TDR response were again recorded. This process was repeated for several dilutions. To verify the cause of the interference, $\mathrm{NaCl}$ solution was prepared at same EC values. The TDR response was recorded in this solution. The TDR reading increased with the EC values (Figure 3-3). There was no significant difference in TDR probe response between the two solutions, especially at low EC levels (below $6 \mathrm{mS}$; Figure 3-3). The response of TDR was slightly lower in the leachate compared to $\mathrm{NaCl}$ solution at high EC values. These results indicated that $\mathrm{NaCl}$ solution can be effectively used to evaluate the TDR probe performance before installation.

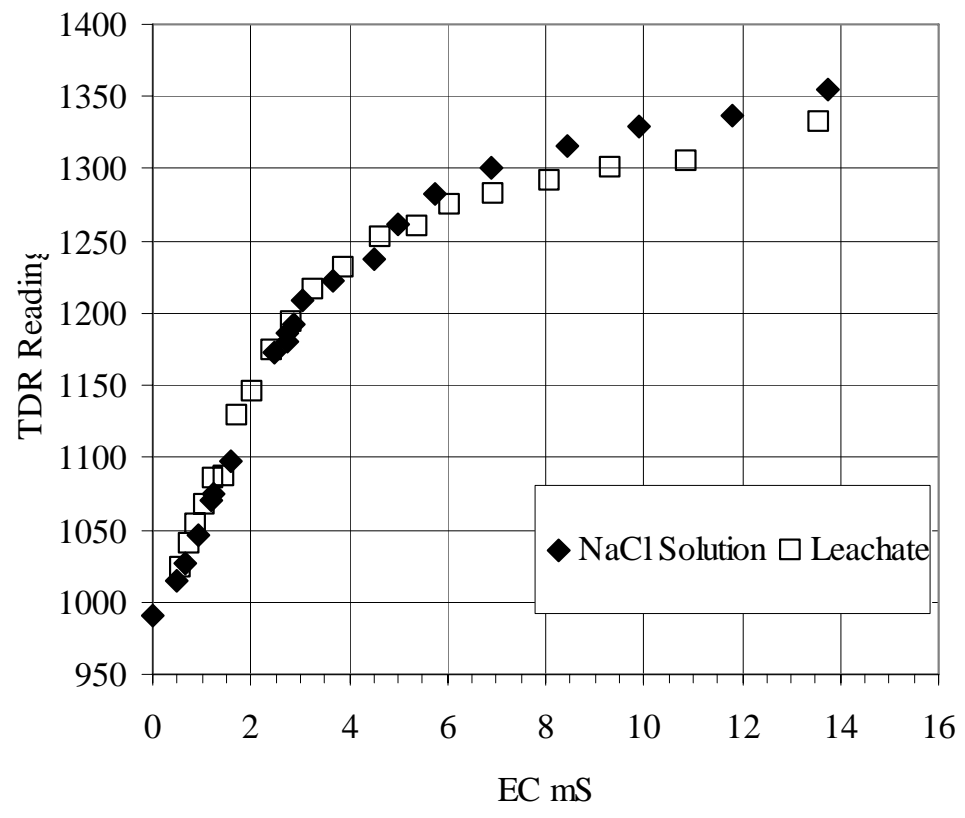

Figure 3-3: TDR response at various EC solutions

To compare the effect of EC on the TDR response to that expected from changes in saturation, three $\mathrm{NaCl}$ solutions were prepared: $5.3 \mathrm{mS}, 11.5 \mathrm{mS}$ and $21.5 \mathrm{mS}$. A fixed length of the active length of the probe (25\%, 50\% and 100\%) was submerged into the solution, and the TDR response was recorded. The percentage submerged can be used to represent the different water content in the waste. This probe was designed to yield an output signal between 0 and 1 milliamp proportional to the water coverage along the length of the probe. Using pure water, one milliamp output corresponds to $100 \%$ coverage. As the salt concentration increased, the output from the TDR also increased. The TDR response was linear with respect to the percent submerged and the EC level in the solution had minimal impact on this response (Figure 3-4). This result indicated that the probe response did not need to be adjusted with the salt (EC) values in the leachate. 


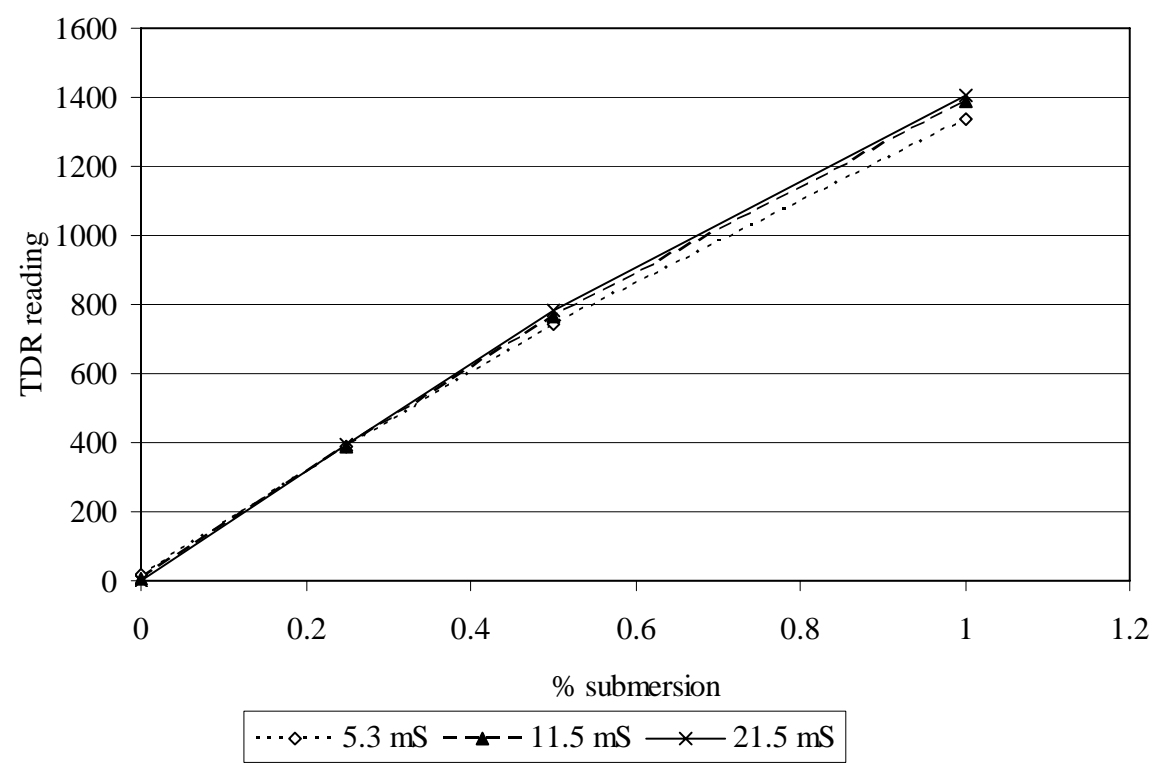

Figure 3-4: TDR response to percent submersion in solution

\subsubsection{Reproducibility of the TDR Response in Compacted Municipal Solid Waste}

To conclude the preliminary evaluation, the reproducibility of the probe was evaluated with the MSW obtained from the Northern Oaks landfill site. The TDR probe was buried in the MSW by removing the daily soil cover on the working face and its response was recorded before and after manual compaction. The results are shown in Table 3-1 (four independent readings). The TDR reading increased as a result of compaction most likely due to the enhanced contact between the probe and the MSW. The results were reproducible and the reproducibility increased with compaction. Based on these results, it can be concluded that the selected TDR probe should perform reasonably well in the environment found in landfills.

\subsubsection{Moisture Probe Calibration}

The TDR moisture probes used were designed for soil applications - i.e., under relatively homogenous and stable conditions. Because the probes were buried in MSW, they had to be calibrated to obtain the absolute moisture content. The calibration employed a synthetic waste mixture representative of the MSW used to bury the probes. The synthetic MSW consisted of paper, plastic, textile, and soil in mass fractions $62 \%, 14 \%, 12 \%$, and $12 \%$, respectively. These percentages were selected based on information provided in "Characterization of Municipal Solid Waste in the United States; U.S. EPA, 1992"-normalized to $100 \%$. Textile and soil were assumed to be present in equal fractions. Yard trimmings, metals, glass, food, and certain miscellaneous fractions were not included in the synthetic waste mixture because they did not comprise a significant fraction of the waste used to bury the TDR moisture probes in the field. These fractions were also avoided during burial of the probe. 
Table 3-1: Response of TDR Probe in compacted MSW

\begin{tabular}{|c|c|c|c|c|c|c|}
\hline & Test 1 & Test 2 & Test 3 & Test 4 & Average & $1 \mathrm{std}$ dev \\
\hline $\begin{array}{l}\text { Before } \\
\text { Compaction }\end{array}$ & $26 \%$ & - & $19 \%$ & $29 \%$ & - & - \\
\hline $\begin{array}{l}\text { After } \\
\text { Compaction }\end{array}$ & $34 \%$ & $35 \%$ & $32 \%$ & $36 \%$ & $34.2 \%$ & $1.7 \%$ \\
\hline
\end{tabular}

A rectangular box was constructed for the TDR calibration. The box had a volume of 10 liters and was closed with top cover. Compaction could be increased by placing additional plates placed under the cover. Six sets of clamps were used to provide the compaction pressure (Figure 3-5). The waste was wetted using tap water containing $\mathrm{NaCl}(\mathrm{EC}=20.30 \mathrm{mS})$. Water was added in increments and compaction was also changed after each incremental water addition to produce different volumetric moisture content (VMC). The VMC was calculated by dividing the total volume of water added by the volume of the test chamber. The dry density of the packed MSW was in the range of 0.11 to 0.22 ton/yard ${ }^{3}$ and the wet density was in the range of 0.21 to 0.56 ton/yard ${ }^{3}$. A linear relationship given by the following equation was found between the measured moisture content $\left(\mathrm{M}_{\mathrm{m}}\right)$ and calibrated or "true" moisture content $\left(\mathrm{M}_{\mathrm{c}}\right)$ (Figure 3-6):

$$
\mathrm{M}_{\mathrm{c}}=0.62 \mathrm{M}_{\mathrm{m}}+0.028
$$

The volumetric moisture content reported in the Results section was corrected using this calibration curve.

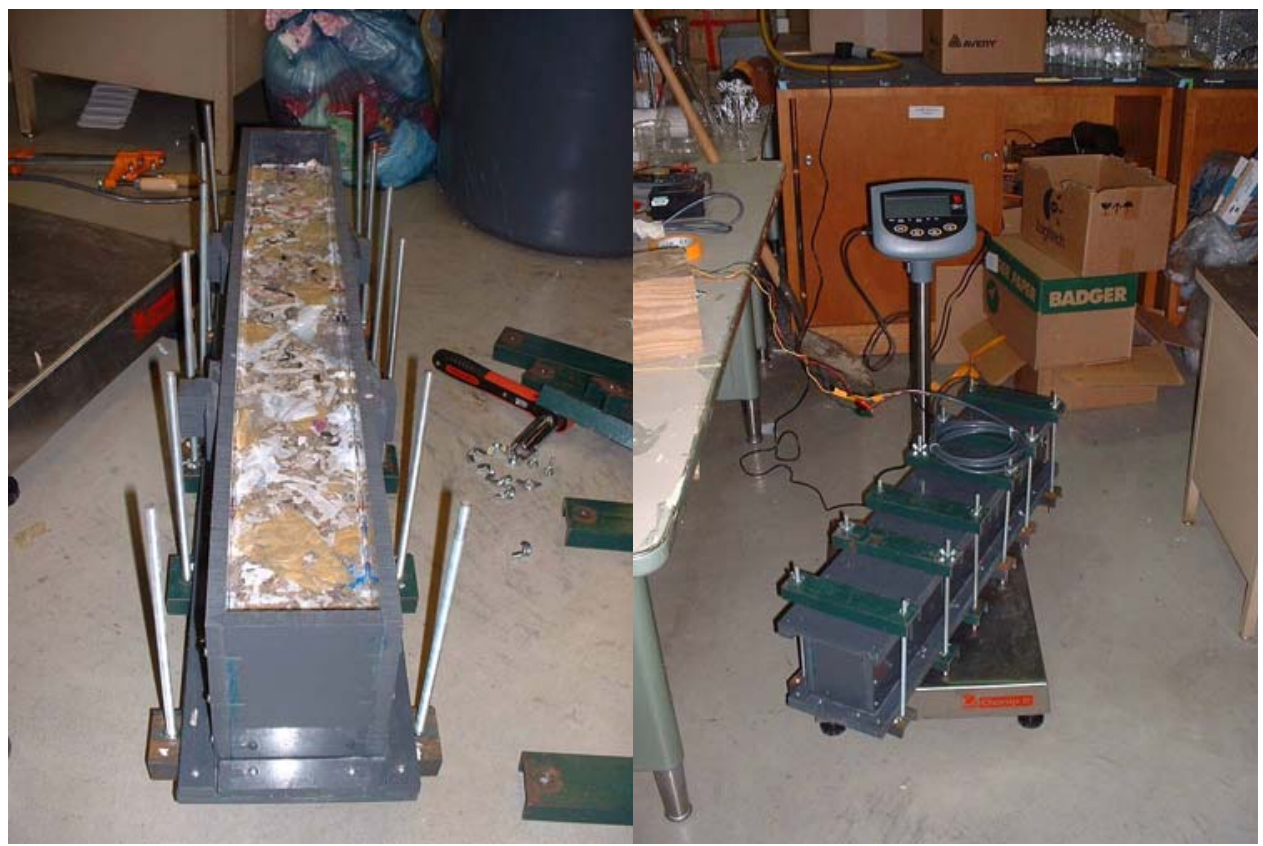

Figure 3-5. The TDR calibration setup 


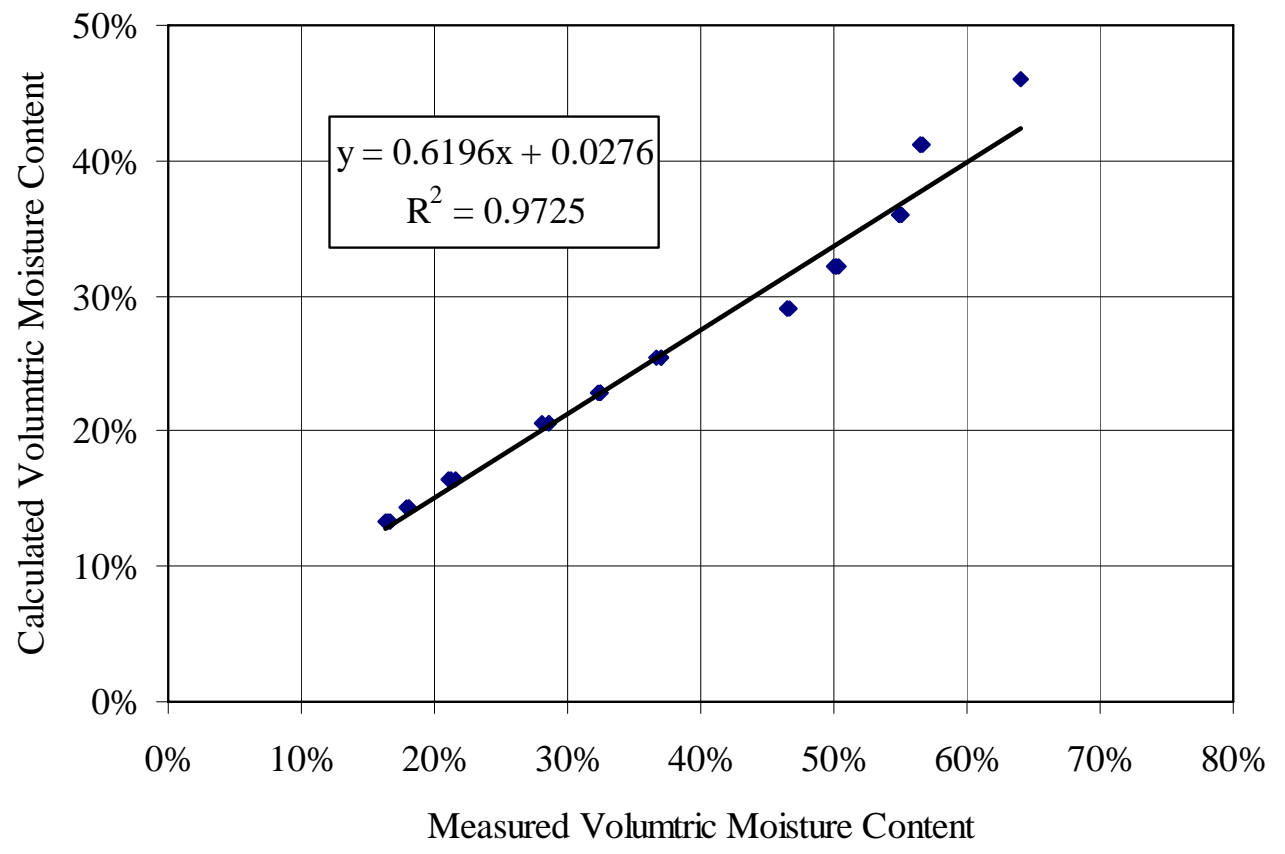

Figure 3-6: The TDR calibration

\subsection{Temperature Measurement}

The waste temperature was monitored with the temperature sensor available as part of the TDR probe. The temperature reading from each probe was verified by comparison to a mercury thermometer at three different temperatures before installation (data not shown).

\subsection{Chemical Constituents in Leachate and Gas}

Chemical characteristics of the leachate and composition of the landfill gas are important parameters for monitoring the system performance and for evaluating various processes occurring in a bioreactor landfill. Leachate samples are commonly collected from the leachate collection sump for chemical analysis. Landfill gas can be collected from the gas extraction well or pipes. However, because these represent composite samples, they do not provide information about performance variations within the cell. Optimizing performance will likely require an understanding of process variations within the cell and the development of strategies to eliminate those zones that face limitations. We therefore developed an approach for obtaining spatial samples for leachate and gas in addition to temperature and moisture.

The leachate sample collection system consisted of a basin, a tube insert, a cover, and a sampling tube extending horizontally to the surface of the cell (Figure 3-7). A polyethylene molded rectangular plastic bucket (8.85” wide x 11” high; ACO Polymer Product, Inc. OH) with a total volume of 14 liters served as the leachate collection basin. The tube insert was designed to hold the sampling tube in the center of the basin and to minimize solids entering into the opening of the sampling tube. A perforated cover was used 
to prevent pieces of waste from entering the basin while allowing leachate flow. The sampling tube (3/8” OD, 1/4" ID polyethylene) provided the access to the basin from outside the bioreactor cell using a peristaltic pump.

The leachate collection basin was tested for strength using a loading frame without side support (Figure 3-8). The basin was able to withstand approximately $1700 \mathrm{lbs}$, which is equivalent to a load resulted from $48 \mathrm{ft}$ of MSW (at a density of $65 \mathrm{lbs} / \mathrm{ft} 3$ ) without considering the arching load reduction. At failure, it deformed instead of cracking. Note that the basin was buried in the waste mass and packed with sand around the basin to provide the side support. Under this condition, the basin should be able to withstand even higher loading than the test value.

The gas sample collection system consisted of a 1/4" polyethylene tubing with a 1"x3" perforated pipe at the sampling end as shown in Figure 3-9. The polyethylene tubing provided access to the gas sampling port from outside of the landfill cell. As with the leachate collection basin, the gas sample was pumped out using a peristaltic pump, collected in a serum bottle, and analyzed in the laboratory using gas chromatography.

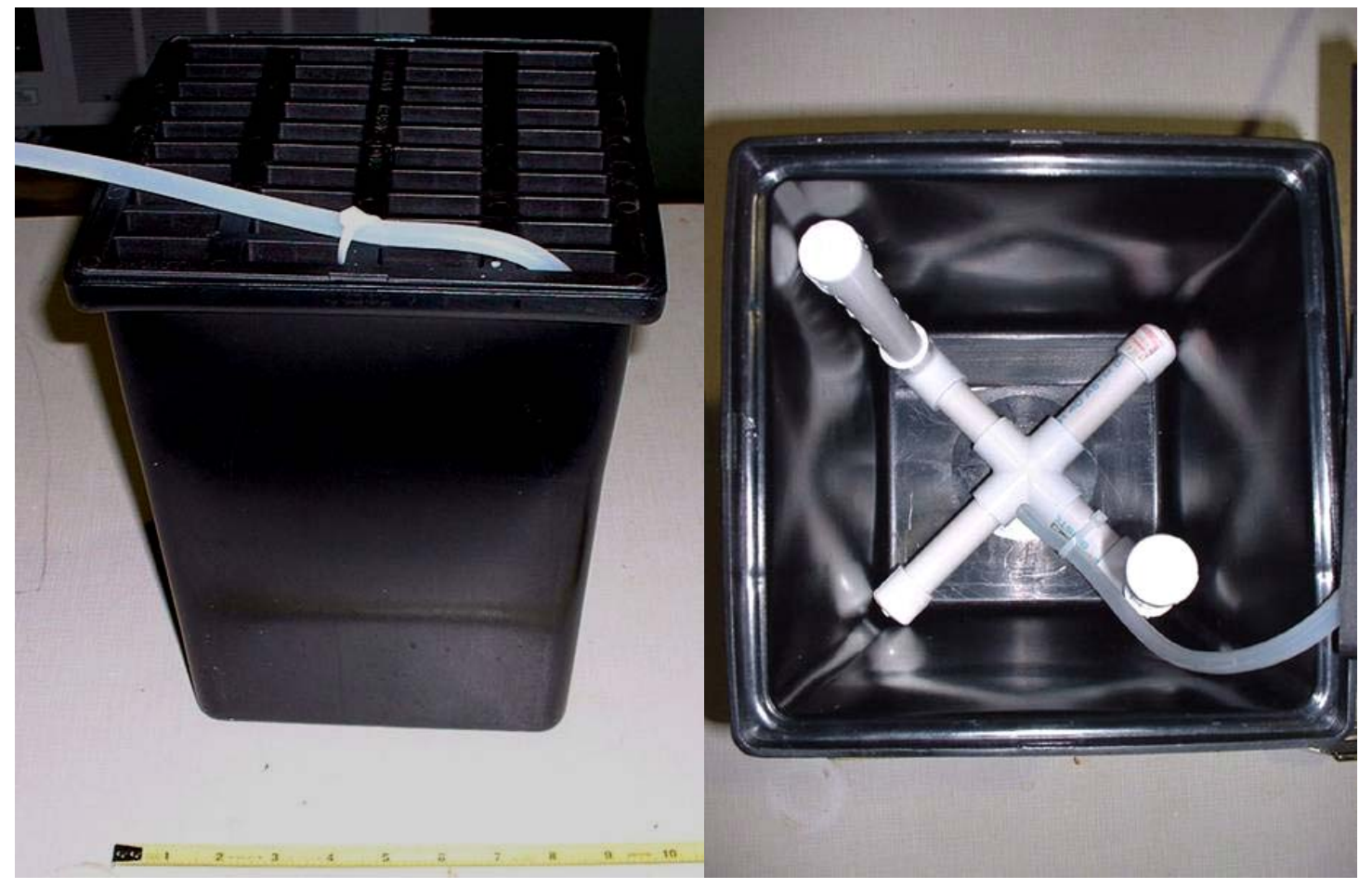

Figure 3-7: Leachate sampling basin 


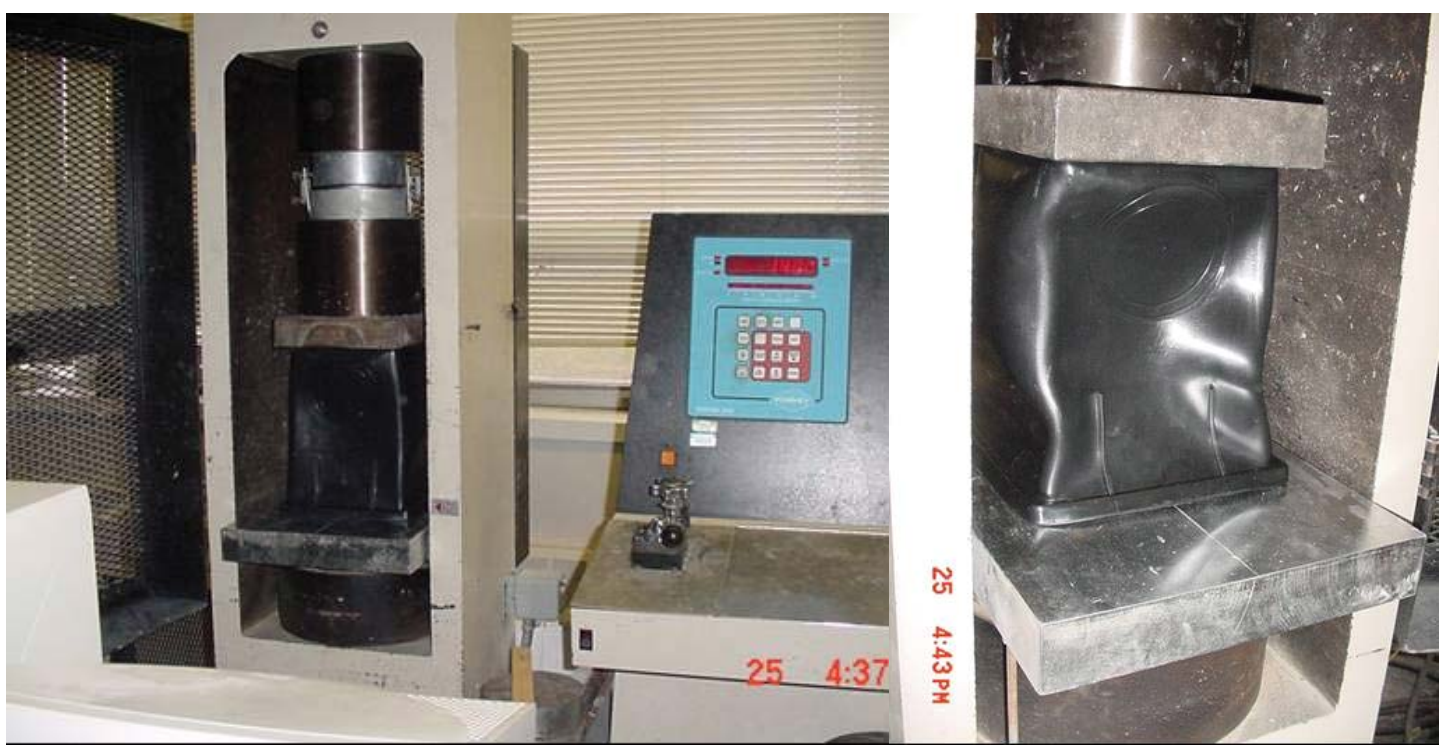

Figure 3-8: Stress test conducted on the leachate sampling basins

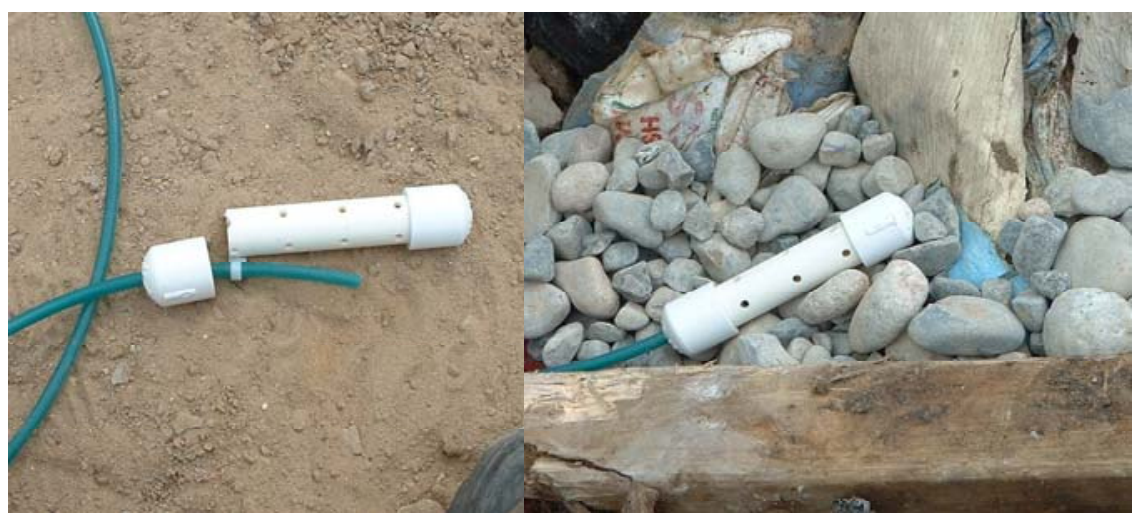

Figure 3-9: Gas sampling port 


\section{CHAPTER 4: CONSTRUCTION OF THE BIOREACTOR LANDFILL CELL}

\subsection{General Construction}

The Northern Oaks Recycling and Disposal Facility in Harrison, MI opened in December 1992. It occupies approximately 320 acres, of which 76 acres are designated for active use. The facility accepts approximately 500 tons of MSW per day for five days a week and has regulatory permission to recirculate leachate. At present, approximately $75 \%$ of leachate collected on site is recirculated either to the bioreactor landfill cell or to the working face of other cells (Zhao et al., 2004). The bioreactor cell was constructed on an undisturbed soil foundation, 10 feet below original grade, with a footprint of approximately 1.2 acres (Figure 4-1).

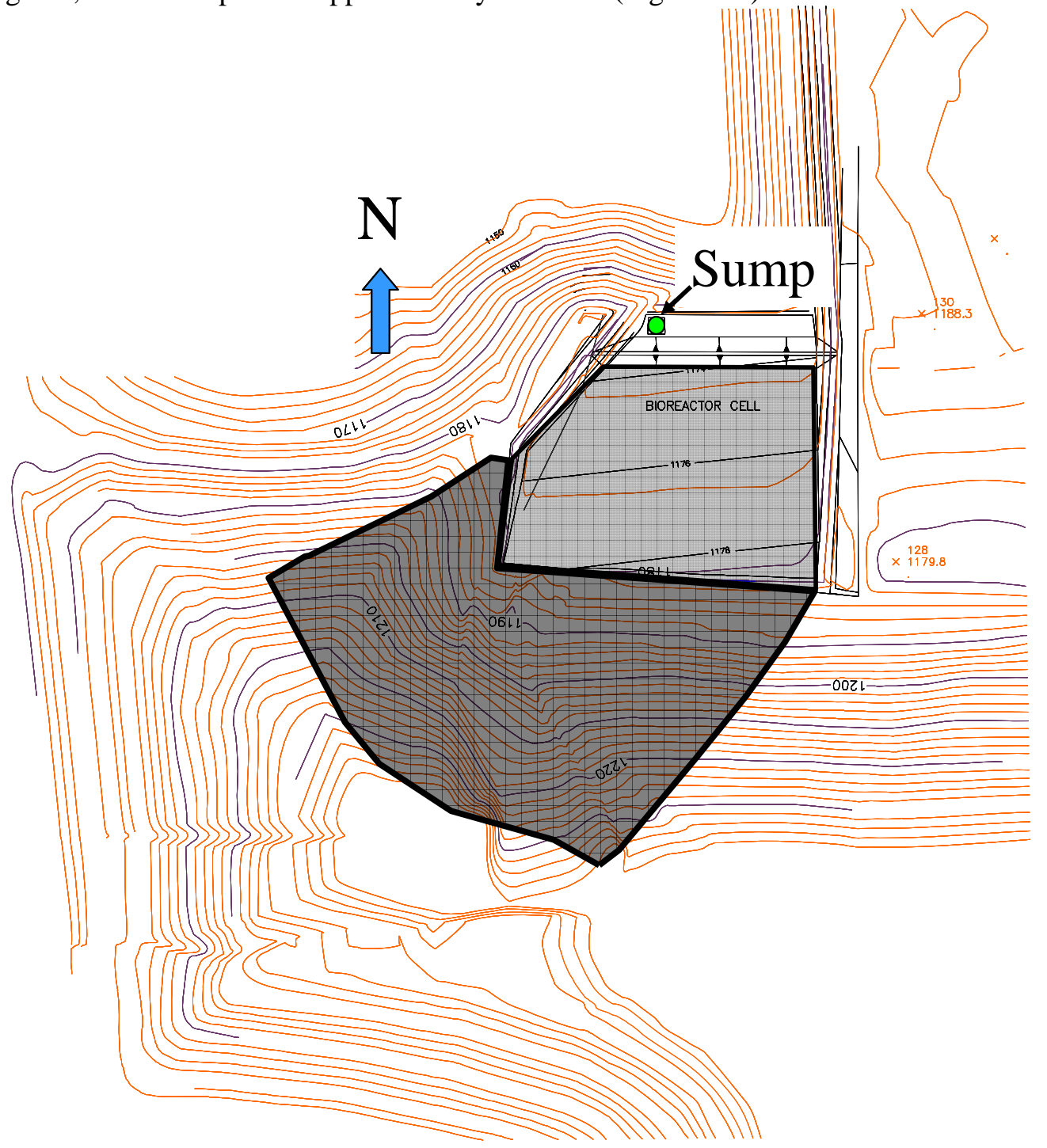

Source: Waste Management Inc.

Figure 4-1: The bioreactor landfill cell at NORDF 
The cell consisted of a double composite liner system under subtitle D and State of Michigan Part 115 regulations. The primary drainage layer consisted of a geocomposite layer protected with 12 inches drainage sand layer. Leachate collected with 6-inch diameter perforated HDPE pipes was transferred to a sump dedicated for the bioreactor cell. A 6-ft high temporary berm was installed on the north side to retain the leachate within the cell. The secondary drainage layer (geocomposite) was connected with a secondary drainage layer under a constructed cell. On the south side, the cell overlays an existing cellafter covering the existing cell with 12 inches of intermediate clay cover. To ensure isolation, a geomembrane (40 mil VFPE) layer was installed on the top of the intermediate cover between the two cells. A sand layer (12") was laid on top of the geomembrane to serve as a protective and drainage layer. The bioreactor cell was designed to be 60 feet in height with one $10-\mathrm{ft}$ lift at the bottom and ten $5 \mathrm{ft}$ subsequent lifts. After the final lift, the cell was closed with geomembrane cover in July 2003 (Zhao et al., 2003). A total of 35,317 tons MSW and 20,777 tons of cover soil was compacted in the cell. The airspace of the cell was 74,239 cubic yards. In addition, 6,642 tons of soil was placed above the geomembrane cap. The filling of the cell started on July 12, 2002 and the cell was closed with the cap on June 25, 2003 (Figure 4-2 and 4-3). The photos of the constructed cell are presented in Figure 4-4.

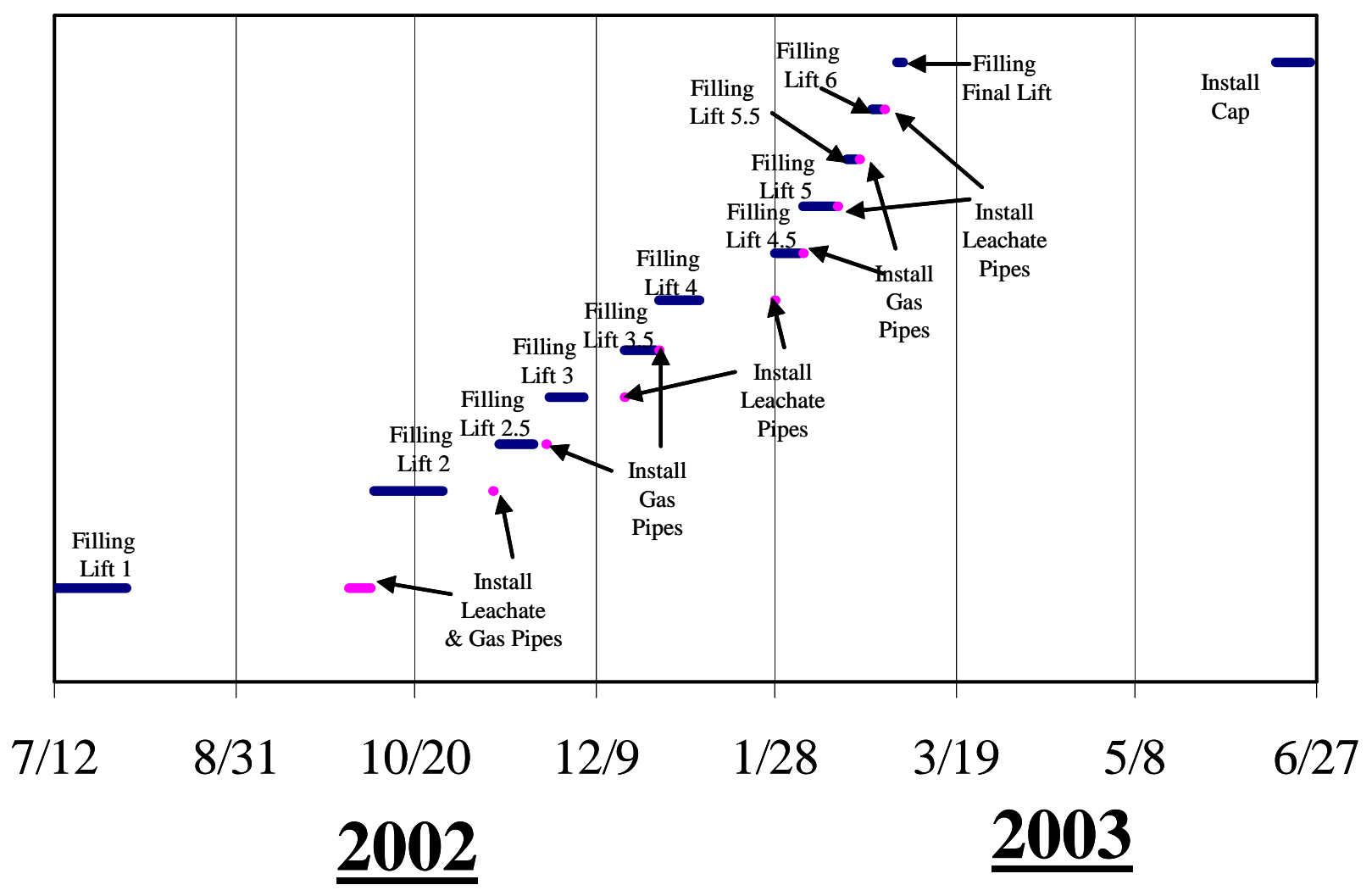

Figure 4-2: Construction timeline of the bioreactor landfill cell at NORDF 


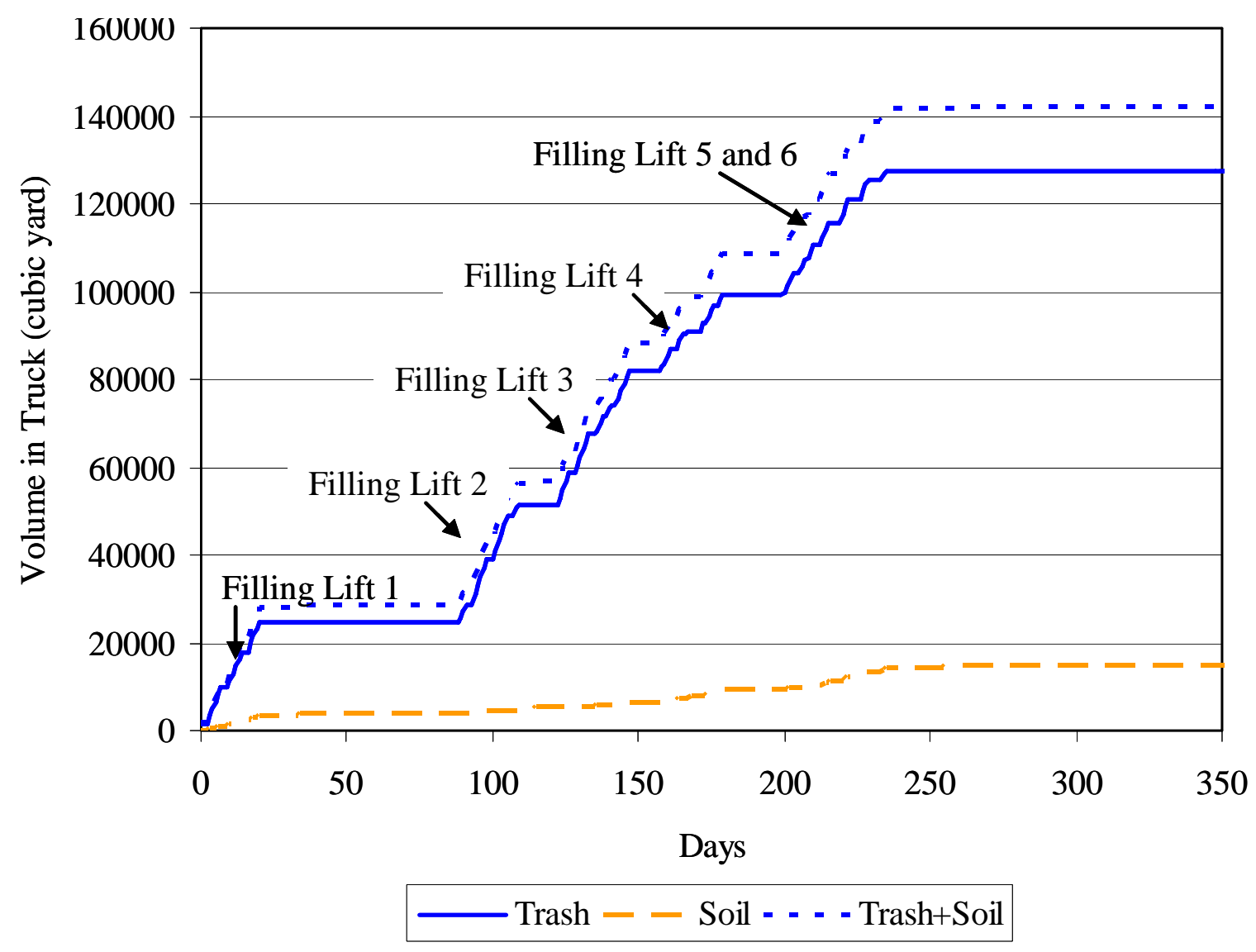

Figure 4-3: Filling of the landfill cell

\subsection{Leachate Recirculation System}

The design of the bioreactor cell required that approximately 48 probes and sampling ports be installed within the waste mass. Leachate recirculation lines (shown in magenta in Figure 4-5) and gas collection lines (shown in cyan in Figure 4-5) had to be installed for the cell to function as a bioreactor. The project employed three different leachate recirculation design configurations. The configurations were as follows:

- Horizontal leachate recirculation mound made of 4-inch diameter perforated HDPE pipes buried into a gravel layer (4 ft wide and $3 \mathrm{ft}$ high, Figure 4-6-A).

- $\quad$ 15-ft wide geocomposite drainage layer with one 4-inch perforated HDPE pipe in the center and a $2 \mathrm{ft}$ wide and $1 \mathrm{ft}$ high gravel layer (Figure 4-6-B).

- 60 -ft wide geocomposite drainage layer with one 4-inch perforated HDPE pipe in the center with no gravel layer (Figure 4-7). 

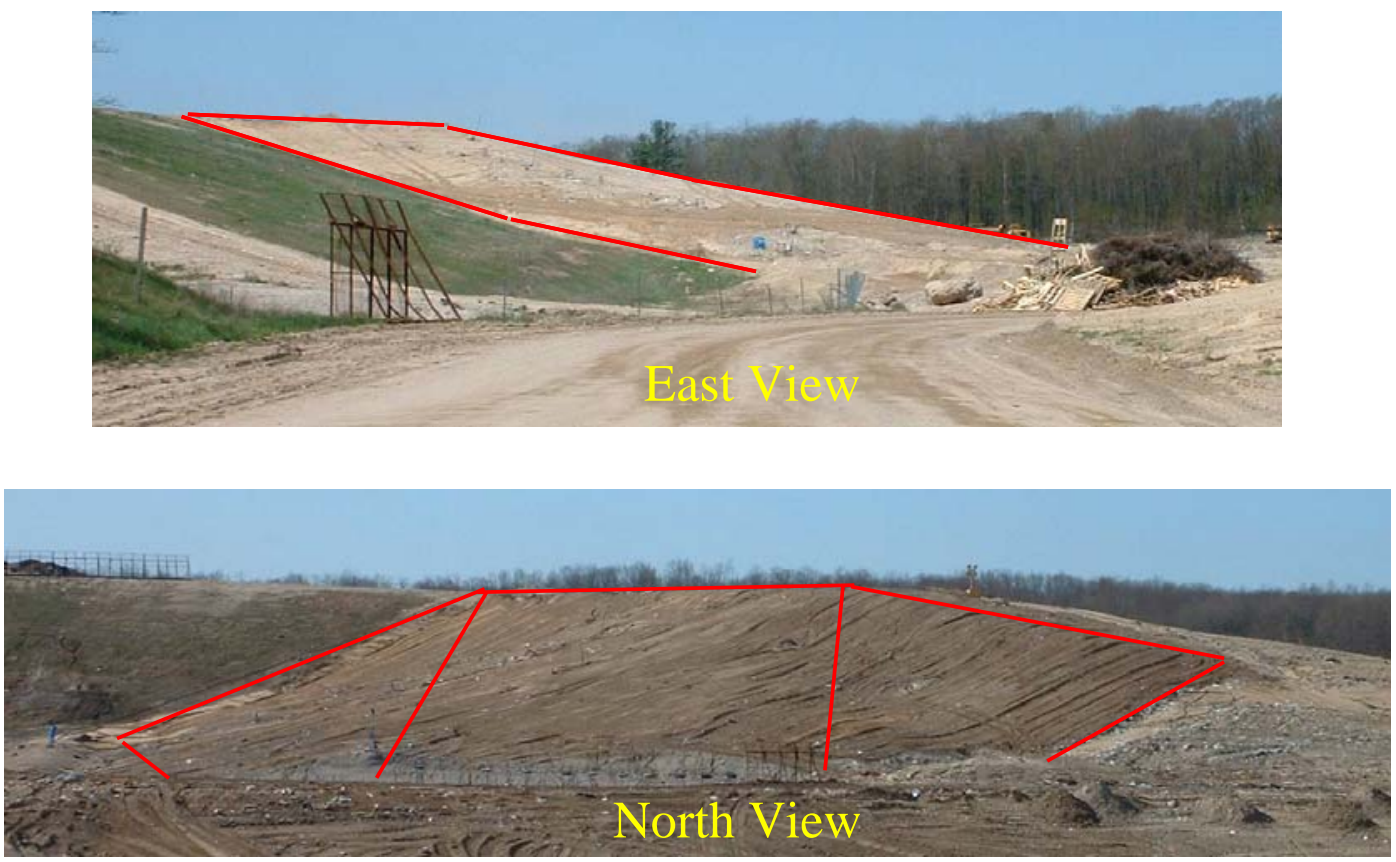

Figure 4-4: Photos of bioreactor landfill cell at NORDF 


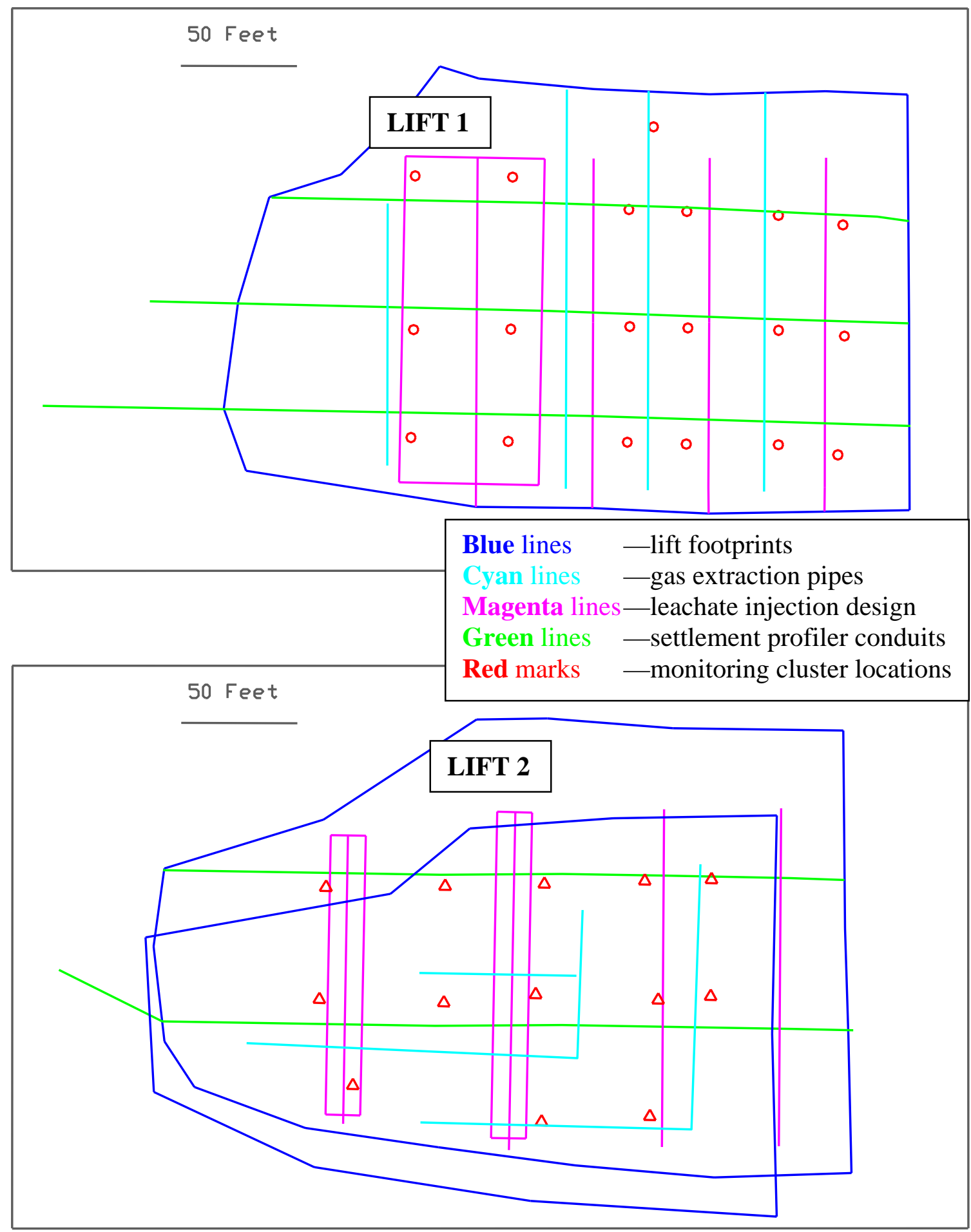

Figure 4-5A: Leachate injection lines, gas extraction lines, and instrument layout for Lifts 1 and 2 


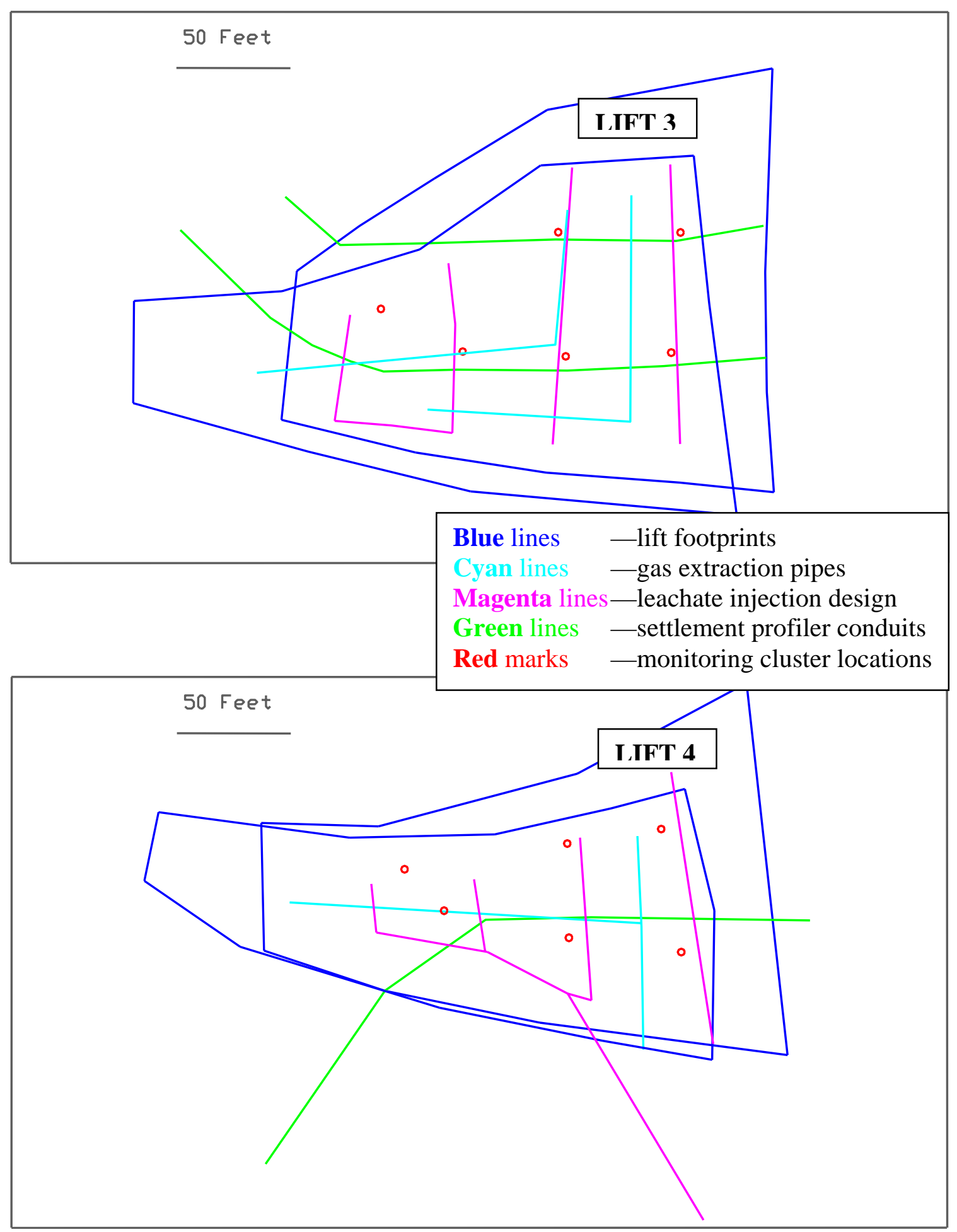

Figure 4-5B: Leachate injection lines, gas extraction lines, and instrument layout for Lifts 3 and 4 


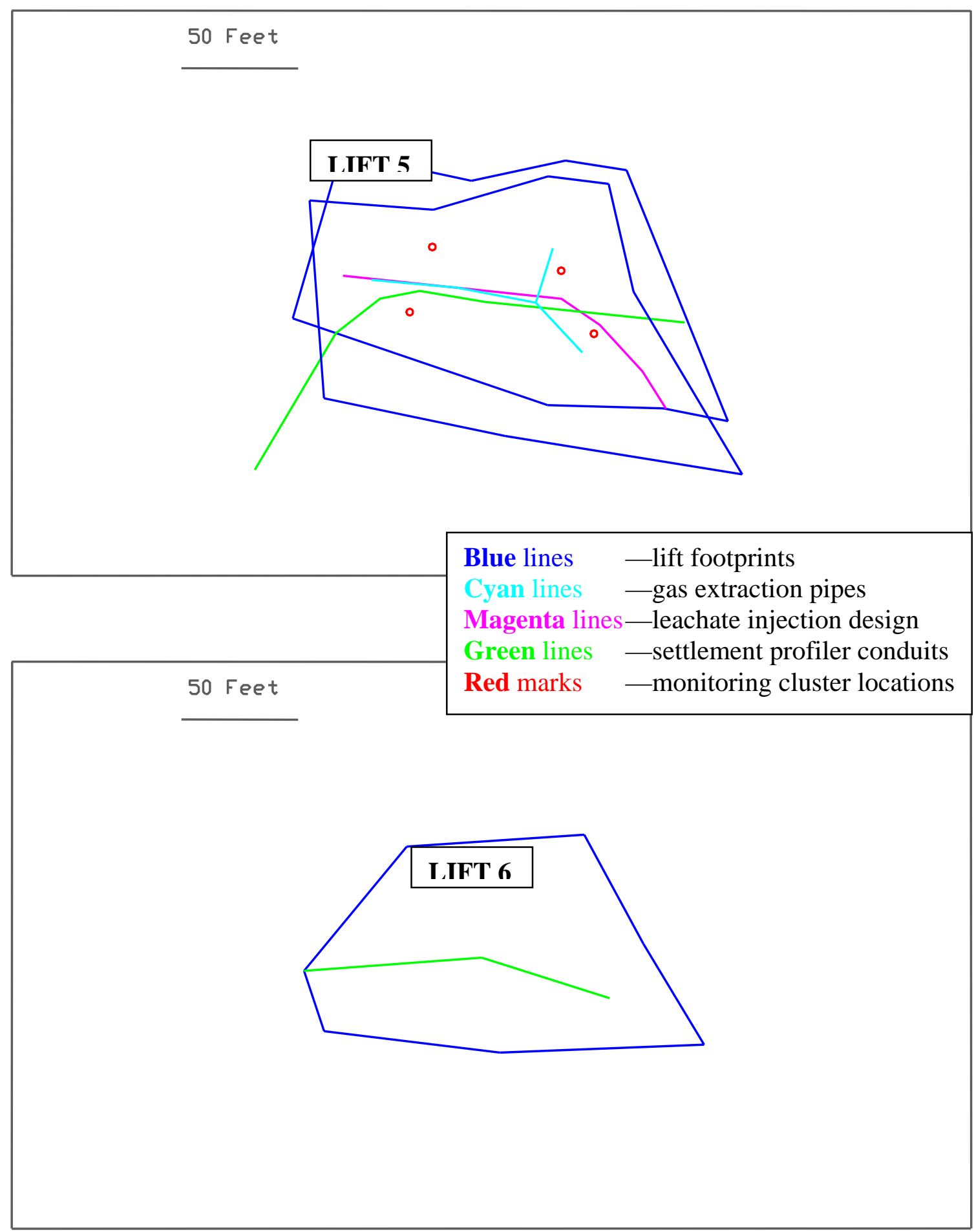

Figure 4-5C: Leachate injection lines, gas extraction lines, and instrument layout for Lifts 5 and 6 


\subsection{Gas Extraction System}

Gas extraction lines (4-inch perforated pipes) were installed horizontally (Figure 4-8-A), in between the leachate recirculation lines in lift 1 . These lines were vertically staggered with respect to the leachate recirculation lines in subsequent lifts. Staggering was introduced as a means for reducing the chance of leachate entry into the gas lines. All gas extraction pipes were connected to a single manifold (Figure 48-B). The gas lines were subsequently (after completion of the cell) connected to a gas extraction system on site. A gas flow meter was installed to record the gas production.

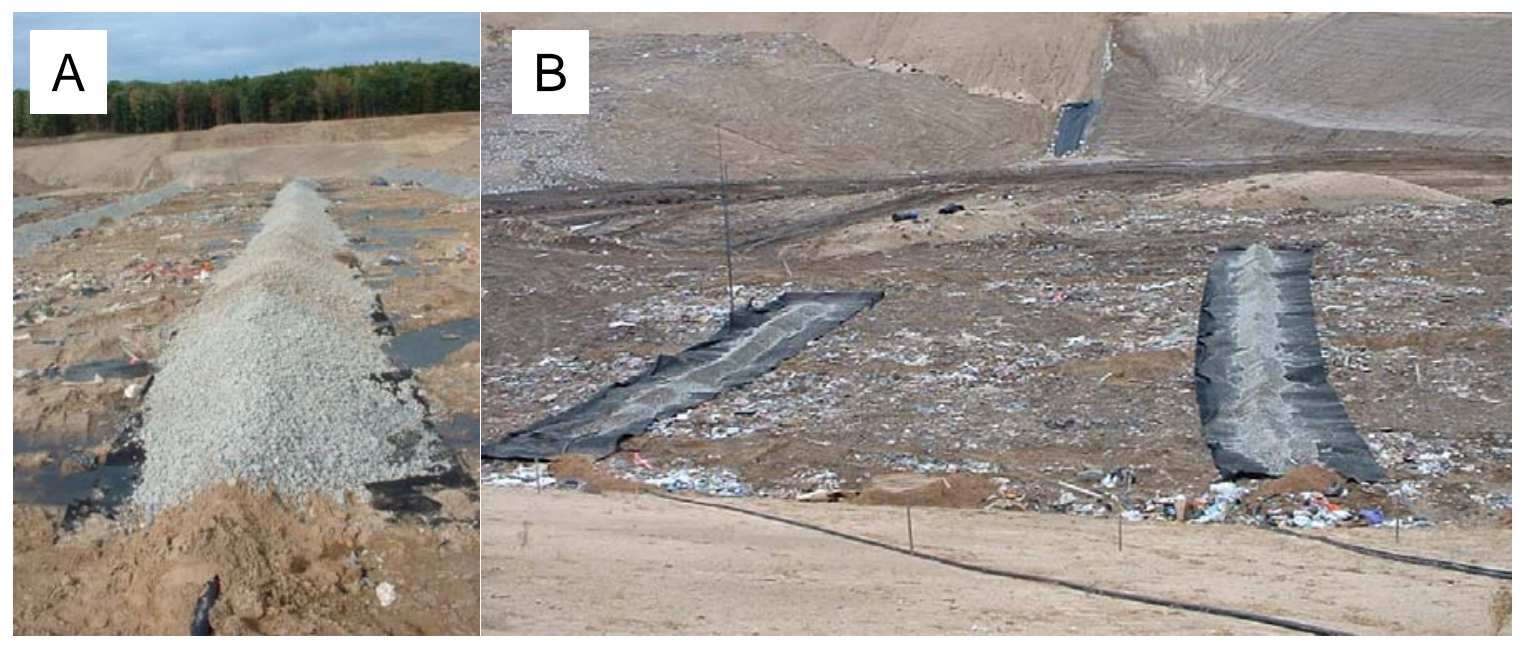

Figure 4-6: Leachate injection line (A) and 15-ft wide geocomposite leachate distribution layer (B)
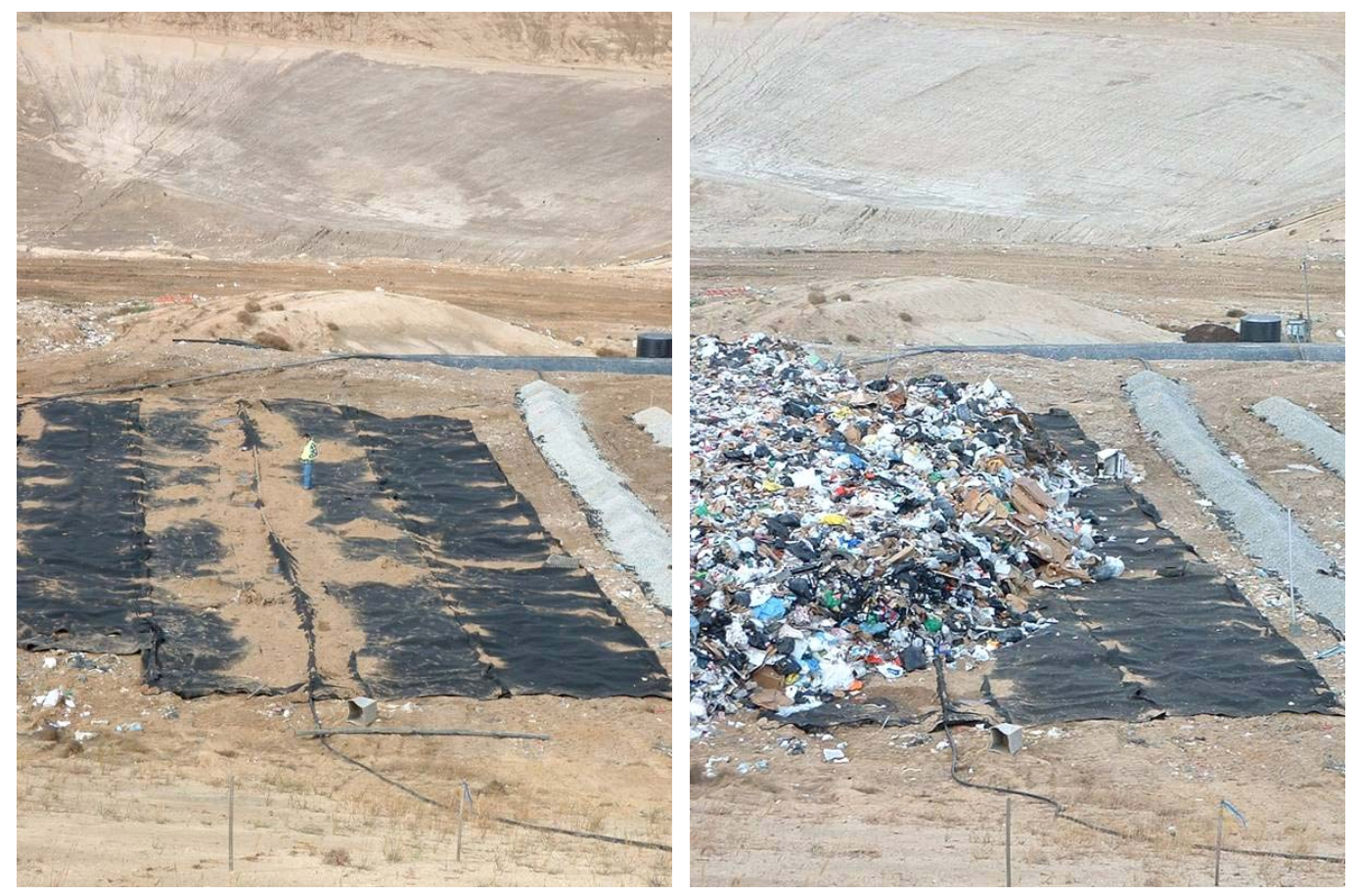

Figure 4-7: 60-ft wide geocomposite leachate distribution layer 

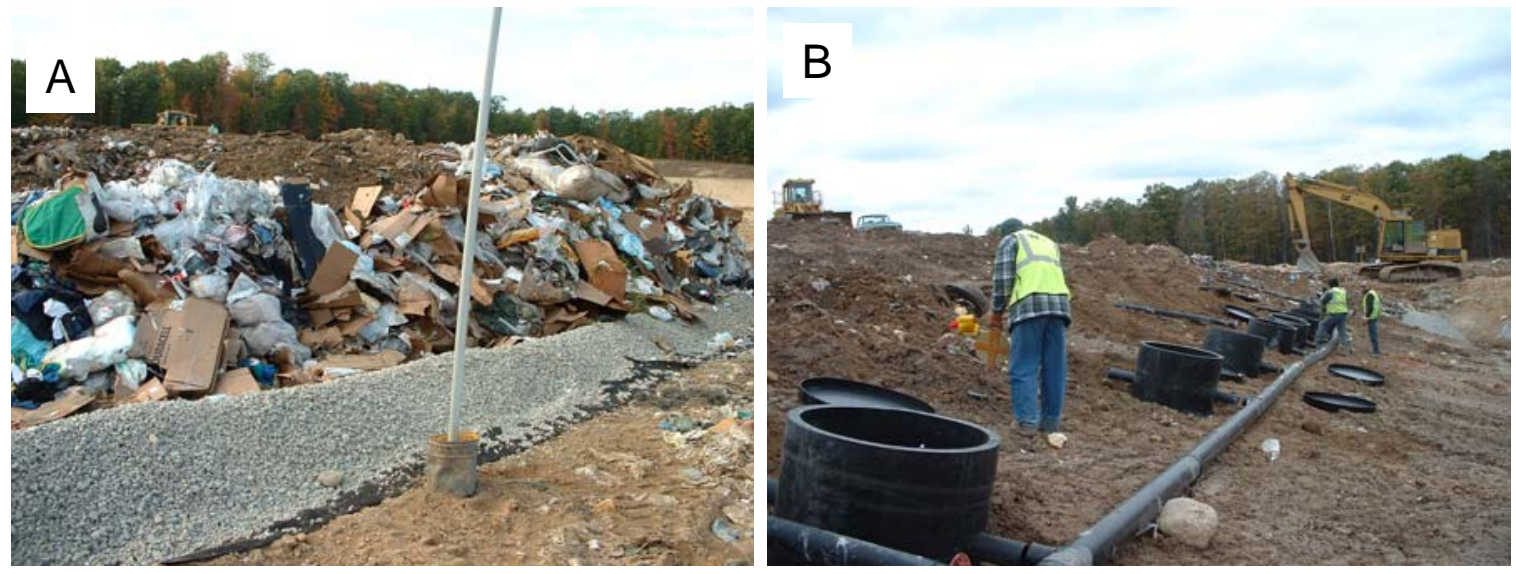

Figure 4-8: Gas extraction line (A) and gas collection manifold (B) 


\section{CHAPTER 5: MONITORING SYSTEM DESIGN}

In order to have an understanding of the factors that affect the performance of the bioreactor landfill cell, a comprehensive monitoring system was designed and implemented. The monitoring system had two major components: on site monitoring system to record the weather-related parameters during whole project period and an in-situ monitoring system. As previously described, the in-situ system included: (i) moisture and temperature monitoring probes, (ii) leachate collection basin, (iii) gas sampling port, and (iv) a settlement profiler. In addition, the amount of leachate injected into this cell and pumped out from the sump was recorded daily. A comprehensive chemical analysis of the leachate sample from the sump was conducted on monthly basis.

Monitoring locations were selected to satisfy the following criteria:

- A monitoring location must represent the system performance and associated heterogeneity; hence, the monitoring grid should be three-dimensional,

- In order to study the relationship between the moisture content, temperature, leachate and gas quality, each monitoring location should have a TDR/temperature probe, leachate sampling basins, and gas sampling ports,

- The vertical interval for the monitoring grid should be 10 feet,

- The location of the monitoring points at each horizontal lift should be related to the leachate recirculation system, thus enabling experimental evaluation of various pumping strategies,

- Settlement conduits should be installed at every 10 -ft vertical interval to provide better resolution.

Based on these design criteria, 48 locations were selected for monitoring the moisture content, leachate and gas compositions (Table 5-1 and Figure 5-1). The labels for all monitoring locations are shown in Figure 5.2. Ten profiler conduits were installed in the cell. They were distributed as follows: 3 in Lift 1, 2 in Lift 2 and 3, 1 in Lift 4, 5, 6.

Table 5-1: Number of monitoring devices installed in the bioreactor landfill cell

\begin{tabular}{cccccc}
\hline $\begin{array}{c}\text { Vertical } \\
\text { From } \\
\text { Bottom }\end{array}$ & Lift & $\begin{array}{c}\text { TDR/Temp } \\
\text { Probe }\end{array}$ & $\begin{array}{c}\text { Leachate } \\
\text { Sampling } \\
\text { Basin }\end{array}$ & $\begin{array}{c}\text { Gas } \\
\text { Sampling } \\
\text { Point }\end{array}$ & $\begin{array}{c}\text { Settlement } \\
\text { Conduit }\end{array}$ \\
\hline $\mathbf{1 0} \mathbf{f t}$ & $\mathbf{1}$ & 19 & 19 & 19 & 3 \\
$\mathbf{2 0} \mathbf{f t}$ & $\mathbf{2}$ & 13 & 13 & 13 & 2 \\
$\mathbf{3 0} \mathbf{f t}$ & $\mathbf{3}$ & 6 & 6 & 6 & 2 \\
$\mathbf{4 0} \mathbf{f t}$ & $\mathbf{4}$ & 6 & 6 & 6 & 1 \\
$\mathbf{5 0} \mathbf{f t}$ & $\mathbf{5}$ & 4 & 4 & 4 & 1 \\
$\mathbf{6 0} \mathbf{f t}$ & $\mathbf{6}$ & & & & 1 \\
\hline
\end{tabular}




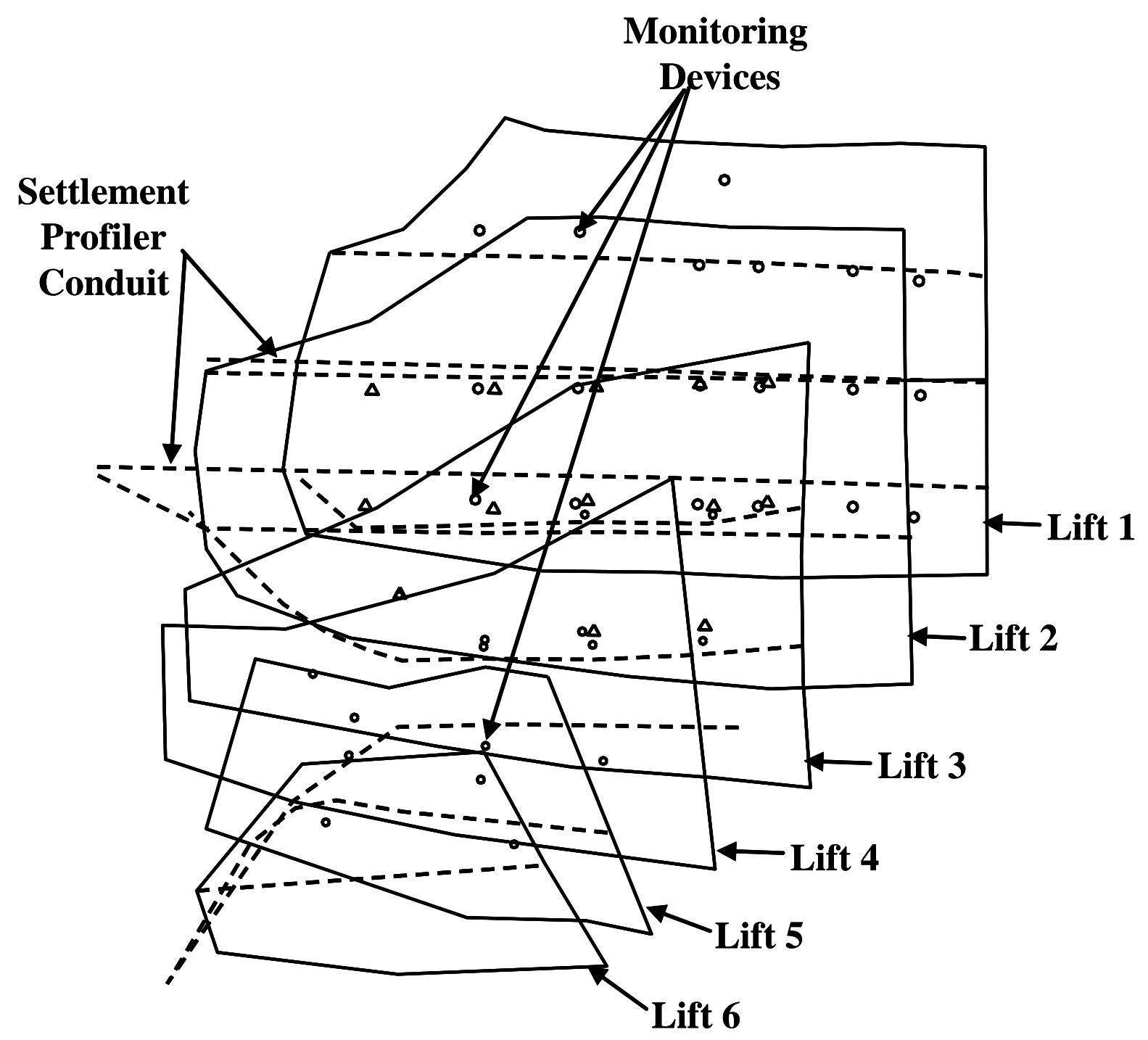

Figure 5-1: The layout of monitoring locations 


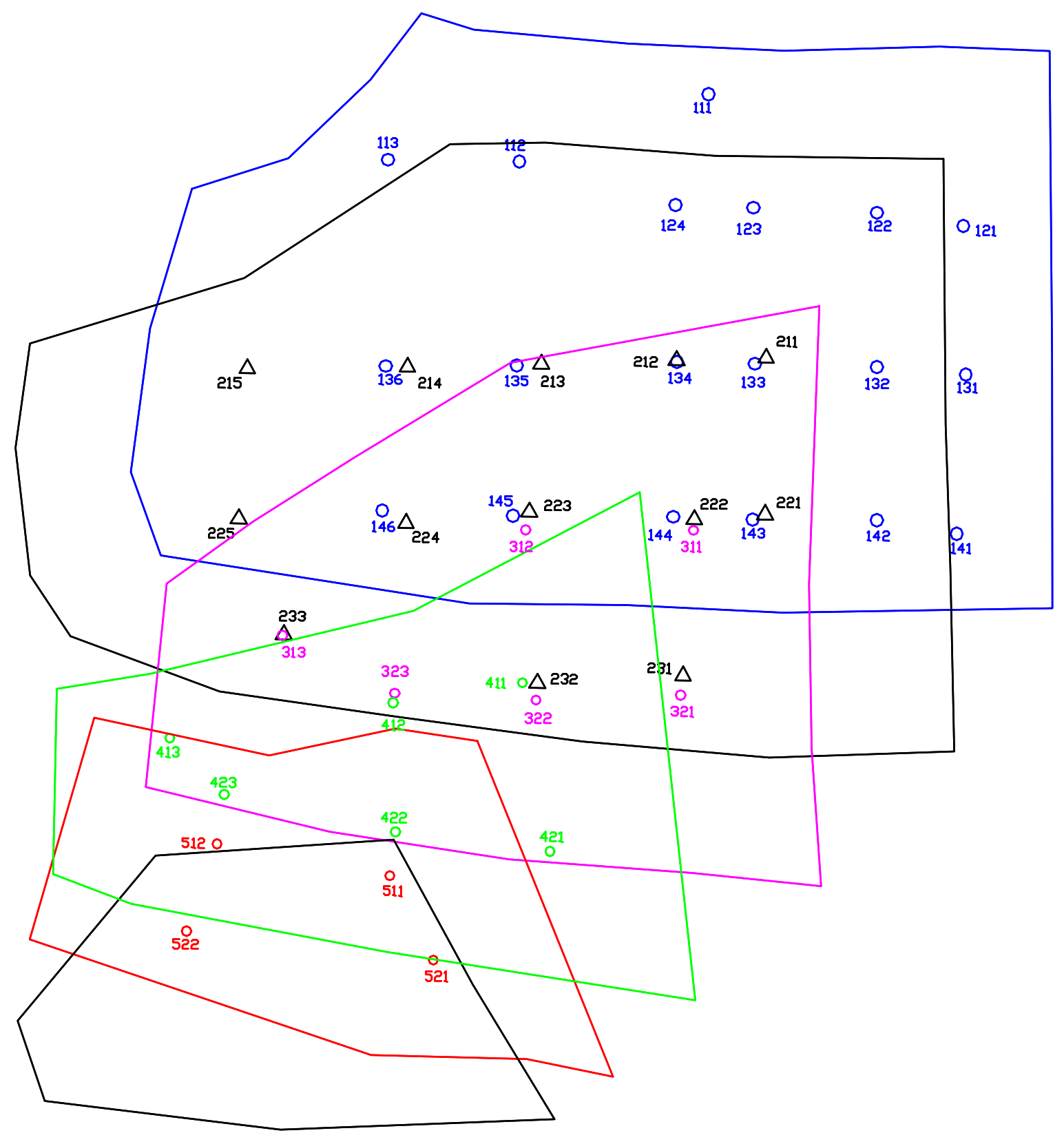

Figure 5-2: The labels for monitoring device locations 


\section{CHAPTER 6: INSTALLATION OF MONITORING SYSTEM}

\subsection{Weather Station}

A full function weather station was installed outside of the northeast corner of the landfill cell (Figure 6-1). It was placed on non-disturbed ground to provide better stability. It was located away from the landfill slope to reduce the effect localized wind draft, but close to the landfill cell to reflect local weather conditions. Seven parameters were recorded: air temperature, humidity, wind speed and direction, precipitation (rain and snow), solar radiation and soil temperature. In addition, the data logger of the weather station also served as the logging device for in-situ moisture and temperature sensors.

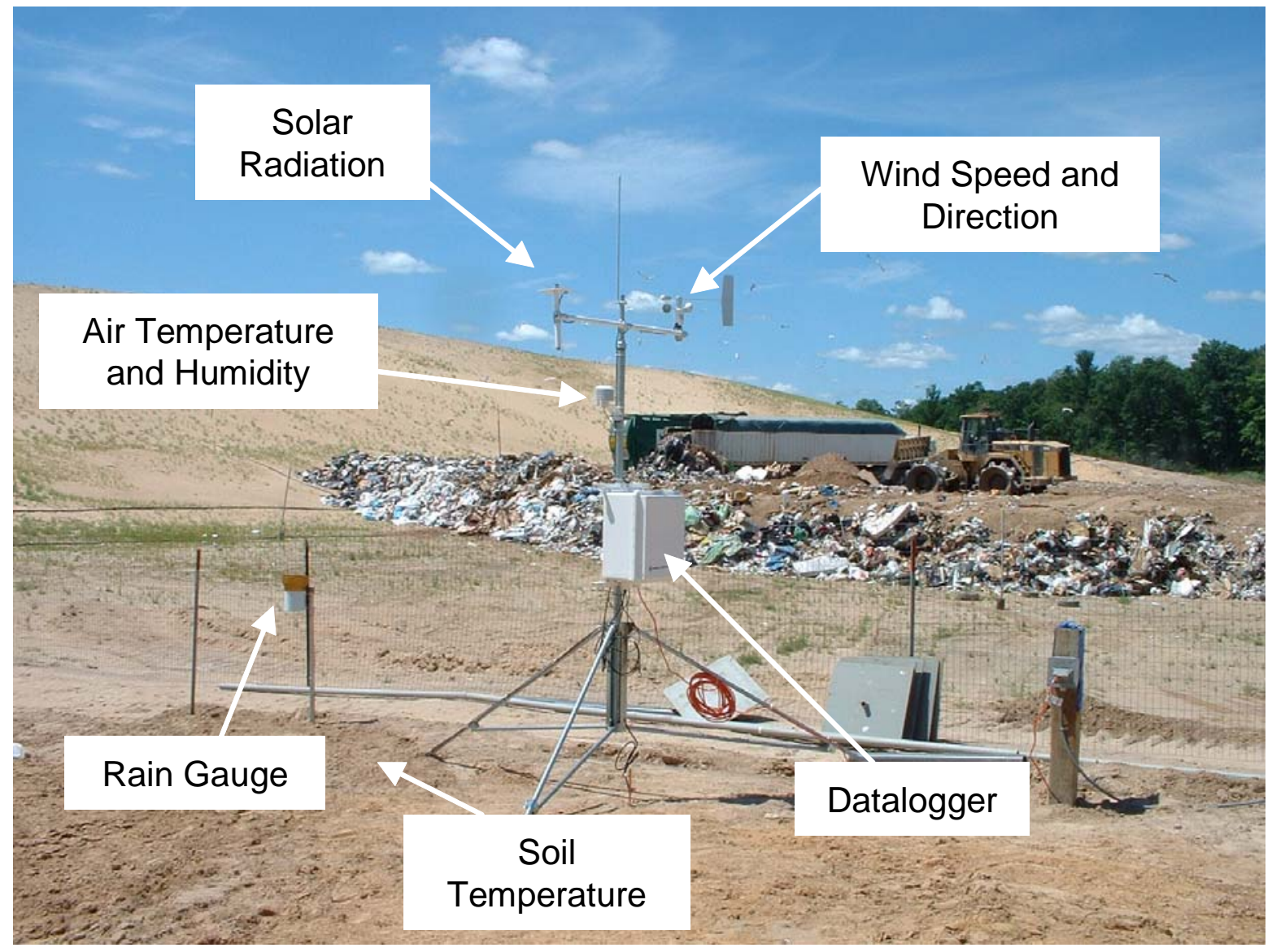

Figure 6-1: Weather station and data logger

\subsection{In-situ Monitoring Devices}

Each sampling location included a moisture and temperature probe, a leachate collection basin, and a gas sampling port. Landfilling practices and the nature of MSW made installation a rather challenging task. The major question was how to protect the monitoring equipment from physical damage during the MSW and filling process and insure that the devices have direct contact with the surrounding MSW. The following approach was adopted to protect various components of the monitoring system. 
1. The cluster location was identified on the surface of the lift using electronic surveying equipment.

2. An excavator was used to dig a 3 and 6 feet deep pit (Figure 6-2-A).

3. Instruments were placed in the waste in areas of the pit void of sharp edged MSW (Figure 6-2-B).

4. Signal wires and sampling tubes were strung out of the pit to the surface (leaving 2-3 $\mathrm{ft}$ of slack).

5. Vulnerable portions of instrumentation were shielded with non-edged MSW (Figure 6-2-C).

6. An excavator backfilled the pit-burying the instrumentation (Figure 6-2-D).

7. Cables and sampling tubes associated with each cluster were routed through a HDPE conduit extending from the cluster location to the outside of the cell.

After each lift was filled, the installation of the monitoring devices was initiated. The probe/sample clusters were installed at depths ranging from 3 to 6 feet below grade. An excavator was used to dig to the installation depths because hand digging was extremely slow and cumbersome. This "subgrade installation" methodology was designed to protect the cluster from damage that could take place during compaction of the lift that followed. The surrounding compacted MSW could bear most of the vertical stress applied during compaction - thus protecting the cluster. The instrument signal wires and sampling tubes were installed with approximately 2 to 3 feet of extra slack length. Providing this slack could decrease the chance that local differential settlement of the MSW would cause detrimental effects. The signal wires, sampling tubes, and instruments placed in the MSW relatively free of sharp edged articles (sharp glass, edged metal, broken lumber, etc.). Remaining MSW (cardboard, paper, soft plastic or cloth) served as protection for especially vulnerable instruments. This was considered a somewhat better alternative to filling with sand used in other studies. All cables for moisture and temperature probes and sampling tubes for leachate and gas sampling ports were routed through 2" HDPE conduits extending outside the east side of the cell to provide extra protection (Figure 6-3-A and B). The conduits were covered with 6 to 12 inches of cover soil for further protection (Figure 6-3-C and D).

The TDR/temperature sensor was placed directly at the bottom of the excavated hole and covered with "soft" MSW such as paper, textile, and soft plastic object. The leachate collection basin was buried at the bottom of the hole. Washed gravel was placed on the basin before placing MSW on top (Figure 64). The gas sampling port was covered with two liters of washed gravel at bottom of the hole (Figure 6-5).

The settlement profiler conduits were installed on the surface of each lift. Three-inch HDPE tubing was used as the conduit (Figure 6-6). The conduit was placed in a trench (2-3 ft in depth) and refilled with a mixture of MSW and cover soil. Both ends of the conduit were extended to the outside of the landfill cell. 

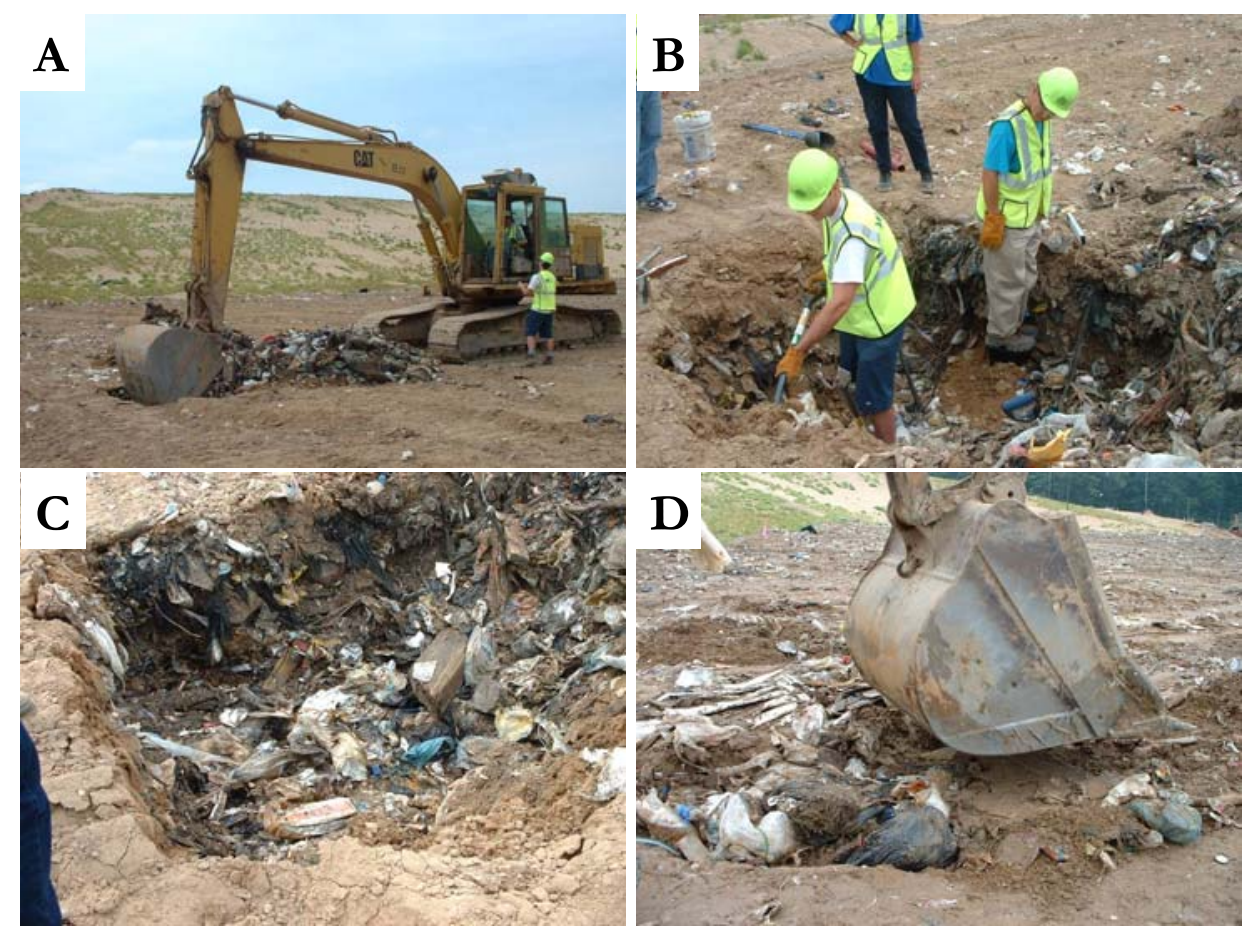

Figure 6-2: Placement of in-situ monitoring instruments at selected locations
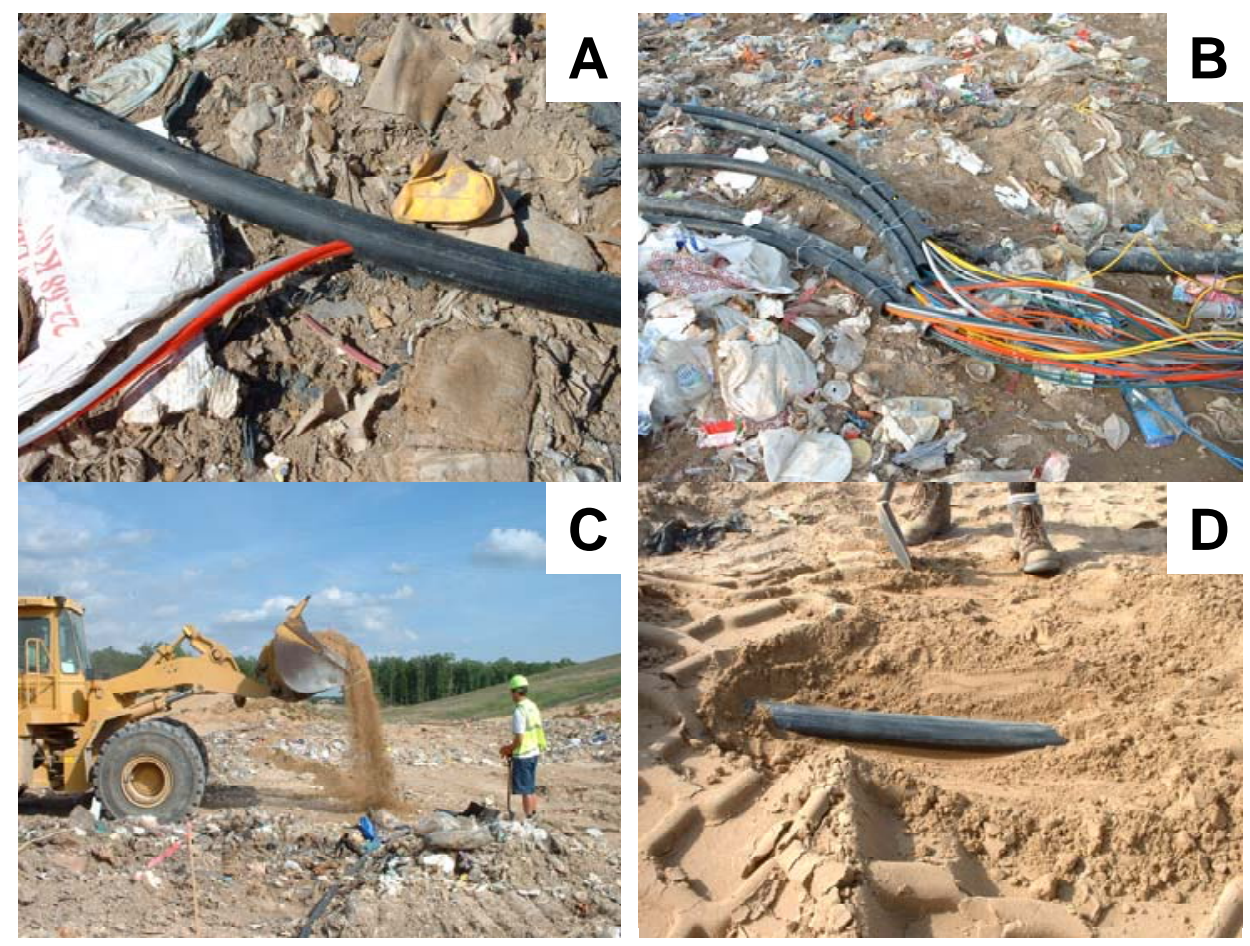

Figure 6-3: Placement of conduits for signal cables and sampling tubes 

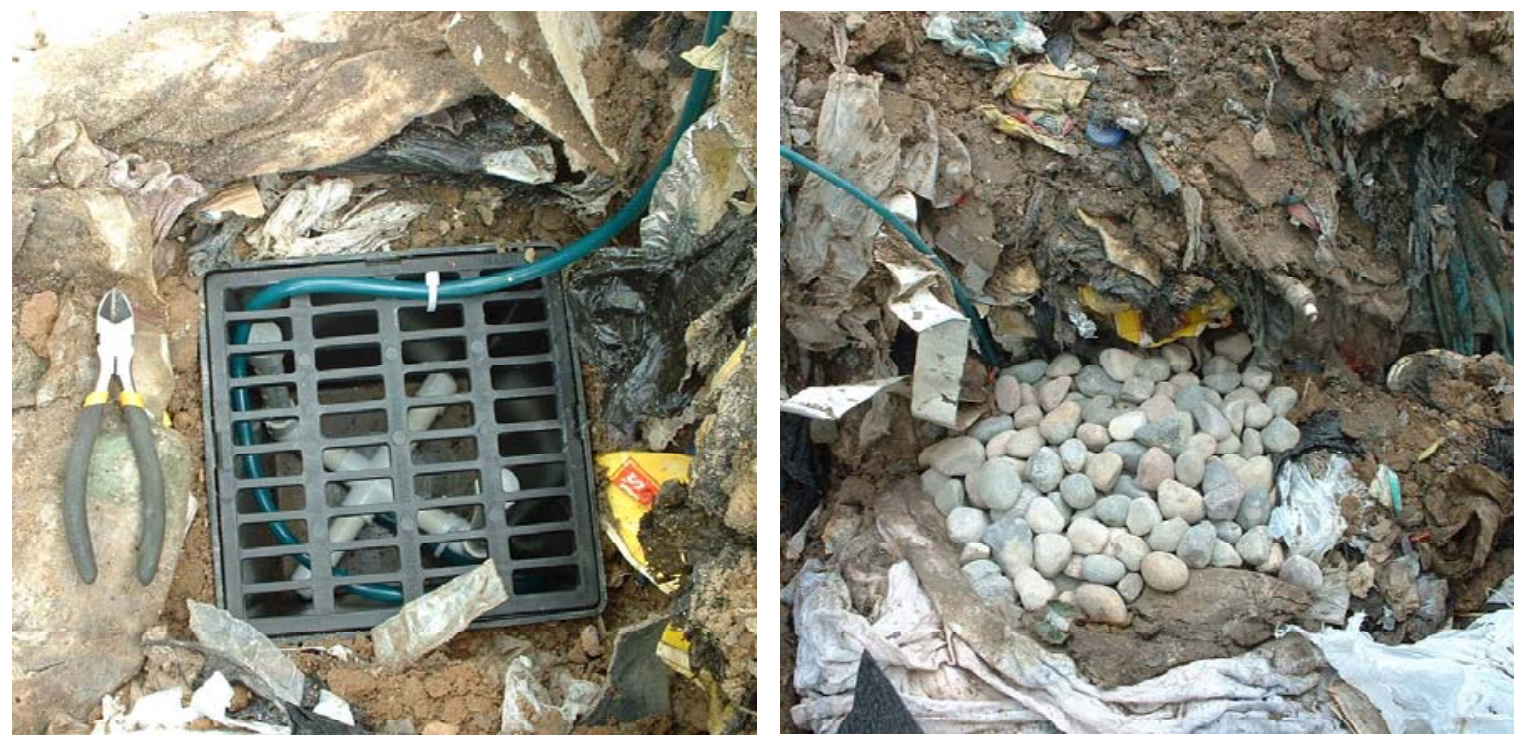

Figure 6-4: Installation of the leachate collection basin
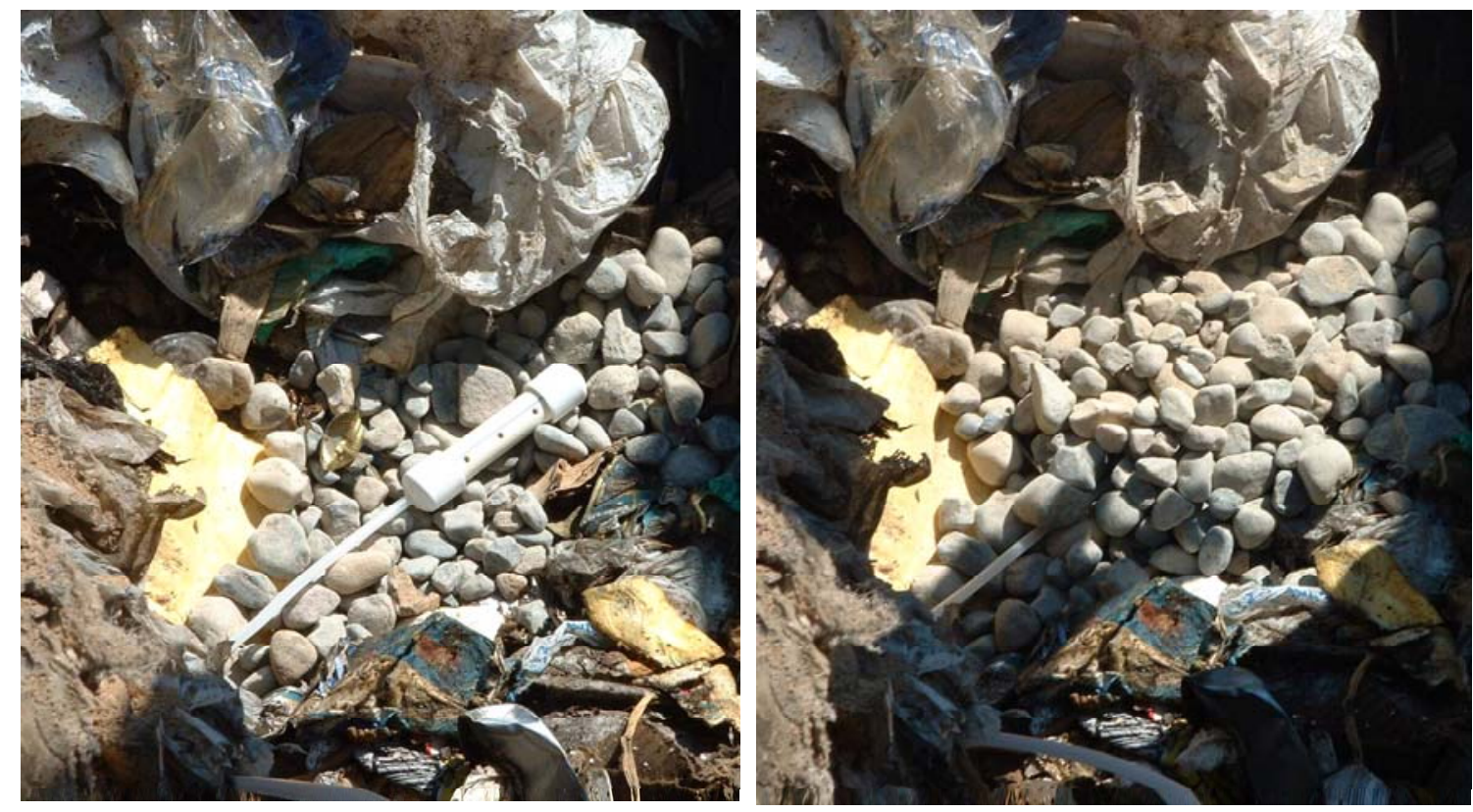

Figure 6-5: Installation of the gas sampling port 


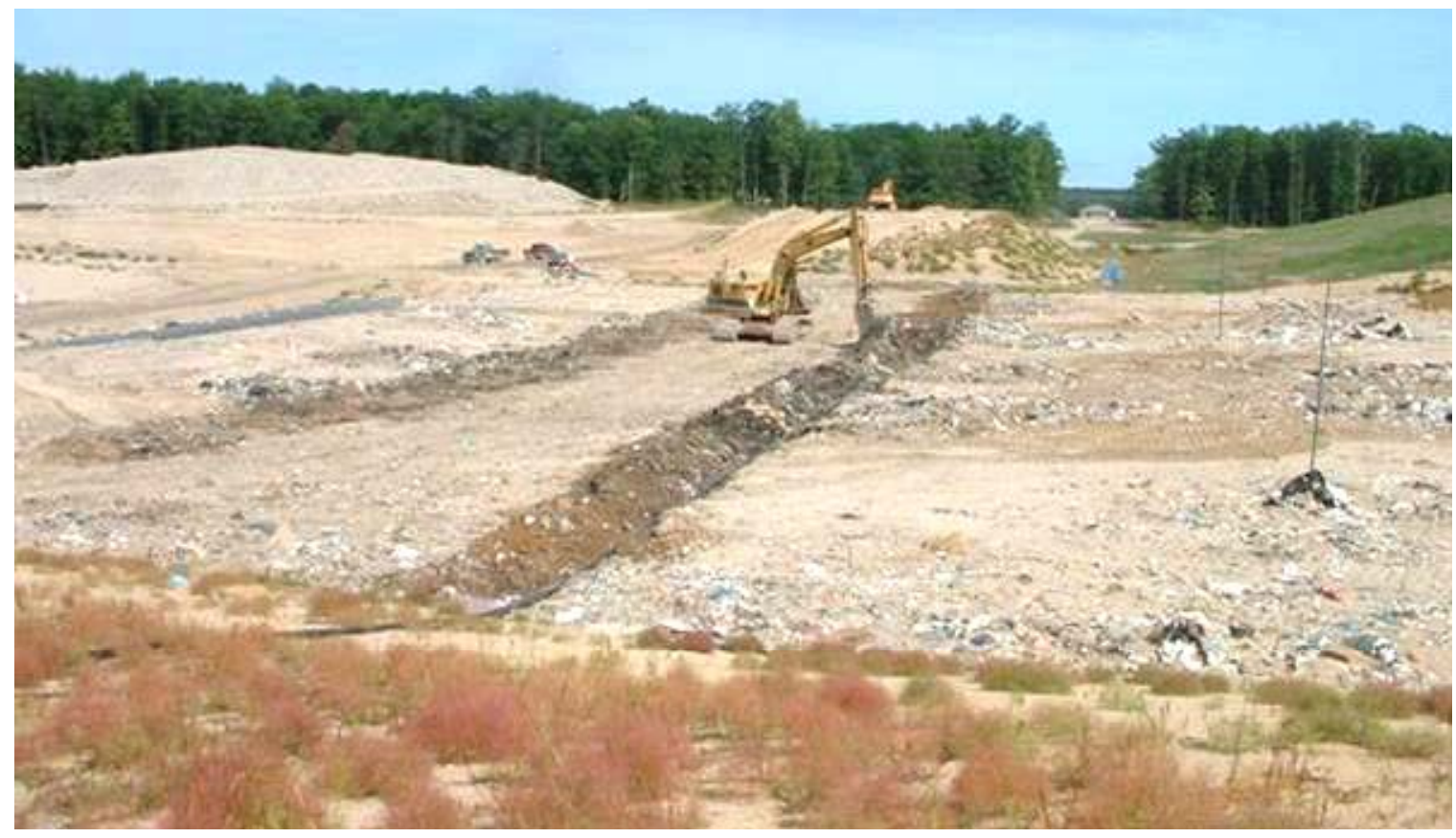

Figure 6-6: Installation of settlement profiler conduits 


\section{CHAPTER 7: BIOREACTOR LANDFILL CELL: START-UP PHASE}

\subsection{Water Balance}

To evaluate the overall moisture level in the bioreactor landfill, a water balance calculation was performed. There were three sources of moisture: initial moisture content of the MSW, precipitation during the filling operation, and leachate injection during and after the filling operation. The initial moisture content of the MSW was assumed to be 25\% (wet basis) based on data provided by Waste Management Inc. Rain and snow were recorded by a rain gauge installed on site. The volume of water import was calculated based on the area of the landfill cell. During the filling of each lift, leachate was applied on the working surface and site operator recorded the volume on a daily basis. After the leachate recirculation pipe was covered by the MSW, leachate was injected at a rate of $13.3 \mathrm{gal} / \mathrm{ft}$-day, twice a day during the operation days (5 days/week). The volume of the leachate injected was recorded daily. For this preliminary calculation, evaporation was not considered.

In Figure 7-1, the "Total Water In" is the sum of initial amount of water in waste, precipitation, leachate addition on the working surface and leachate injection using leachate recirculation pipes. The "Leachate Out" represents the leachate volume collected in the sump. The "Water Storage" was the difference between "Total Water In" and "Leachate Out". After the first lift filled, the filling was suspended for two months (summer of 2002), due to the permit modification. There were a few heavy rain events and the average water content increased significantly (Figure 7-1). As the filling resumed, the average water content in MSW was reduced due to addition of drier MSW. With filling of fresh MSW, leachate injection also resumed. The average water content remained at approximately $35 \%(\mathrm{w} / \mathrm{w})$. The leachate injection ratio (leachate volume injected to compacted volume of the MSW) in first three lifts

was between 26 and 30 gal/yard ${ }^{3}$ (Figure 7-2). Due to the cold weather conditions, the leachate injection was stopped during winter. Smaller amount of leachate was injected into Lift 4 and 5 . No leachate was injected into Lift 6 before June 20, 2003.

By June 20, 2003 (when the cap was installed), a total of 4.1 million gallon of water entered the cell, and 1.9 million gallons of leachate was collected from the sump (Figure 7-3). Thus, 2.2 million gallons of leachate was retained in cell. 


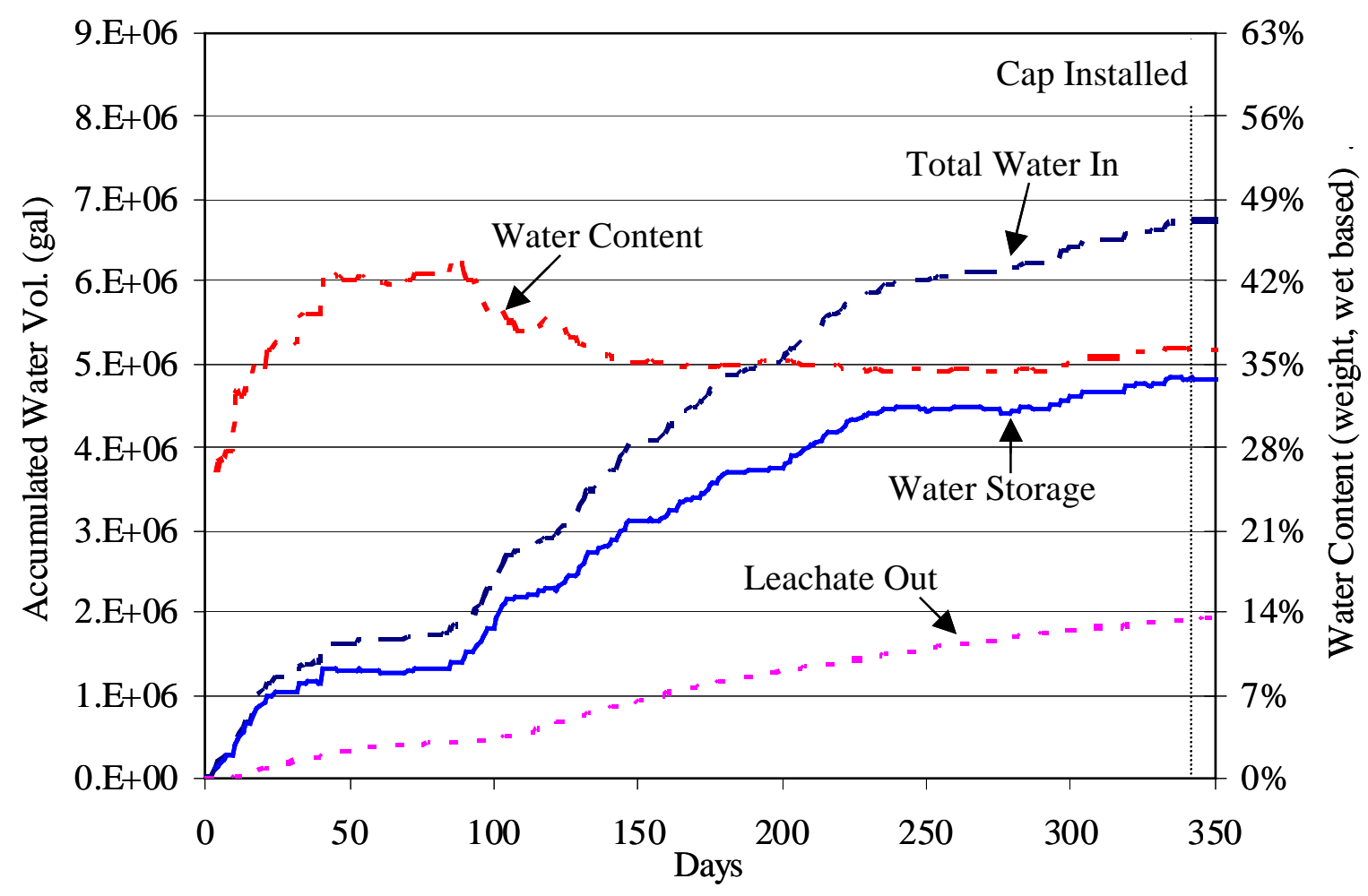

- - Total In - - - - Leachate Out — Storage - - - \% Water

Figure 7-1: Water balance in bioreactor landfill

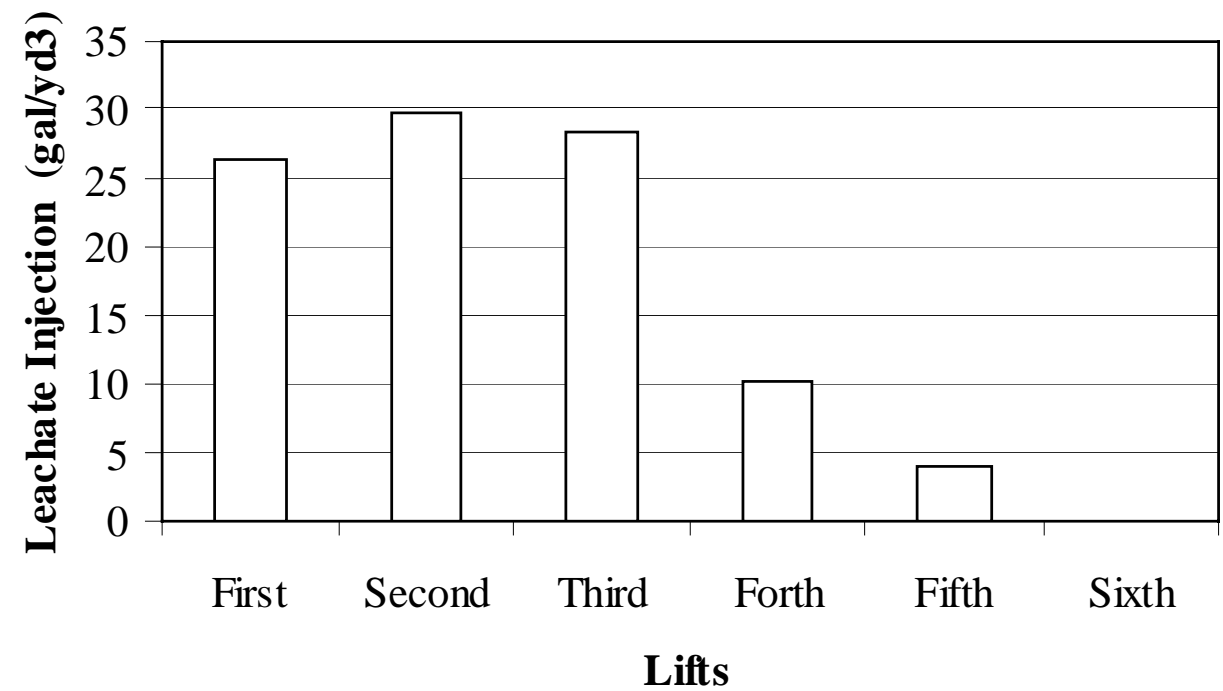

Figure 7-2: Leachate injection in each lift 


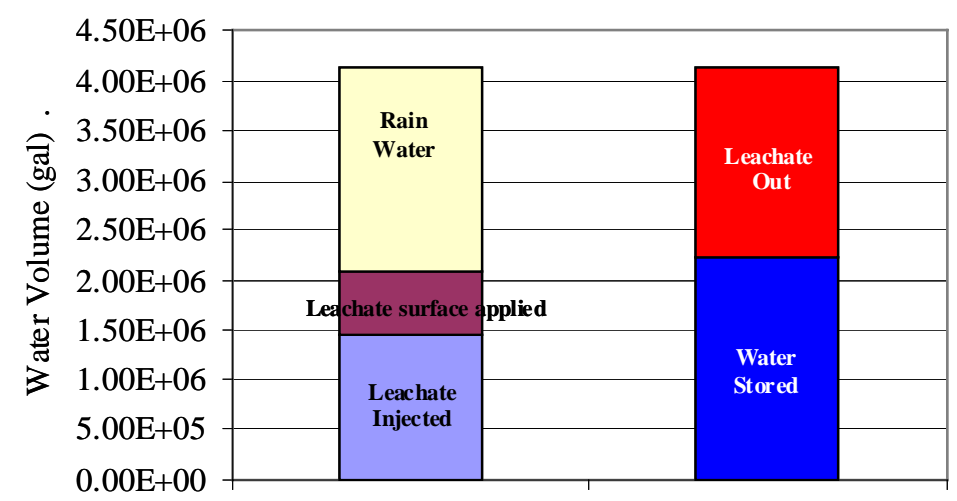

Figure 7-3: Summary of water balance results

\subsection{Moisture Distribution in the Bioreactor Landfill}

Moisture content was monitored over time at all the 48 locations by the TDR probes placed in the waste (Figure 7-4 to 7-8). To reduce the variability between the probes, the volumetric moisture content was calculated by dividing the recorded signal from the probe with the signal obtained at $100 \%$ volumetric content (merging the probe in waster). Moreover, the moisture content was adjusted based on the calibration curve (Figure 3-6). 




Figure 7-4: The volumetric moisture content (black lines) and temperature (red lines) in Lift 1 


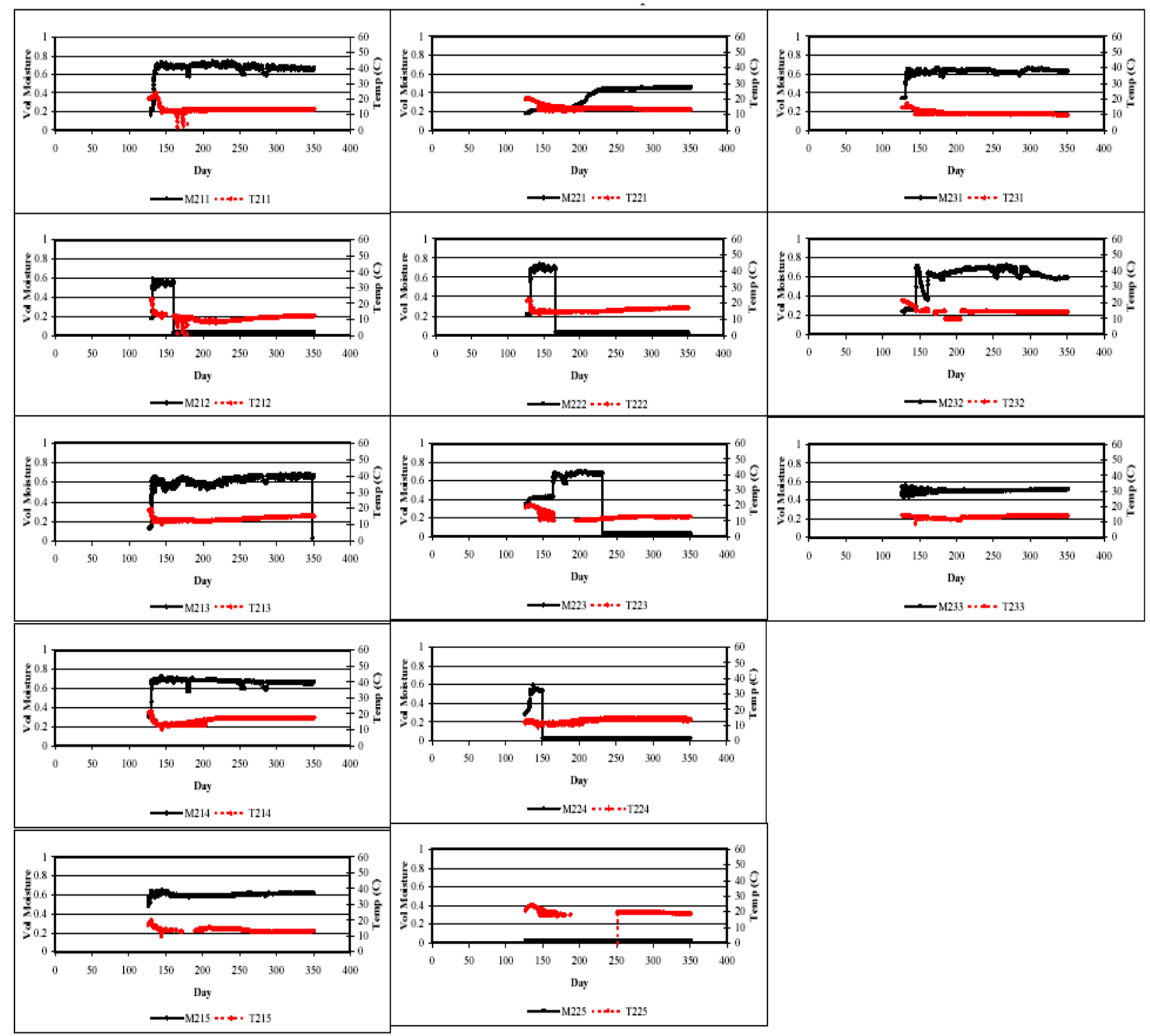

Figure 7-5: The volumetric moisture content (black lines) and temperature (red lines) in Lift 2 


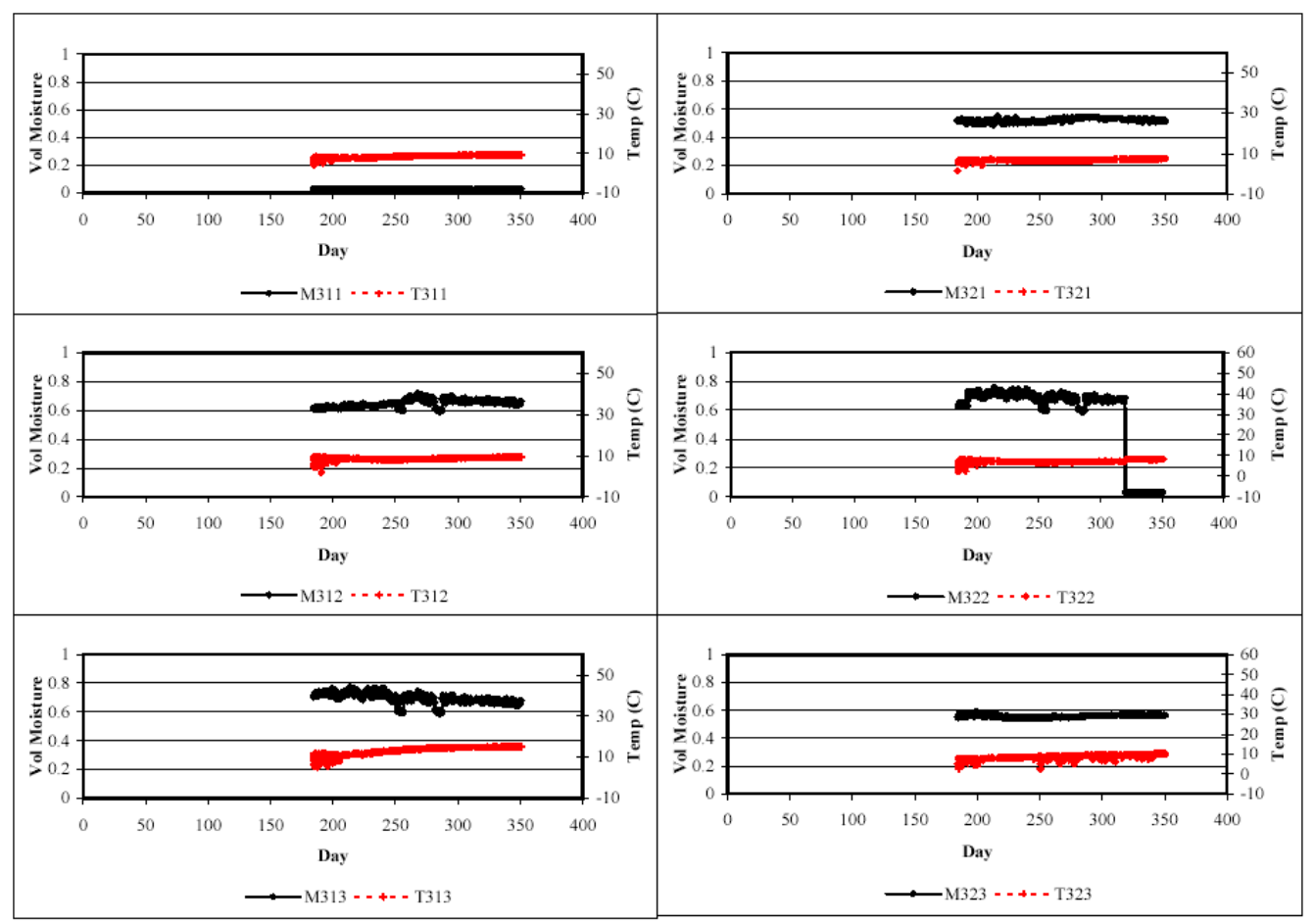

Figure 7-6: The volumetric moisture content (black lines) and temperature (red lines) in Lift 3

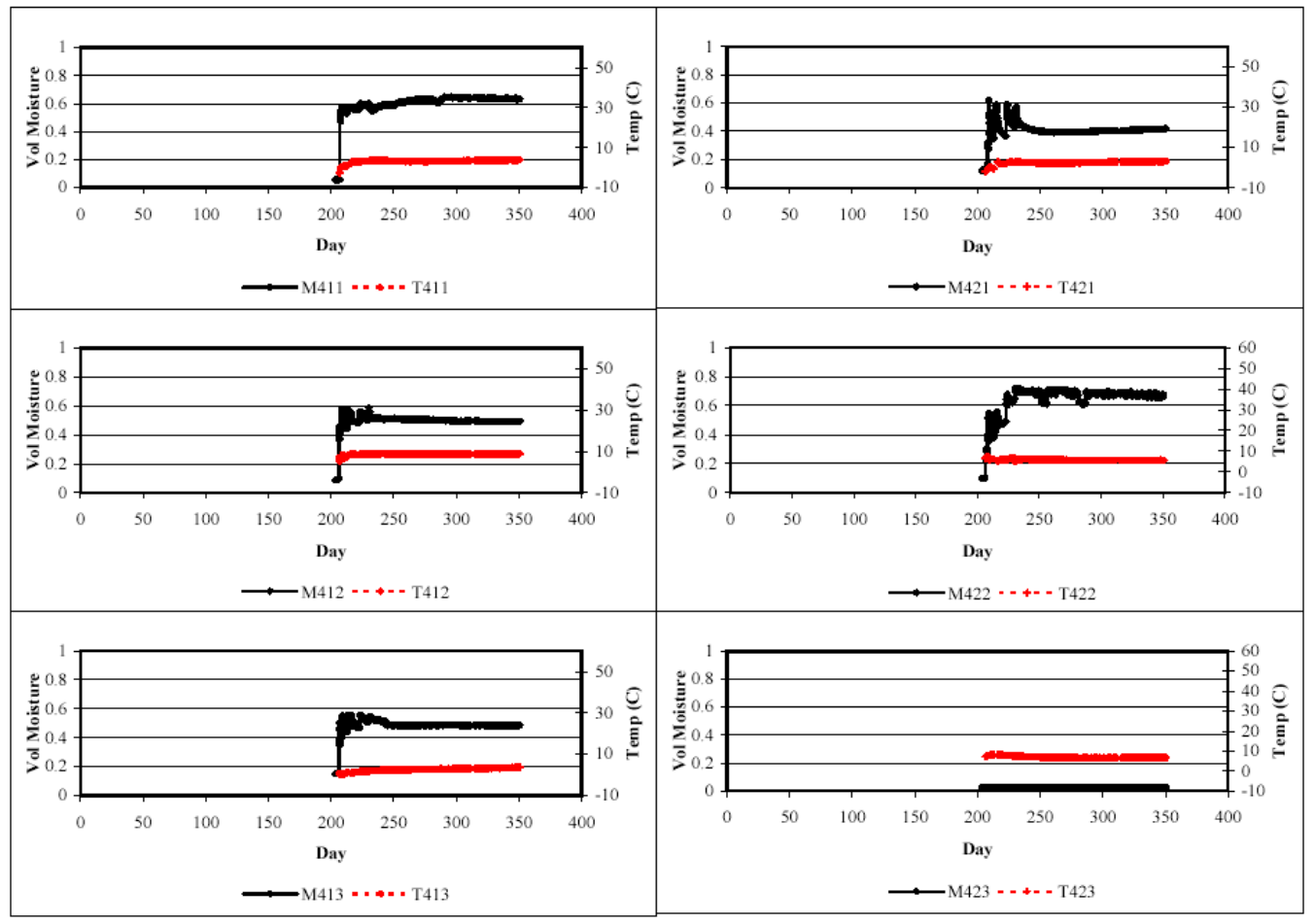

Figure 7-7: The volumetric moisture content (black lines) and temperature (red lines) in Lift 4 


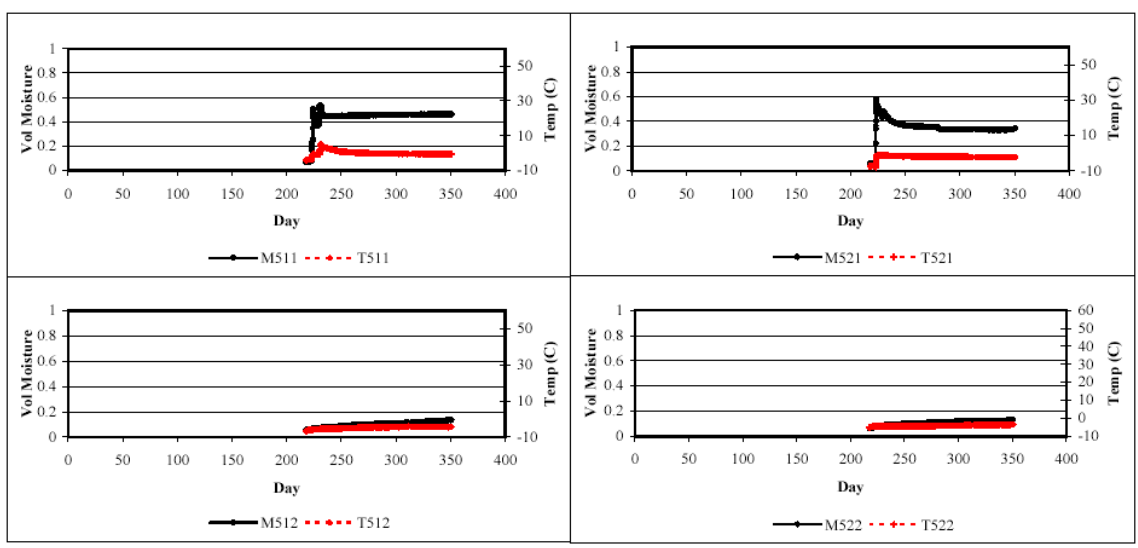

Figure 7-8: The volumetric moisture content (black lines) and temperature (red lines) in Lift 5

The average, minimum, and maximum moisture content in the bioreactor is plotted in Figure 79A. Due to the large number of probe installed in Lift 1 and 2, the overall average moisture content was controlled by the moisture content in the first two lifts. The average moisture content reached approximately $50 \%$ and decreased once additional lifts were in place. The maximum moisture content reached to about $70 \%$. The average moisture content in each lift and accumulated precipitation values are plotted in Figure 7-9B.

Lift 1 was filled between late spring and early summer of 2002, which are "wet" months in Michigan. Therefore, the initial moisture content in the first lift was high compared to the lifts that followed (Figure 7-9B). The lowest initial moisture content was found in Lift 5, which was filled later in winter month. After the completion of Lift 1, the filling was stopped for permit modification. This lift was not covered with any geo-membrane for approximately two months. Hence, the moisture increased due to precipitation. Because the subsequent lifts were filled in "dry" months, the moisture content in these lifts was not affected by precipitation. After leachate injection, the moisture did increase sharply, as expected (Figure 7-9B). The average moisture content was similar in all lifts except in Lift 5 for which leachate injection was limited due to freezing conditions. The moisture content was not affected by precipitation during the "wet" months that followed during spring. This is because the waste had been covered with an intermediate soil layer and most of the precipitation was removed as surface runoff. Infiltration was very small compared to the leachate injection. 

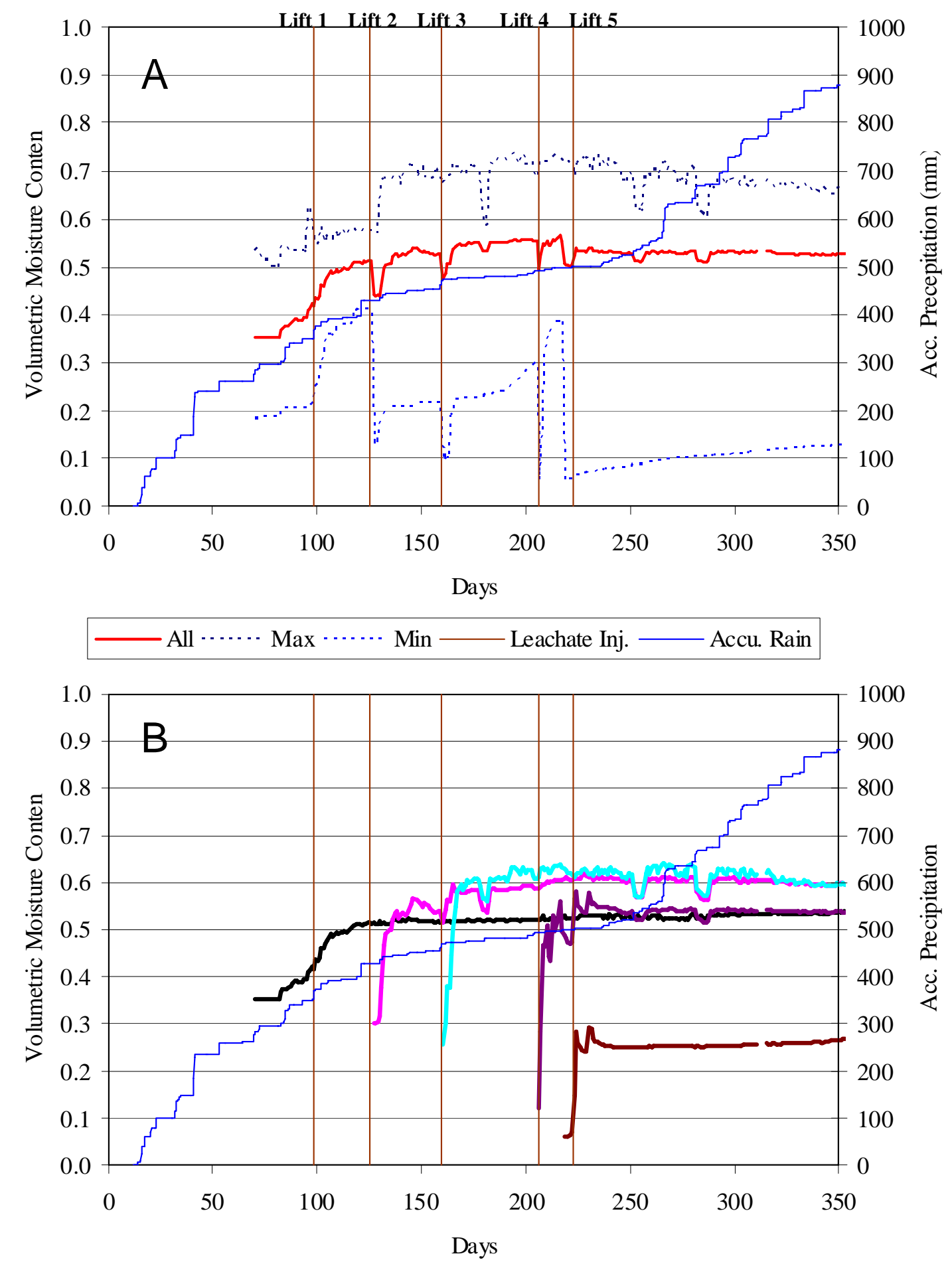

Lift $1-$ Lift $2-$ Lift $3-$ Lift $4-$ Lift $5-$ Leachate Inj. — Accu. Rain

Figure 7-9: The volumetric moisture content and cumulative precipitation in the bioreactor landfill cell. A: Average, maximum and minimum volumetric moisture content and accumulative precipitation; B: Average volumetric moisture content in each lift and accumulative precipitation. 
To improve the decomposition rate of waste, the moisture content of the waste had to be increased to about 35\%. This was accomplished by using three different types of leachate recirculation systems: i) horizontal pipes, ii) a 15-ft wide geocomposite drainage layer, and iii) a 60-ft wide geocomposite drainage layer (Figure 4-5 and 4-6). All recirculation systems were laid on top of the compacted waste. Moisture content data at locations closer to the leachate pipes in Lift 1 and 2 were selected for this study. A typical TDR response to leachate injection is shown in Figure 7-10. A sharp increase of the TDR response (located $5 \mathrm{ft}$ below and $5 \mathrm{ft}$ aside) was observed after several leachate injection events (Figure 710). Temperature always dropped after each injection in response to the waterfront passing through the sensor locations. The arrival time of this waterfront was calculated based on the start of injection and the start of TDR increases. However, in some cases, leachate was pumped into several pipes at very close intervals. In some cases, the TDR response corresponded to more than one recirculation pipe (e.g., in Figure 7-10, two leachate pipes 5 and 60 feet apart). In those cases, we assumed that the leachate from the closest pipe caused the increases in the TDR responses. The leachate arrival time vs. the distances between the TDR sensor and leachate pipes is plotted in Figure 7-11. All the sensors were 5 feet below the corresponding leachate pipes. The leachate was able to reach the TDR sensor 10 feet away within 3 hours. Even at the sensor that was 42 feet away, leachate front arrived within 2 to 9 hours. There were no significant differences between the three types of leachate recirculation pipe designs.

Since all the leachate recirculation pipes were laid on top of the compacted lifts, compaction of waste directly above the pipes was somewhat limited. This is because compaction directly above the pipes was practiced only after depositing 5 feet of MSW. It is possible that a low compaction layer formed around the recirculation pipes. The difference in hydraulic conductivity below the pipe and in the low compaction layer could facilitate the lateral movement of the leachate after each pulse injection (20 minutes duration). As a result, differences between the injection system designs would be less important. Placement of recirculation pipes on the compacted lift improved the uniform distribution of water in the waste. 


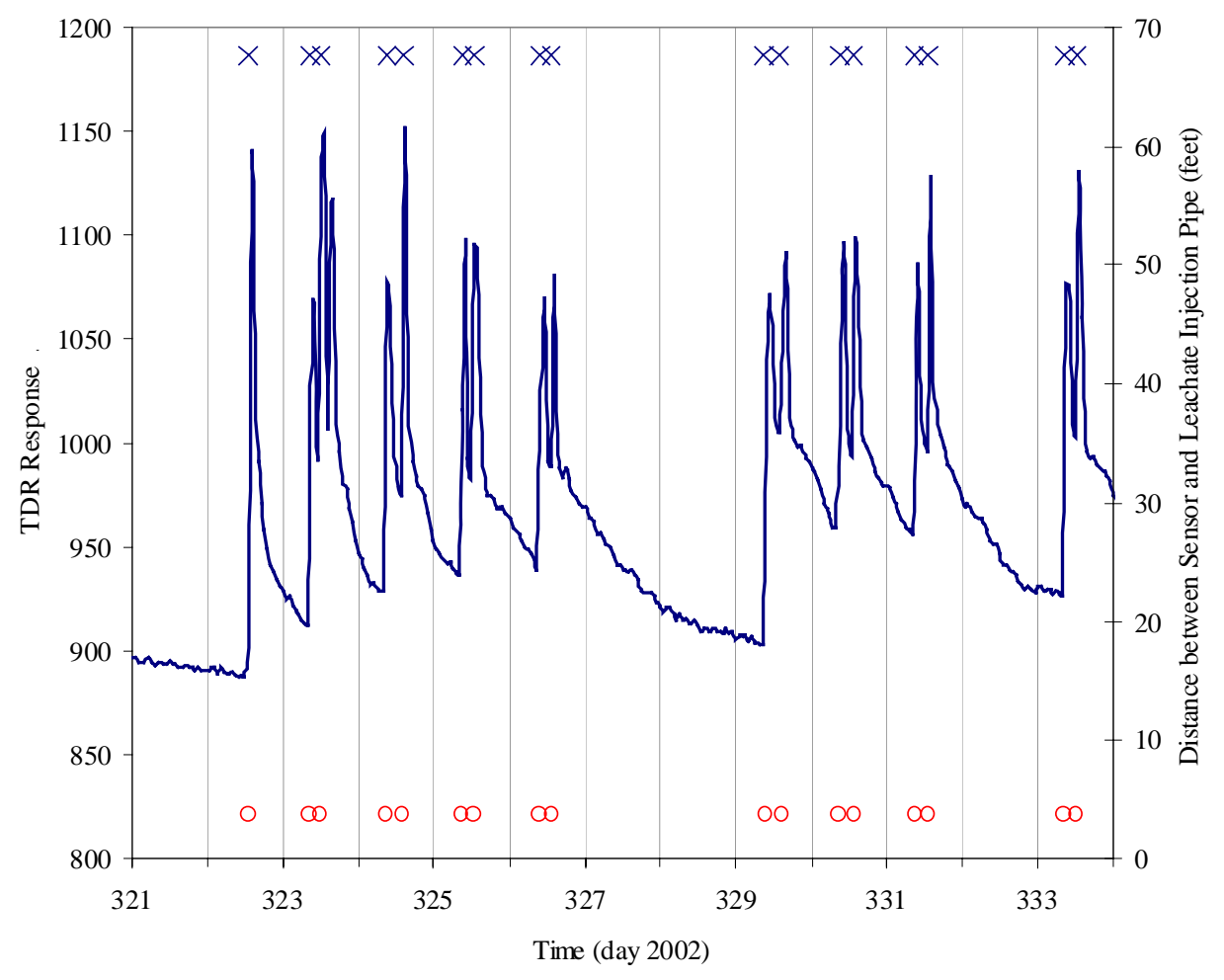

— Moisture $\quad$ Injection Pipe L24 $\times$ Injection Pipe L23

Figure 7-10: The moisture probe response to the leachate injection

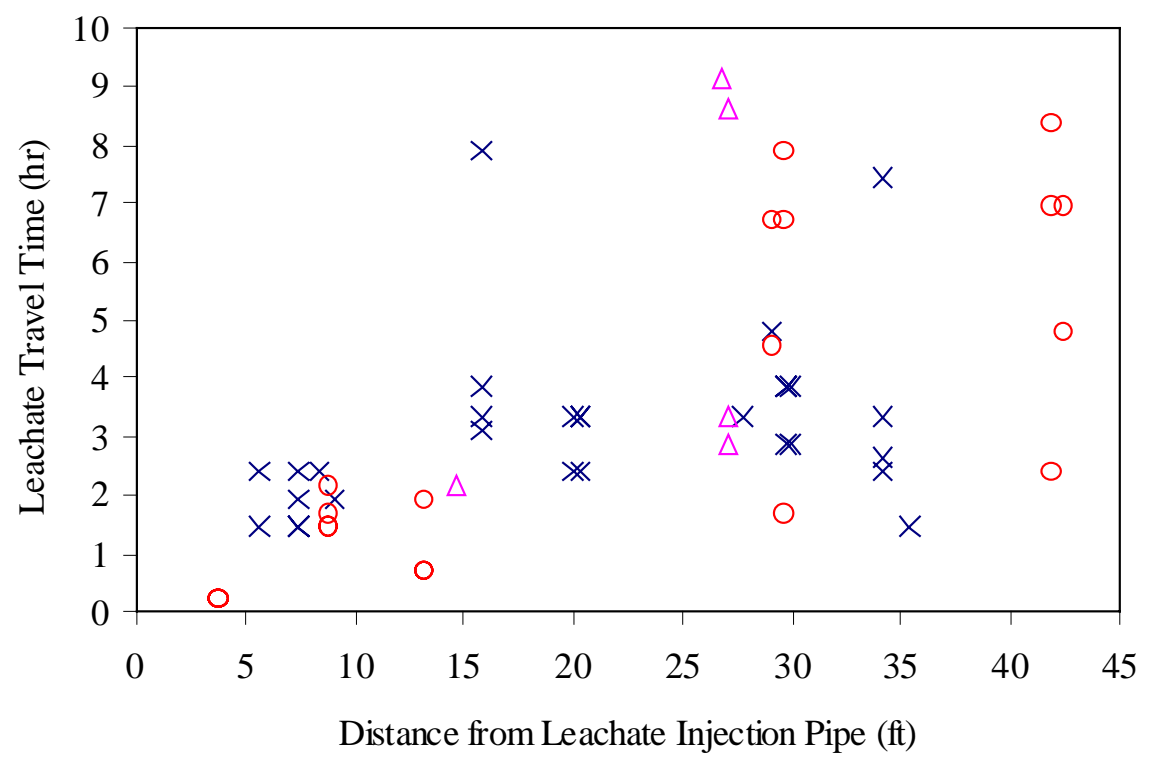

$\times$ Mount $\triangle 60$ wide Geocomposite $\circ 15$ wide Geocomposite

Figure 7-11: The leachate transport time vs. the distance from the injection pipe 


\subsection{Leachate Sample Collected from In-situ Leachate Basins}

As mentioned before, a total of 48 leachate collection basins were installed in the bioreactor landfill. To test the system, leachate was sampled from all basins in the Lift 1 on March 28, 2003 and April 4, 2003. Because the basins had not been emptied since the installation, the leachate pumped out on March 28, 2003 was due to the accumulation since the basin was installed. During this first attempt, water was pumped out from 16 of the total of 19 basins (Figure 7-12). Within the 16 basins, volume of water from five basins was equal to or greater than the capacity of the basin. One week after the first sampling event, the leachate was pumped out again from the basins. The water volume represented the collection of the leachate from the MSW during the one-week period. Leachate was found in 10 basins (Figure 7-12). Leachate was not injected into this lift since Dec. 18, 2002. The leachate injections were stopped in Lift 2 and 3 since Jan. 13 and Feb. 27 2003, respectively. The successful collection of the leachate in the basins indicated that there was still significant water movement in the landfill.

Electrical conductance (EC) and $\mathrm{pH}$ were determined for the leachate samples. The EC values were between 25 and $30 \mathrm{mS}$, and $\mathrm{pH}$ values were between 5.7 and 6.4 (Figure 7-13). Both EC and pH values were relatively constant for all locations. The results from this sampling event indicated that the leachate collection basin could be used to collect the leachate sample from the landfill. After the cell was closed, the leachate was routinely collected from all the basins using the same procedure. A comprehensive chemical analysis plan was developed to analyze the leachate samples.

To evaluate the heterogeneity in the leachate characteristics, a two-dimensional profile for most of the measured parameters was developed for each lift. The examples of $\mathrm{pH}$, EC, COD and temperature in Lift 1 are plotted in Figure 7-14. While pH and EC values in most parts of the lift were similar, east side of the lift had higher $\mathrm{pH}$ and low EC values. Very low levels of COD and higher temperatures were also found at these locations.

The pH, EC and COD values are plotted in Figure 7-15 for a sampling event on September 2, 2003 (operation day: 417). The average values and two times the standard deviation for each lift are also plotted. The $\mathrm{pH}$ at all locations was higher than 5.9 (Figure 7-15). The average EC was between 24 to 30 $\mathrm{mS} / \mathrm{cm}$. The COD was between 20,000 and 40,000 mg/L, except for one location in Lift 1 that had a value of 2,000 mg/L. There was no significant difference between lifts for all the three parameters. All parameters for leachate collected from the basins in Lift 4 were very close to each other and leachate samples were successfully collected from all six basins in the lift. This is because leachate was injected in the lift 4, 5 and 6 for three weeks just before the sampling. The chemical composition of the leachate collected in the basins was similar to that for the injected leachate. 


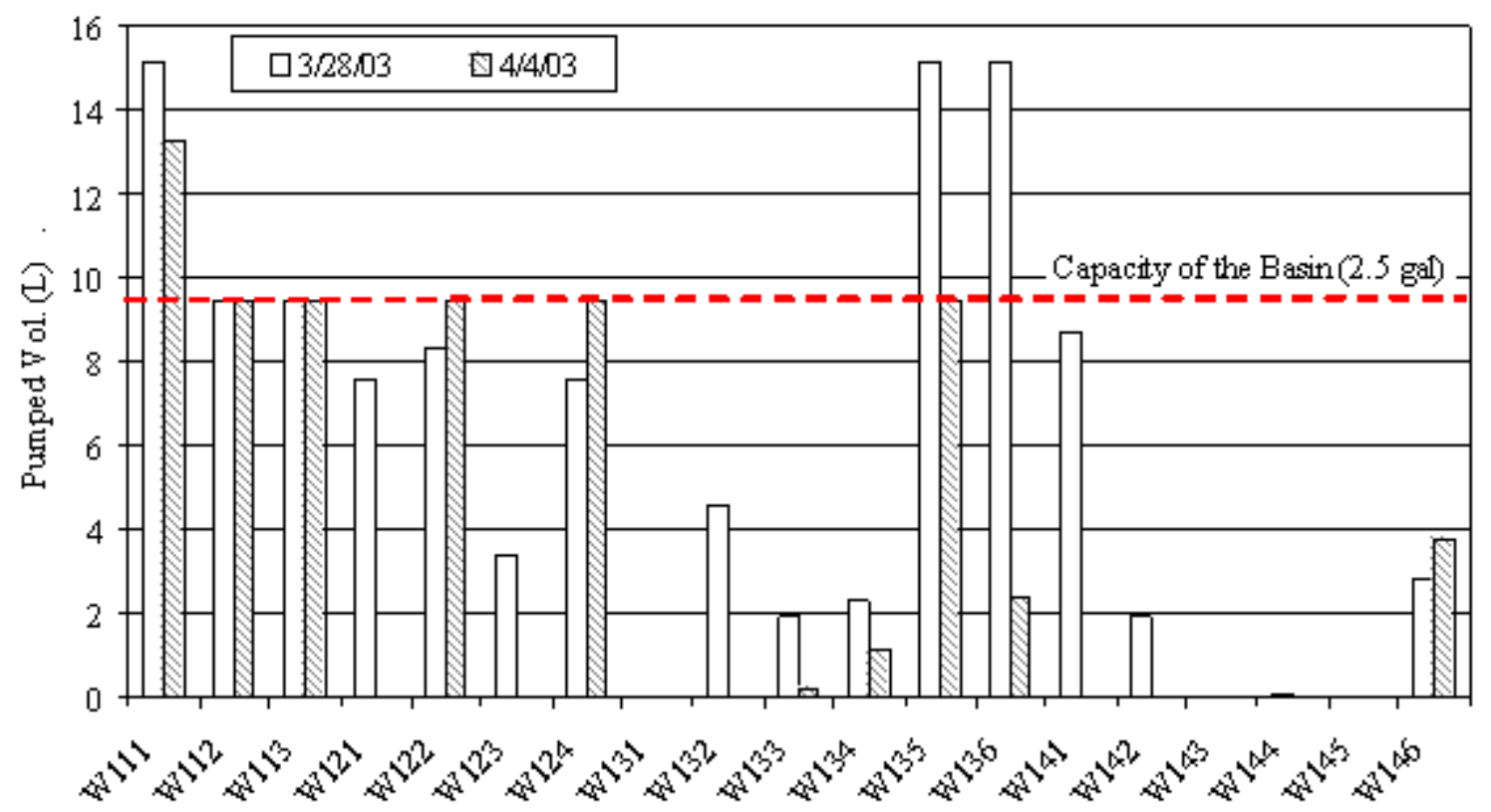

Figure 7-12: Volume of leachate pumped out of leachate collection basins in Lift 1

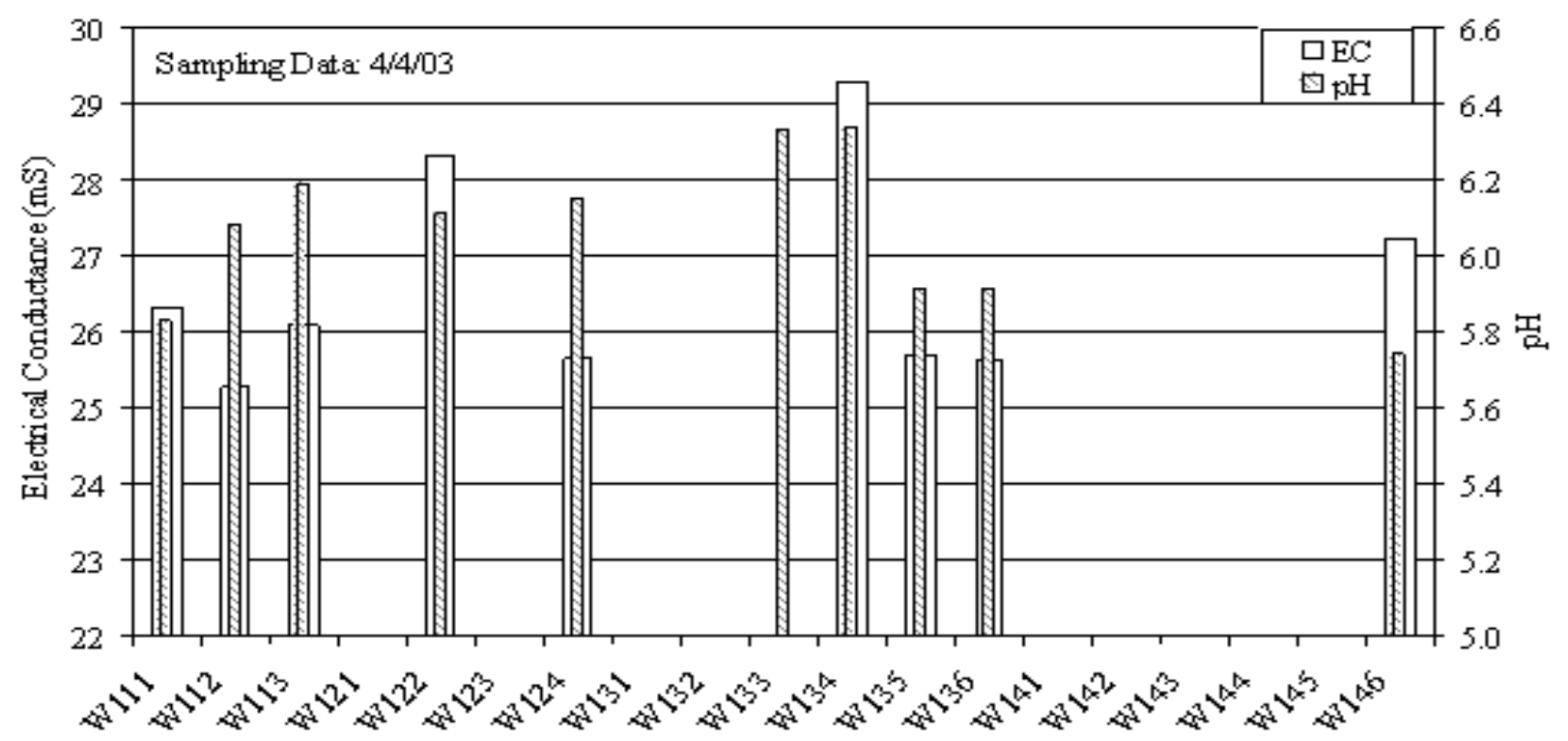

Figure 7-13: Electrical conductance and $\mathrm{pH}$ of the leachate collected from Lift 1 


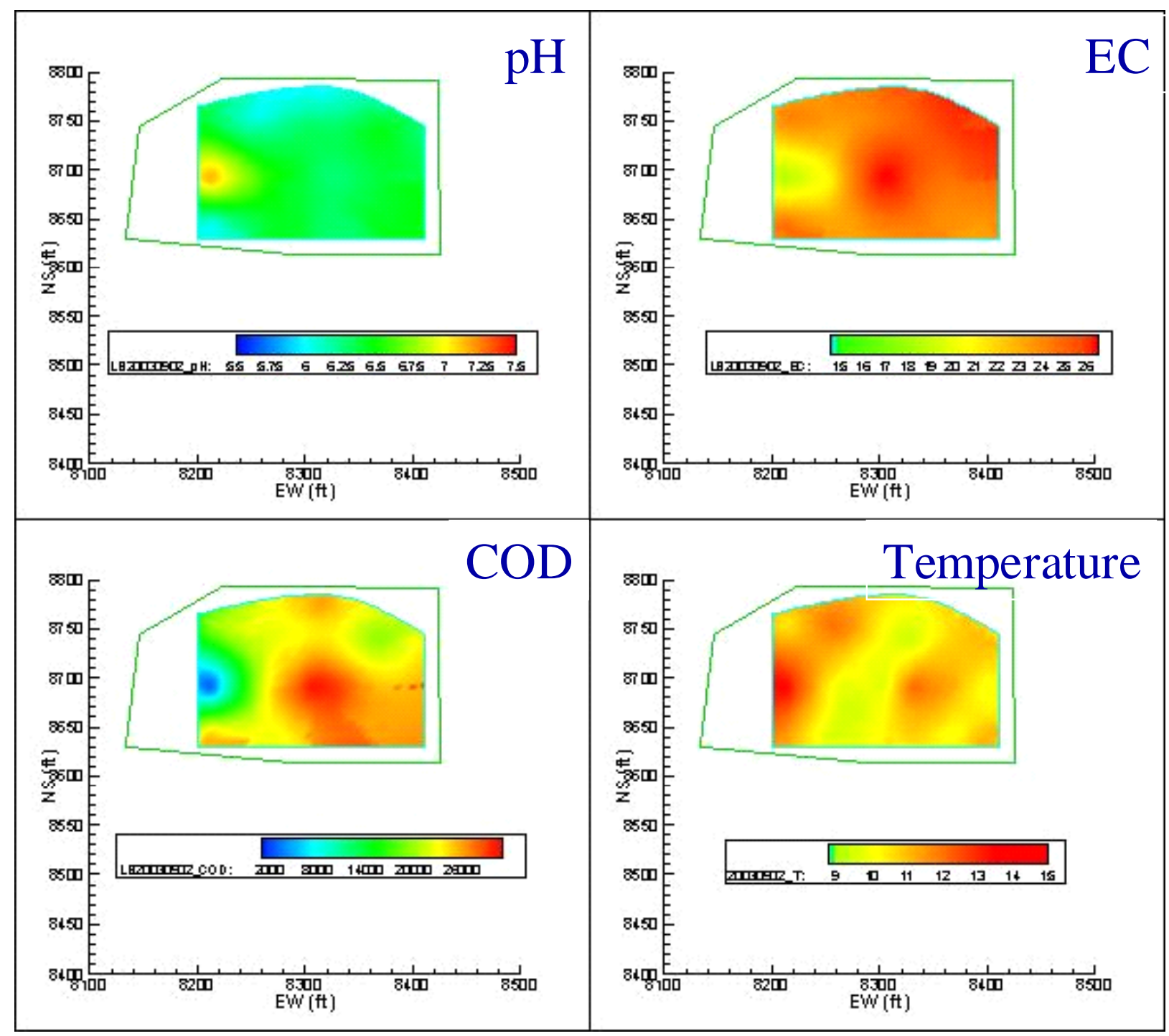

Figure 7-14: The distribution of $\mathrm{pH}, \mathrm{EC}, \mathrm{COD}$ and temperature in the leachate collected from Lift 1 (Sampling date: 9/2/03 Operational days: 417) 

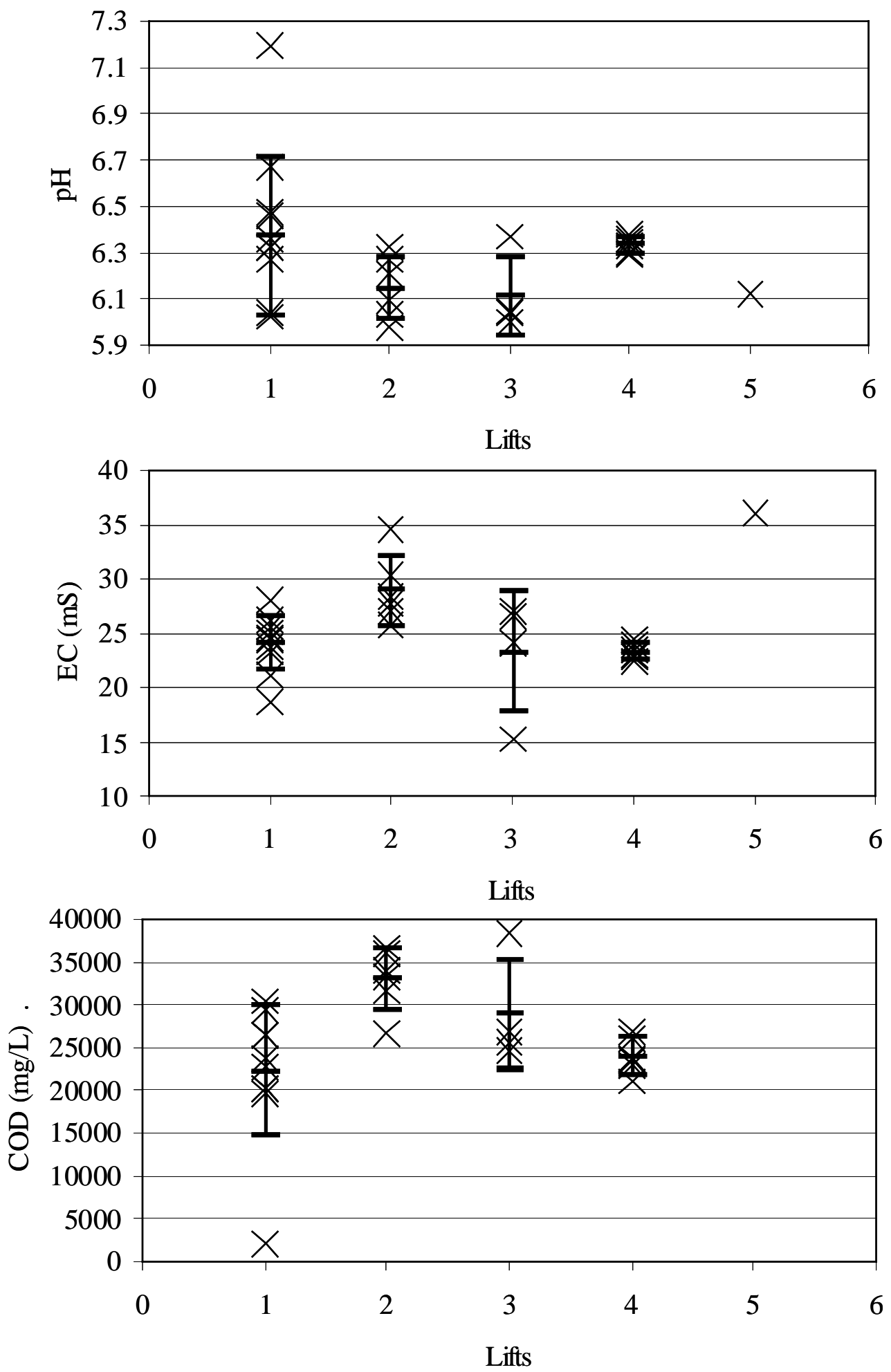

Figure 7-15: The pH, EC, and COD in the leachate collected from leachate collection basins. The vertical bars represent two times the standard deviation. The middle point on the bar is the average value. (Sampling date: 9/2/03 Operational days: 417). 


\subsection{Gas Composition in the Bioreactor Landfill}

A gas sampling port was also installed at each location where the moisture/temperature probe and leachate collection basins were installed. The gas samples were collected monthly from each port. The concentration of oxygen, nitrogen, carbon monoxide, carbon dioxide, methane, and hydrogen were determined using gas chromatography and reduction gas analyzer. The methane concentration profiles in Lift 1 are presented in Figure 7-16 along with the temperature profile. The methane concentration profile in Lift 3 is presented in Figure 7-17 along with the temperature profile. Significant levels of methane (20 - 30\% in the gas phase) were found in Lift 1 after 68 days of the completion of the lift. Methane concentration in the gas phase increased continuously thereafter and reached levels as high as $70 \%$ after 260 days of filling Lift 1 . By contrast, less than $2 \%$ methane was found in Lift 3 after 86 days, which increased to approximately $10 \%$ after 260 days. These results indicated that while gas production continued in Lift 1 at a significant rate, it was limited in Lift 3. Because of the early leachate injection, the moisture content in all four lower lifts was similar (Figure 7-9). After analyzing the temperature data, we concluded that the difference in gas production in both lifts might have resulted from the historical temperature difference in the waste. This issue is discussed further in the next section.

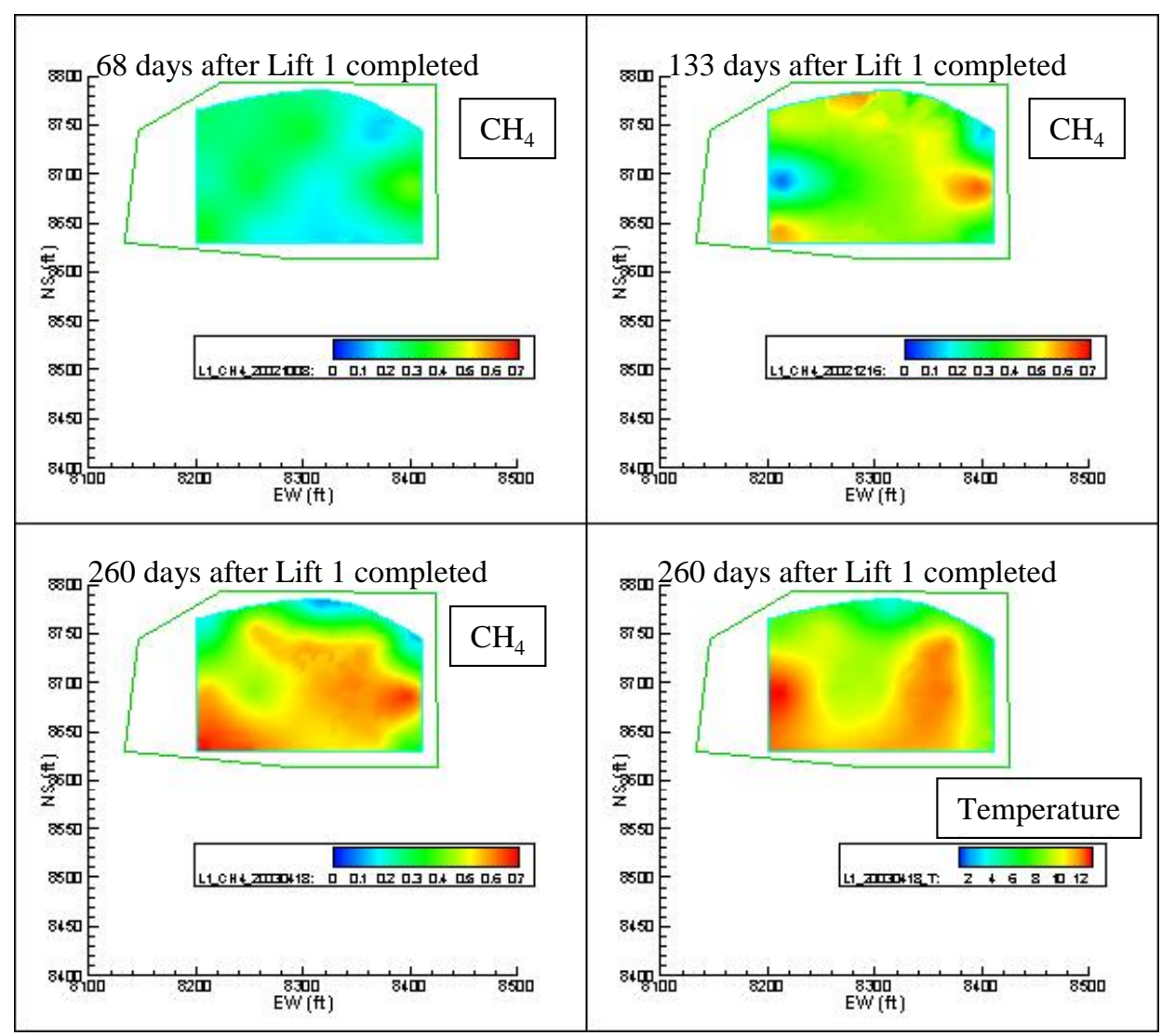

Figure 7-16: The distribution of methane concentration in Lift 1 at 68, 133 and 260 days after the lift was filled. The temperature in the lift 260 days after Lift 1 complete was also plotted. 


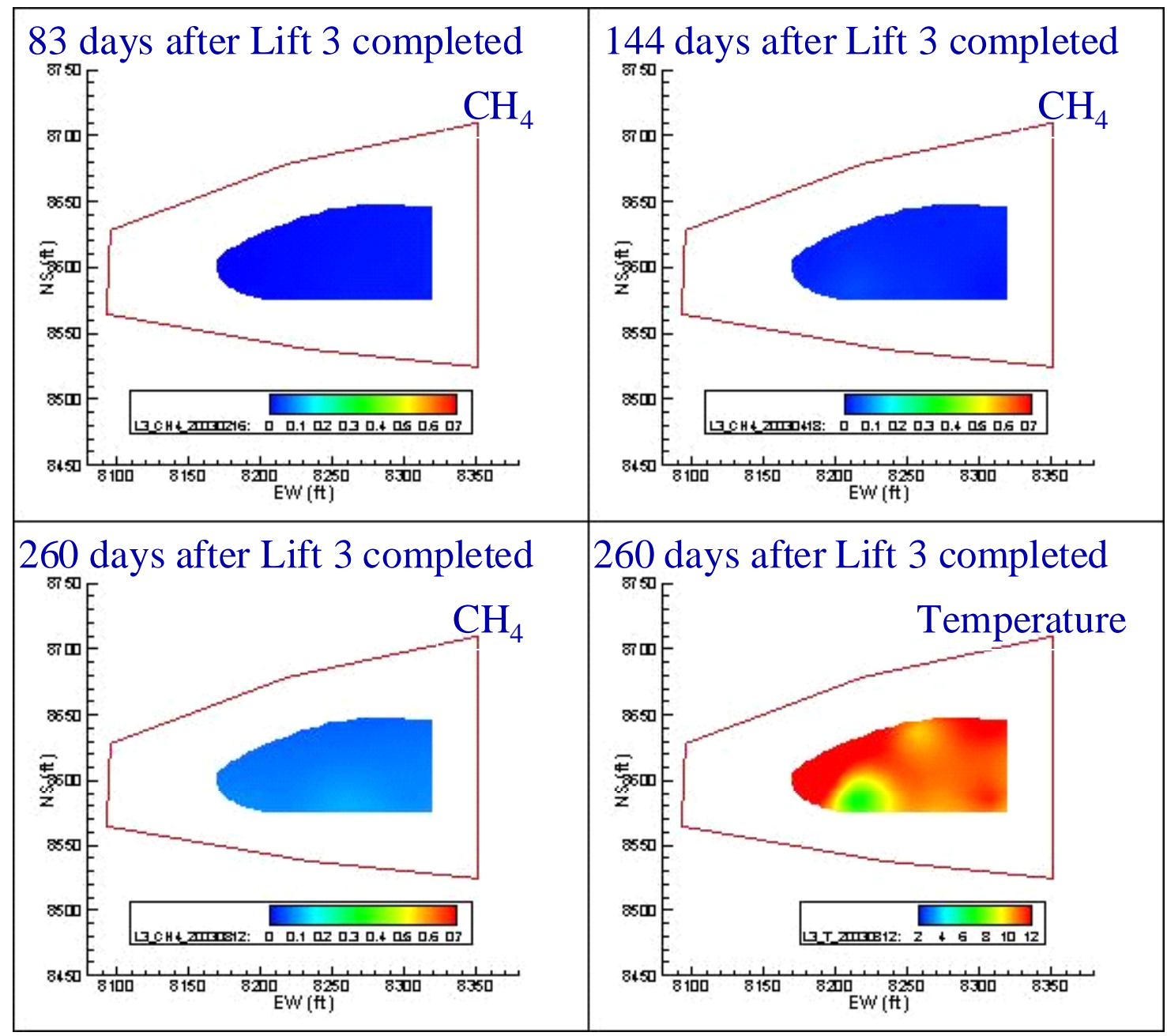

Figure 7-17: The distribution of methane concentration in Lift 3 at 83, 144 and 260 days after the lift was filled. The temperature in the lift 260 days after Lift 3 complete was also plotted.

The oxygen and carbon dioxide concentrations for Lifts 3, 4, and 5 (post-filled) are presented in Figure 7-18. In Lifts 3 and 5, oxygen was consumed and carbon dioxide was produced at all points. Oxygen was depleted within two to three weeks in Lift 3 and 5 after the lift was filled. In Lift 4, a low level of oxygen was detected for up to 50 days after the lift was filled. One of the reasons for the slow drop in oxygen level was that filling of Lift 5 did not start for 3 weeks after the filling of Lift 4 . Therefore, the gas ports were covered with only 5-feet of waste. Oxygen may have diffused into the waste during this period. 

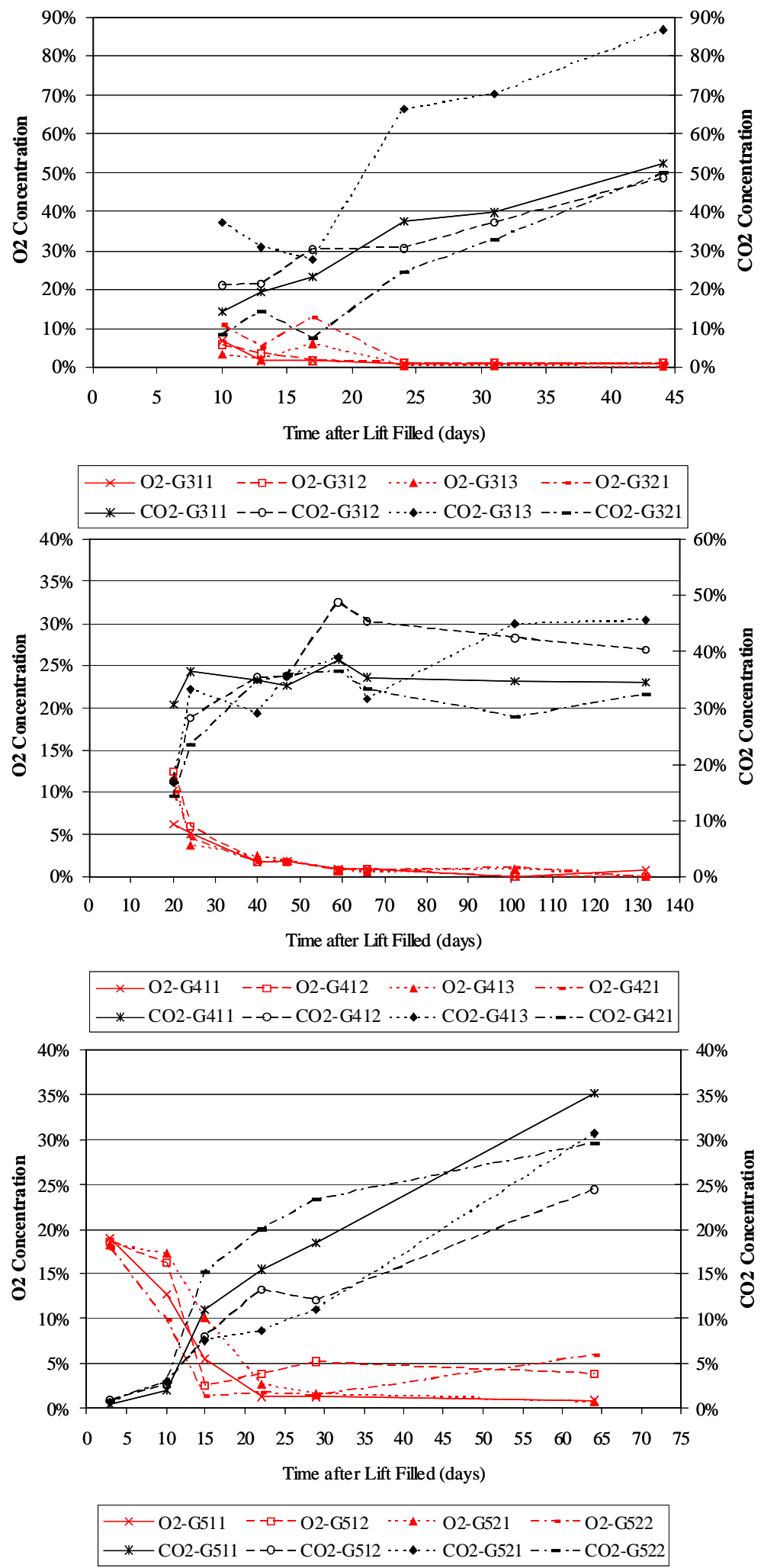

Figure 7-18: The oxygen $\left(\mathrm{O}_{2}\right)$ and carbon dioxide $\left(\mathrm{CO}_{2}\right)$ concentration in Lift 3, 4, and 5 after the lift filled 


\subsection{Leachate Characteristics in Sump Bioreactor Landfill}

After the bioreactor landfill was filled and covered, leachate samples were collected from the sump on a monthly basis. A comprehensive chemical analysis was conducted by an independent analytical laboratory (Severn Trent Laboratories, Buffalo, NY). Waste Management Inc. provided the funds for this analysis.

Table 7-1 lists some of the characteristics of leachate as given by this analysis. Values for $\mathrm{pH}$ and EC were quite stable (Figure 7-19). The $\mathrm{pH}$ was above 6.5 and sufficient alkalinity $\left(\sim 4,000 \mathrm{mg} / \mathrm{L}\right.$ as $\left.\mathrm{CaCO}_{3}\right)$ was present in the leachate. These values have relevance in the stability of anaerobic digestion process. The high alkalinity will also help to maintain the $\mathrm{pH}$ level. COD in the leachate was between $6000 \mathrm{mg} / \mathrm{L}$ and $9100 \mathrm{mg} / \mathrm{L}$. The ratios of TOC to COD were around 0.3 (Figure 7-20). There were inconsistencies in the BOD measurement (Figure 7-20) and ratios of BOD to COD fluctuated in the range of 0.4 to 0.9. However, even at the low ratios, a large amount of dissolve organic carbon should be bioavailable due to the high COD values.

Within the 46 measured volatile organic chemicals (see Table 7-2 for complete list), four VOCs were consistently present above the detection limit in all samples: acetone, methyl ethyl ketone, methyl isobutyl ketone, and toluene. Methylene chlorine and total xylenes were also detected in two samples. Within all detectable VOCs, acetone and methyl ethyl ketone were present at much higher concentrations (7-17 mg/L and 16-38 mg/L, respectively). Dissolved methane was also monitored in the leachate. It was present in the range of 1.6 to $3.8 \mathrm{mg} / \mathrm{L}$.

The leachate was also analyzed for a total of 22 metals listed in Table 7-3. Low levels of heavy metals such as arsenic, chromium and zinc, were found. Lead and thallium were below the detection limits of 0.05 and $0.002 \mathrm{mg} / \mathrm{L}$, respectively. Copper, iron, boron, cobalt, calcium, and potassium were

present at trace levels in the leachate. This indicated that the leachate in this landfill had the essential trace metals necessary for anaerobic biodegradation processes. 

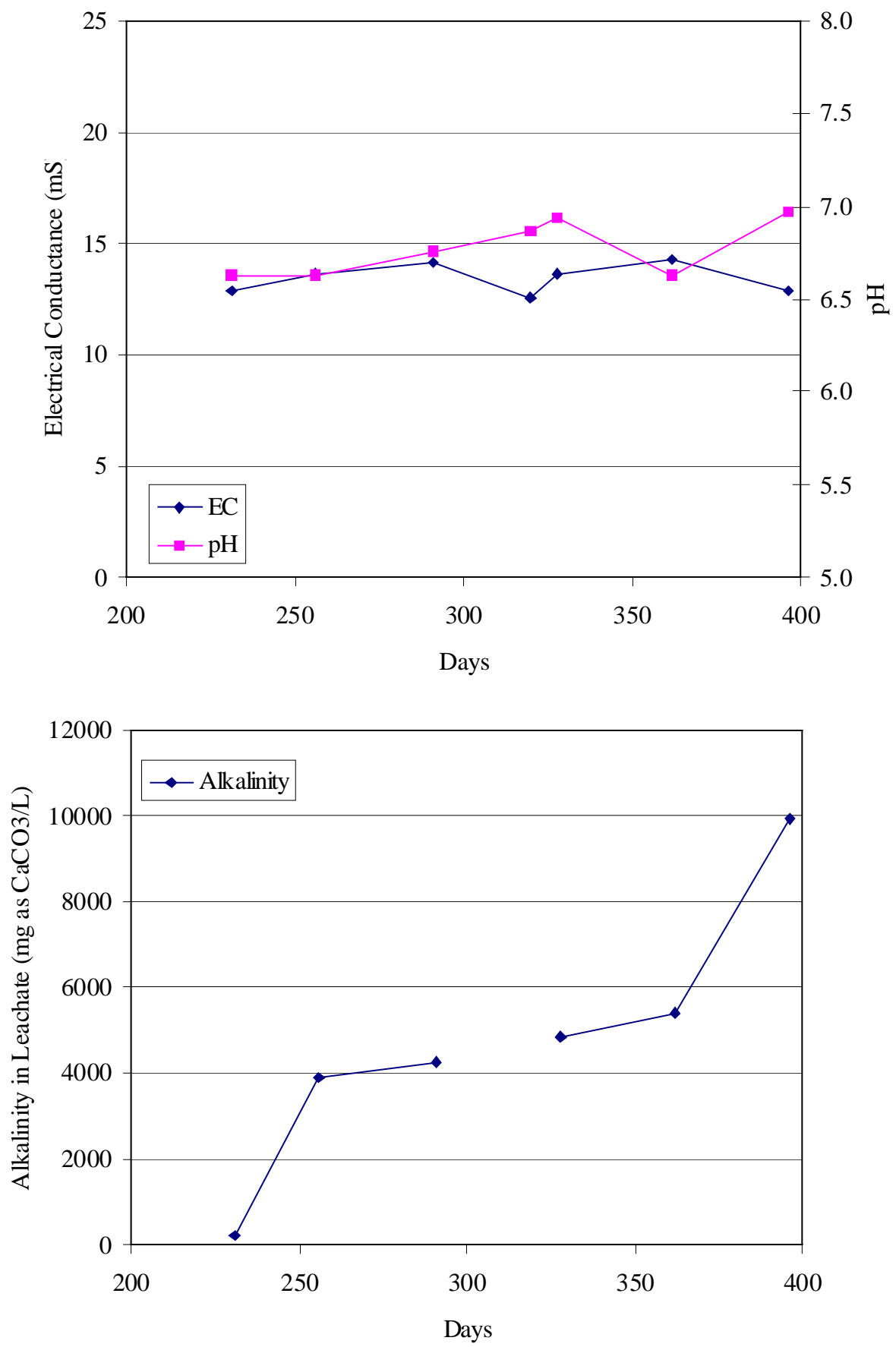

Figure 7-19: The pH, EC and alkalinity in the leachate samples from bioreactor sump 

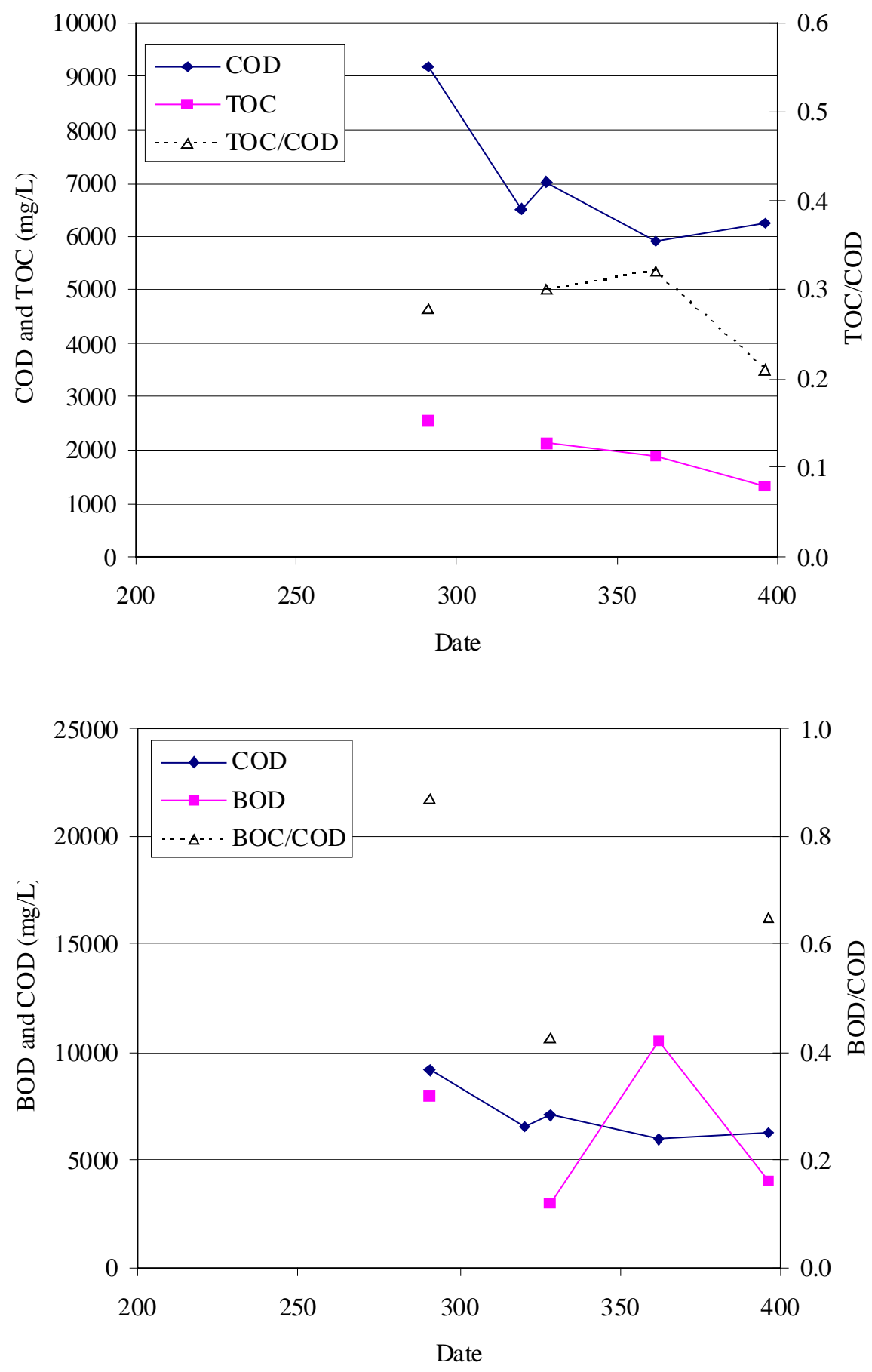

Figure 7-20: The COD, BOD and TOC in the leachate samples from bioreactor sump 
Table 7-1: Chemical characteristics of samples collected from bioreactor landfill sump

\begin{tabular}{|c|c|c|c|c|c|c|c|c|}
\hline \multirow{3}{*}{\begin{tabular}{|l|} 
Sampling Date \\
Operation Day \\
\end{tabular}} & \multicolumn{2}{|c|}{$2 / 28 / 2003$} & \multicolumn{2}{|c|}{$3 / 25 / 2003$} & \multicolumn{2}{|c|}{$4 / 29 / 2003$} & \multicolumn{2}{|c|}{$6 / 5 / 2003$} \\
\hline & \multicolumn{2}{|c|}{231} & \multicolumn{2}{|c|}{256} & \multicolumn{2}{|c|}{291} & \multicolumn{2}{|c|}{328} \\
\hline & Conc. & Det. Limit & Conc. & Det. Limit & Conc. & Det. Limit & Conc. & Det. Limit \\
\hline & $\mathrm{mg} / \mathrm{L}$ & $\mathbf{m g} / \mathbf{L}$ & $\mathrm{mg} / \mathrm{L}$ & $\mathrm{mg} / \mathrm{L}$ & $\mathbf{m g} / \mathbf{L}$ & $\mathbf{m g} / \mathbf{L}$ & $\mathbf{m g} / \mathbf{L}$ & $\mathbf{m g} / \mathbf{L}$ \\
\hline Alkalinity, Bicarbonate (as CaCO3 & 229 & 10 & 3900 & 100 & 4260 & 100 & 4840 & 10 \\
\hline Alkalinity, Carbonate (as CaCO3) & ND & 10 & ND & 10 & ND & 10 & ND & 10 \\
\hline Alkalinity, Total (as CaCO3) & 229 & 10 & 3900 & 100 & 4260 & 100 & 4840 & 10 \\
\hline Ammonis (as N) & 801 & 5 & 393 & 10 & 536 & 5 & 496 & 5 \\
\hline BOD & 16000 & 100 & 7230 & 1000 & 7980 & 100 & 3000 & 1 \\
\hline COD & 7940 & 100 & 12240 & 500 & 9182 & 50 & 7034 & \\
\hline Chloride & 3520 & 100 & 2440 & 100 & 2240 & 50 & 2340 & 100 \\
\hline Electrical Conductance & 12870 & & 13640 & & 14140 & & 13660 & \\
\hline Nitrate (as N) & 0.05 & 0.05 & 0.27 & 0.05 & ND & 0.05 & $\mathrm{ND}$ & 0.05 \\
\hline $\mathrm{pH}$ & 6.63 & 0 & 6.63 & 0 & 6.76 & 0 & 6.94 & \\
\hline Phosphate, Ortho & 2.8 & 0.1 & 1.6 & 0.1 & 0.74 & 0.04 & 0.64 & 0.2 \\
\hline Phosphorous, Total & 2.9 & 0.05 & 4.4 & 0.1 & 3.5 & 0.05 & 3.6 & 0.1 \\
\hline Sulfate & 422 & 40 & 525 & 100 & 126 & 10 & 124 & 10 \\
\hline Temperature & 8.9 & 0 & 8.7 & 0 & 11.4 & 0 & 13.0 & \\
\hline Total Kjeldahl Nitrogen (TKN) & 835 & 100 & 427 & 50 & 475 & 50 & 464 & 100 \\
\hline TOC & 12284 & 125 & 3935 & 50 & 2560 & 50 & 2120 & 25 \\
\hline
\end{tabular}


Table 7-2: Volatile organic chemicals (VOC) in leachate samples collected from bioreactor landfill sump

\begin{tabular}{|c|c|c|c|c|c|c|c|c|}
\hline \multirow{3}{*}{\begin{tabular}{|l|} 
Sampling Date \\
Operation Day \\
\end{tabular}} & \multicolumn{2}{|c|}{$2 / 28 / 2003$} & \multicolumn{2}{|c|}{$3 / 25 / 2003$} & \multicolumn{2}{|c|}{$4 / 29 / 2003$} & \multicolumn{2}{|c|}{$6 / 5 / 2003$} \\
\hline & \multicolumn{2}{|c|}{231} & \multicolumn{2}{|c|}{256} & \multicolumn{2}{|c|}{291} & \multicolumn{2}{|c|}{328} \\
\hline & Conc. & Det. Limit & Conc. & Det. Limit & Conc. & Det. Limit & Conc. & Det. Limit \\
\hline & ug/L & ug/L & ug/L & \begin{tabular}{|l|l}
$\mathbf{u g} / \mathbf{L}$ \\
\end{tabular} & ug/L & ug/L & ug/L & ug/L \\
\hline 1,1,1,2-Tetrachloroethane & $\mathrm{ND}$ & 5.6 & $\mathrm{ND}$ & 45 & $\mathrm{ND}$ & 45 & $\mathrm{ND}$ & 1.1 \\
\hline 1,1,1-Trichloroethane & ND & 8.5 & ND & 68 & ND & 68 & $\mathrm{ND}$ & 1.7 \\
\hline 1,1,2,2-Tetrachloroethane & ND & 10 & ND & 83 & ND & 83 & ND & 2.1 \\
\hline 1,1,2-Trichloroethane & ND & 7.2 & ND & 57 & ND & 57 & $\mathrm{ND}$ & 1.4 \\
\hline 1,1-Dichloroethane & ND & 13 & ND & 100 & ND & 100 & ND & 2.6 \\
\hline 1,1-Dichloroethene & ND & 10 & ND & 82 & ND & 82 & ND & 2.1 \\
\hline \begin{tabular}{|l|l}
$1,2,3$-Trichloropropane \\
\end{tabular} & ND & 15 & ND & 120 & ND & 120 & ND & 3.1 \\
\hline 1,2-Dibromo-3-Chloropropane DBCH & ND & 19 & ND & 150 & ND & 150 & ND & 5 \\
\hline 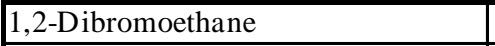 & ND & 7.7 & ND & 61 & ND & 61 & $\mathrm{ND}$ & 1.5 \\
\hline 1,2-Dichlorobenzene & ND & 7.8 & ND & 63 & ND & 63 & ND & 1.6 \\
\hline 1,2-Dichloroethane & ND & 8.1 & ND & 65 & ND & 65 & ND & 1.6 \\
\hline 1,2-Dichloropropane & ND & 9.6 & ND & 77 & ND & 77 & ND & 1.9 \\
\hline 1,4-Dichlorobenzene & ND & 8.2 & ND & 65 & ND & 65 & $\mathrm{ND}$ & 1.6 \\
\hline 2-Hexanone & ND & 31 & ND & 250 & $\mathrm{ND}$ & 250 & 55 & 6.3 \\
\hline Acetone & 17000 & 670 & 12000 & 670 & 14000 & 670 & 7300 & 670 \\
\hline Acrylonitrile & ND & 21 & ND & 170 & ND & 170 & $\mathrm{ND}$ & 5 \\
\hline Benzene & ND & 10 & ND & 80 & ND & 80 & 6 & 2 \\
\hline Bromochloromethane & ND & 10 & ND & 84 & ND & 84 & ND & 2.1 \\
\hline Bromoform & ND & 6.8 & ND & 54 & ND & 54 & ND & 1.4 \\
\hline Bromomethane & ND & 13 & ND & 100 & ND & 100 & $\mathrm{ND}$ & 5 \\
\hline Carbon Disulfide & ND & 14 & ND & 110 & ND & 110 & $\mathrm{ND}$ & 5 \\
\hline Carbon Tetrachloride & ND & 12 & ND & 97 & ND & 97 & $\mathrm{ND}$ & 2.4 \\
\hline Chlorobenzene & ND & 9.7 & ND & 78 & ND & 78 & $\mathrm{ND}$ & 1.9 \\
\hline Chloro ethane & ND & 11 & ND & 89 & ND & 89 & ND & 5 \\
\hline Chloro form & ND & 9.6 & ND & 76 & ND & 76 & ND & 1.9 \\
\hline Chloromethane & ND & 12 & ND & 97 & ND & 97 & $\mathrm{ND}$ & 5 \\
\hline cis-1,2-Dichloro ethene & ND & 6.9 & ND & 55 & ND & 55 & 2.2 & 1.4 \\
\hline cis-1,3-Dichloropropene & ND & 7.6 & ND & 61 & ND & 61 & $\mathrm{ND}$ & 1.5 \\
\hline Dibromochloromethane & ND & 7.1 & ND & 57 & ND & 57 & $\mathrm{ND}$ & 1.4 \\
\hline Dibromomethane & ND & 8.5 & ND & 68 & ND & 68 & $\mathrm{ND}$ & 1.7 \\
\hline Dichlorobromomethane & ND & 6.1 & ND & 49 & ND & 49 & $\mathrm{ND}$ & 1.2 \\
\hline Ethylbenzene & ND & 9.4 & ND & 75 & $\mathrm{ND}$ & 75 & 12 & 1.9 \\
\hline Iodomethane & $\mathrm{ND}$ & 14 & $\mathrm{ND}$ & 120 & $\mathrm{ND}$ & 120 & 3.4 & 2.9 \\
\hline Methyl Ethyl Ketone & 38000 & 550 & 23000 & 550 & 30000 & 550 & 16000 & 550 \\
\hline Methyl Isobutyl Ketone & 540 & 28 & 540 & 220 & 300 & 220 & 320 & 5.6 \\
\hline Methylene chloride & 130 & 19 & ND & 150 & ND & 150 & 21 & 5 \\
\hline Styrene & ND & 8.9 & ND & 71 & ND & 71 & 2.4 & 1.8 \\
\hline Tetrachloroethene & ND & 9.8 & ND & 78 & ND & 78 & ND & 2 \\
\hline Toluene & 310 & 8.5 & 330 & 68 & 430 & 68 & 360 & 68 \\
\hline Total Xylenes & 40 & 13 & $\mathrm{ND}$ & 100 & ND & 100 & 31 & 3 \\
\hline trans-1,2-Dichloroethene & ND & 15 & ND & 120 & ND & 120 & $\mathrm{ND}$ & 2.9 \\
\hline trans-1,3-Dichloropropene & ND & 6.5 & ND & 52 & ND & 52 & $\mathrm{ND}$ & 1.3 \\
\hline trans-1,4-dichloro-2-buten & ND & 24 & ND & 190 & ND & 190 & $\mathrm{ND}$ & 4.8 \\
\hline Trichloroethene & ND & 7.8 & ND & 62 & ND & 62 & 3 & 1.6 \\
\hline Trichlorofluoromethane & ND & 13 & ND & 100 & ND & 100 & $\mathrm{ND}$ & 5 \\
\hline Vinyl chloride & $\mathrm{ND}$ & 10 & $\mathrm{ND}$ & 81 & ND & 81 & $\mathrm{ND}$ & 2 \\
\hline & $\mathrm{mg} / \mathrm{L}$ & $\mathrm{mg} / \mathrm{L}$ & $\mathrm{mg} / \mathrm{L}$ & $\mathrm{mg} / \mathrm{L}$ & $\mathrm{mg} / \mathrm{L}$ & $\mathrm{mg} / \mathrm{L}$ & $\mathrm{mg} / \mathrm{L}$ & $\mathrm{mg} / \mathrm{L}$ \\
\hline Methane & 3.8 & 2 & 2.7 & 0.044 & 2.7 & 0.044 & 1.6 & 0.03 \\
\hline
\end{tabular}


Table 7-3: Total metal in leachate samples collected from bioreactor landfill sump

\begin{tabular}{|c|c|c|c|c|c|c|c|c|}
\hline \multirow{3}{*}{\begin{tabular}{|l|} 
Sampling Date \\
Operation Day \\
\end{tabular}} & \multicolumn{2}{|c|}{$2 / 28 / 2003$} & \multicolumn{2}{|c|}{$3 / 25 / 2003$} & \multicolumn{2}{|c|}{$4 / 29 / 2003$} & \multicolumn{2}{|c|}{$6 / 5 / 2003$} \\
\hline & \multicolumn{2}{|c|}{231} & \multicolumn{2}{|c|}{256} & \multicolumn{2}{|c|}{291} & \multicolumn{2}{|c|}{328} \\
\hline & Conc. & Det. Limit & Conc. & Det. Limit & Conc. & Det. Limit & Conc. & Det. Limit \\
\hline & $\mathrm{mg} / \mathrm{L}$ & $\mathrm{mg} / \mathrm{L}$ & $\mathrm{mg} / \mathrm{L}$ & $\mathrm{mg} / \mathrm{L}$ & $\mathrm{mg} / \mathrm{L}$ & mg/L & $\mathrm{mg} / \mathrm{L}$ & $\mathrm{mg} / \mathrm{L}$ \\
\hline Antimony & 0.018 & 0.002 & 0.015 & 0.002 & 0.016 & 0.002 & 0.01 & 0.002 \\
\hline Arsenic & 0.11 & 0.001 & 0.073 & 0.001 & 0.066 & 0.0014 & 0.066 & 0.0014 \\
\hline Barium & 0.72 & 0.005 & 0.52 & 0.005 & 0.6 & 0.005 & 0.54 & 0.005 \\
\hline Beryllium & 0.0011 & 0.001 & nd & 0.001 & nd & 0.001 & ND & 0.001 \\
\hline Boron & 14.4 & 0.02 & 8.5 & 0.02 & 9.2 & 0.02 & 8.5 & 0.02 \\
\hline Cedmium & ND & 0.02 & nd & 0.02 & nd & 0.02 & ND & 0.02 \\
\hline Calcium & 1560 & 1.6 & 1030 & 1 & 811 & 1 & 700 & 1 \\
\hline Chromium & 0.14 & 0.02 & 0.077 & 0.02 & 0.064 & 0.02 & 0.051 & 0.02 \\
\hline Cobalt & 0.12 & 0.015 & 0.11 & 0.015 & 0.041 & 0.015 & 0.019 & 0.015 \\
\hline Copper & 0.033 & 0.02 & nd & 0.02 & nd & 0.02 & ND & 0.02 \\
\hline Iron & 224 & 0.033 & 157 & 0.033 & 120 & 0.033 & 92 & 0.033 \\
\hline Lead & ND & 0.05 & nd & 0.05 & nd & 0.05 & ND & 0.05 \\
\hline Magnesium & 433 & 1 & 276 & 1 & 292 & 1 & 283 & 1 \\
\hline Mangnanese & 13.1 & 0.02 & 8.1 & 0.02 & 6.2 & 0.02 & 5 & 0.02 \\
\hline Nickel & 0.29 & 0.05 & 0.18 & 0.05 & 0.16 & 0.05 & 0.15 & 0.05 \\
\hline Potassium & 778 & 5.6 & 521 & 1.4 & 529 & 2.8 & 548 & 1.1 \\
\hline Selenium & 0.12 & 0.002 & 0.098 & 0.002 & 0.084 & 0.0022 & 0.1 & 0.0022 \\
\hline Silver & 0.00096 & 0.0005 & nd & 0.0005 & nd & 0.0005 & $\mathrm{ND}$ & 0.0005 \\
\hline Sodium & 2110 & 34.9 & 1460 & 8.7 & 1520 & 17.4 & 1590 & 7 \\
\hline Thallium & ND & 0.002 & nd & 0.002 & nd & 0.002 & ND & 0.002 \\
\hline Vanadium & 0.022 & 0.01 & 0.018 & 0.01 & 0.022 & 0.01 & 0.025 & 0.01 \\
\hline Zinc & 6.7 & 0.05 & 3 & 0.05 & 1.4 & 0.05 & 1 & 0.05 \\
\hline
\end{tabular}

\subsection{Differential Settlements in the Bioreactor Landfill}

Landfill settlement is another parameter indicative of long-term effect of degradation process. As the organic portion in the solid waste is degraded, the volume of the waste should decrease. The settlement of each lift in this bioreactor cell was monitored using the settlement profiler conduits installed on top of each lift. The elevations of the conduits were surveyed each month using the settlement profiler. The elevations of six conduits are presented in Figure 7-21. The data represented two sets of survey results. The first set was the results from the surveys just after the conduit installed. The second set was from the surveys after the filling of the cell was completed.

Average settlement of each conduit is presented in Table 7-4. Settlement was found to be a function of settlement time and waste thickness below and above the conduits. Data analysis for settlement was somewhat confounded by the fact that the cell was partially laid on the slope of existing adjacent cell (Figure 4-4 and 5-2). Lifts 4, 5, and 6 were laid entirely on the adjacent cell. The total settlement of the bioreactor could not be represented by the settlement of the top lift. To calculate the volume change of the waste, the top and bottom elevations of the bioreactor had to be interpolated. 


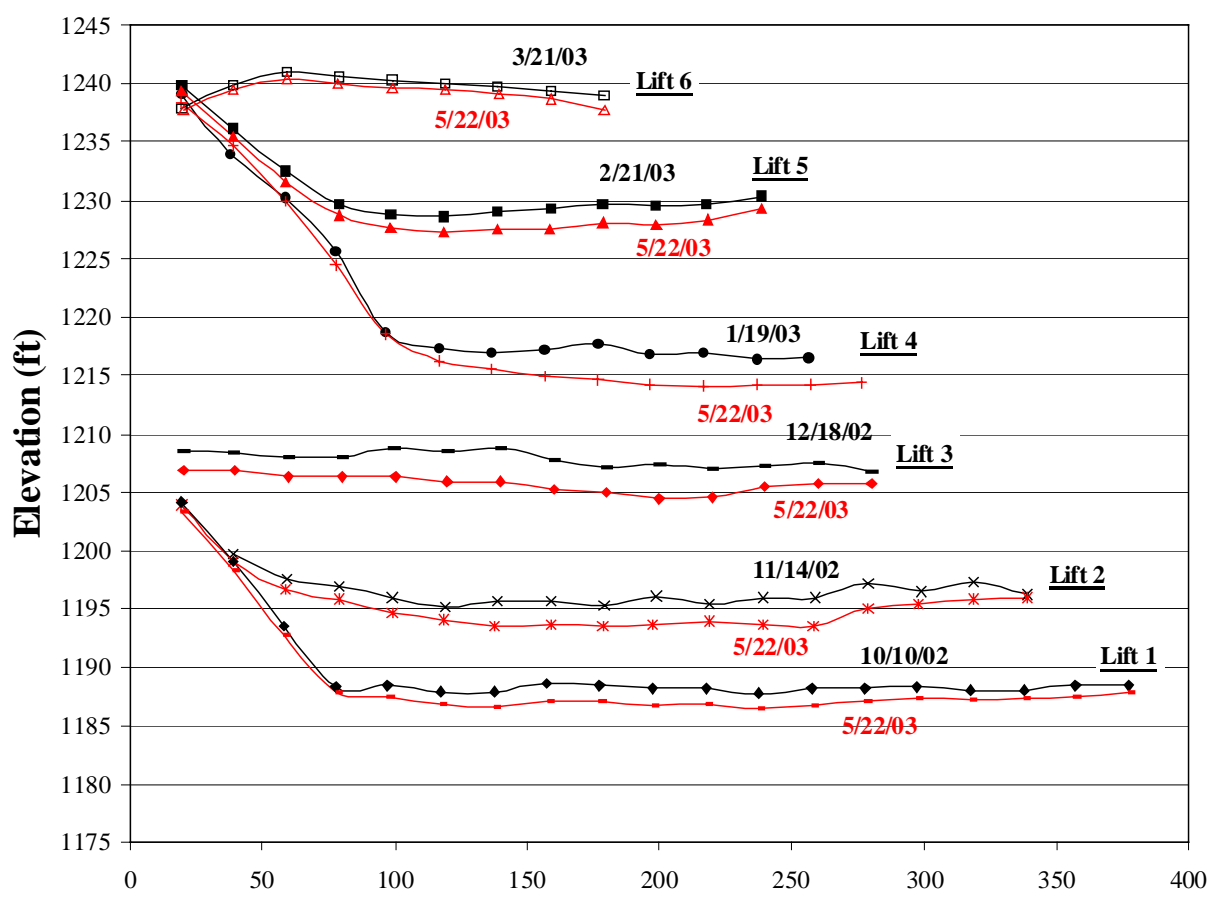

Distance from the entrance of the profiler conduit (ft)

Figure 7-21: The elevations of settlement profiler conduits at each lift.

Table 7-4: Accumulated settlement of profilers on top of each lift

\begin{tabular}{|c|c|c|c|c|c|}
\hline Lift & Profiler & $\begin{array}{c}\text { First } \\
\text { Survey }\end{array}$ & $\begin{array}{c}\text { Last } \\
\text { Survey }\end{array}$ & Days & $\begin{array}{c}\text { Average Settlement } \\
\text { in } \mathrm{ft}\end{array}$ \\
\hline 1 & $\mathrm{~S}-13$ & $10 / 10 / 2002$ & $5 / 22 / 2003$ & 224 & 0.51 \\
\hline 2 & $\mathrm{~S}-22$ & $11 / 14 / 2002$ & $5 / 22 / 2003$ & 189 & 1.55 \\
\hline 3 & $\mathrm{~S}-32$ & $12 / 18 / 2002$ & $5 / 22 / 2003$ & 155 & 2.30 \\
\hline 4 & $S-41$ & $1 / 19 / 2003$ & $5 / 22 / 2003$ & 123 & 2.20 \\
\hline 5 & $S-51$ & $2 / 21 / 2003$ & $5 / 22 / 2003$ & 90 & 1.38 \\
\hline 6 & $S-61$ & $2 / 21 / 2003$ & $5 / 22 / 2003$ & 62 & 0.68 \\
\hline
\end{tabular}

\subsection{Waste Temperature}

In addition to the moisture, temperature could play an important role for waste degradation. Mesophilic anaerobic microbial consortia require about 35 to $37{ }^{\circ} \mathrm{C}$ for optimal activity. When a bioreactor landfill is constructed in a warm climate, low temperatures in the waste will not be an issue. However, for a bioreactor landfill constructed in the northern part of the United States, the low temperature conditions in the landfill could be a problem, especially for waste placed in colder months.

The bottom lift of this bioreactor cell was filled during August 2002 resulting in an average temperature of approximately $29^{\circ} \mathrm{C}$ (Figure 7-22). This high temperature was caused by two factors. 
First, the air temperature during the summer was between 15 and $32{ }^{\circ} \mathrm{C}$ (Figure 7-22) such that high temperatures were likely prevalent in the waste at the time conditions. Second, due to fill delay, the bottom lift was not covered with waste for two months. The oxygen in the air could diffuse into the waste and result in aerobic activity and exothermic reaction - similar to composting. The heat generated by aerobic process may have been partially responsible for increasing the temperature of the waste.

However, the top four lifts (Lift 3, 4, 5 and 6) were filled during winter months (Figure 7-22). The air temperature at site was below $0{ }^{\circ} \mathrm{C}$ during most of this period. On some nights, the air temperature dropped to as low as $-30^{\circ} \mathrm{C}$. The temperature of waste was close to or below the freezing point. Due to the small size of the lifts, the filling process was relatively fast, i.e., without allowing much time in between filling two lifts. Even under such freezing conditions, oxygen depletion occurred in Lifts 3 and 5 within two weeks (Figure 7-18). As we mentioned earlier, the depletion of oxygen in Lift 4 was slower than in the other two lifts, perhaps due to the shorter delay in filling (Figure 7-18). This delay may have slightly increased the temperature in the waste (Figure 7-23).

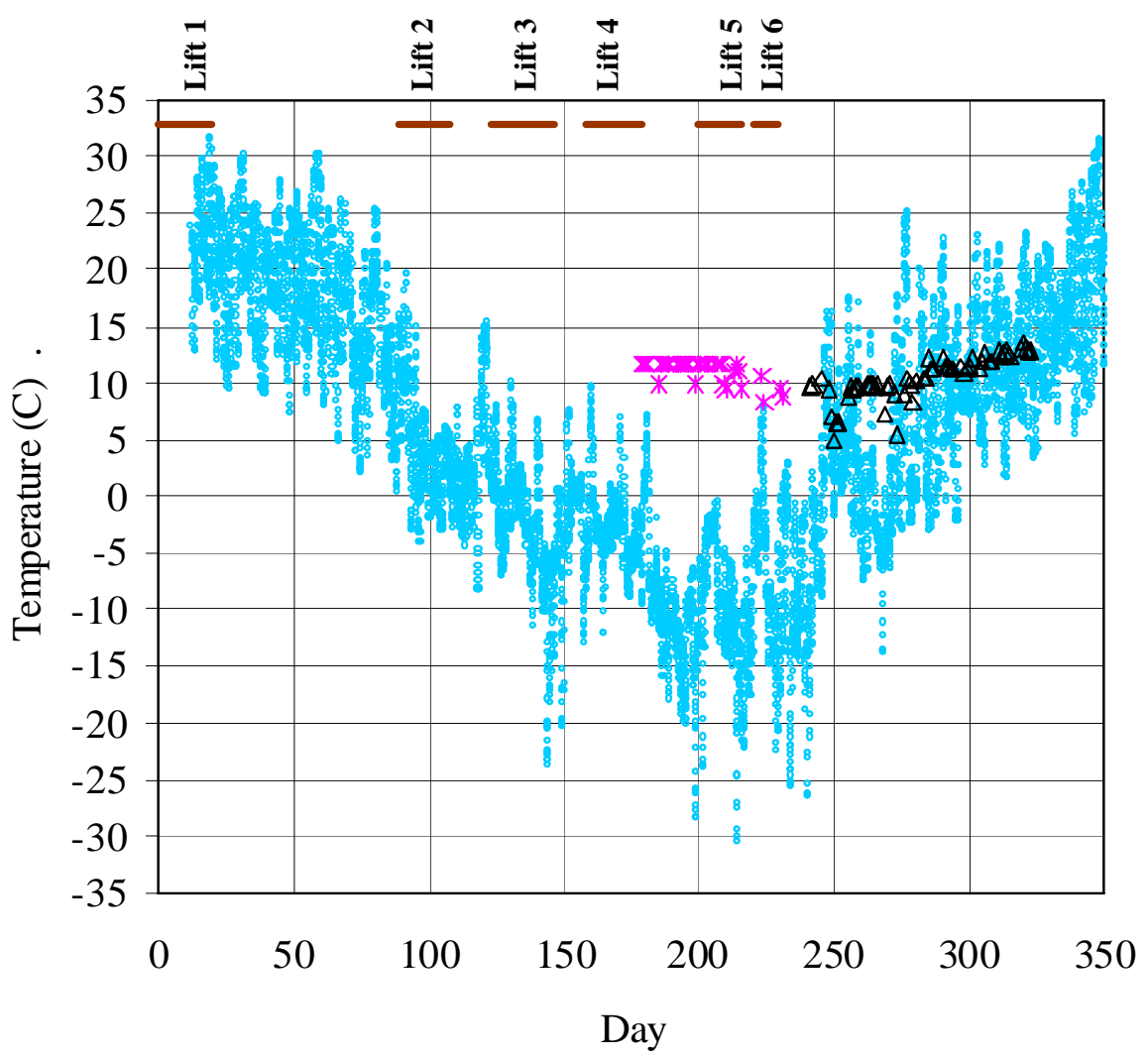

- Air $\Delta$ In Sump * Injected Leachate — Filing Date

Figure 7-22: The air temperature, leachate temperature in bioreactor sump and injected leachate.

The temperature of leachate at this site was between 10 and $12{ }^{\circ} \mathrm{C}$ (Figure 7-22). Its injection raised the temperature in colder lifts (Lifts 3, 4, and 5; figure 7-23) and decreased the temperature in the warmer lifts (Lifts 1 and 2; Figure 7-23). Due to operational difficulties, leachate injection was stopped in late 
winter, and only a small amount of leachate was injected into top three lifts (Lifts 4, 5, and 6; Figure 723). The temperature in the Lifts 4 and 5 remained low (Figure 7-23).

The waste decomposition rate slowed dramatically due to the low temperature conditions. As shown in Figure 7-16, measurable levels of methane were found in Lift 1, approximately 68 days after filling, and that methane concentration increased continuously. However, very low levels of methane were found in Lift 3, even after 260 days of filling. This low level of methane could even be due to gas transport from the lower lifts. Even though the temperature in both lifts was similar 260 days after the filling completed, Lift 1 started with a higher temperature $\left(30^{\circ} \mathrm{C}\right)$ and Lift 3 was started at $5{ }^{\circ} \mathrm{C}$. It is well known that methanogenic activity reduces substantially at lower temperatures. This observation of delayed start-up of anaerobic activity in lifts filled at colder temperatures has repercussions in the overall operation of anaerobic bioreactor landfills in colder climates. 

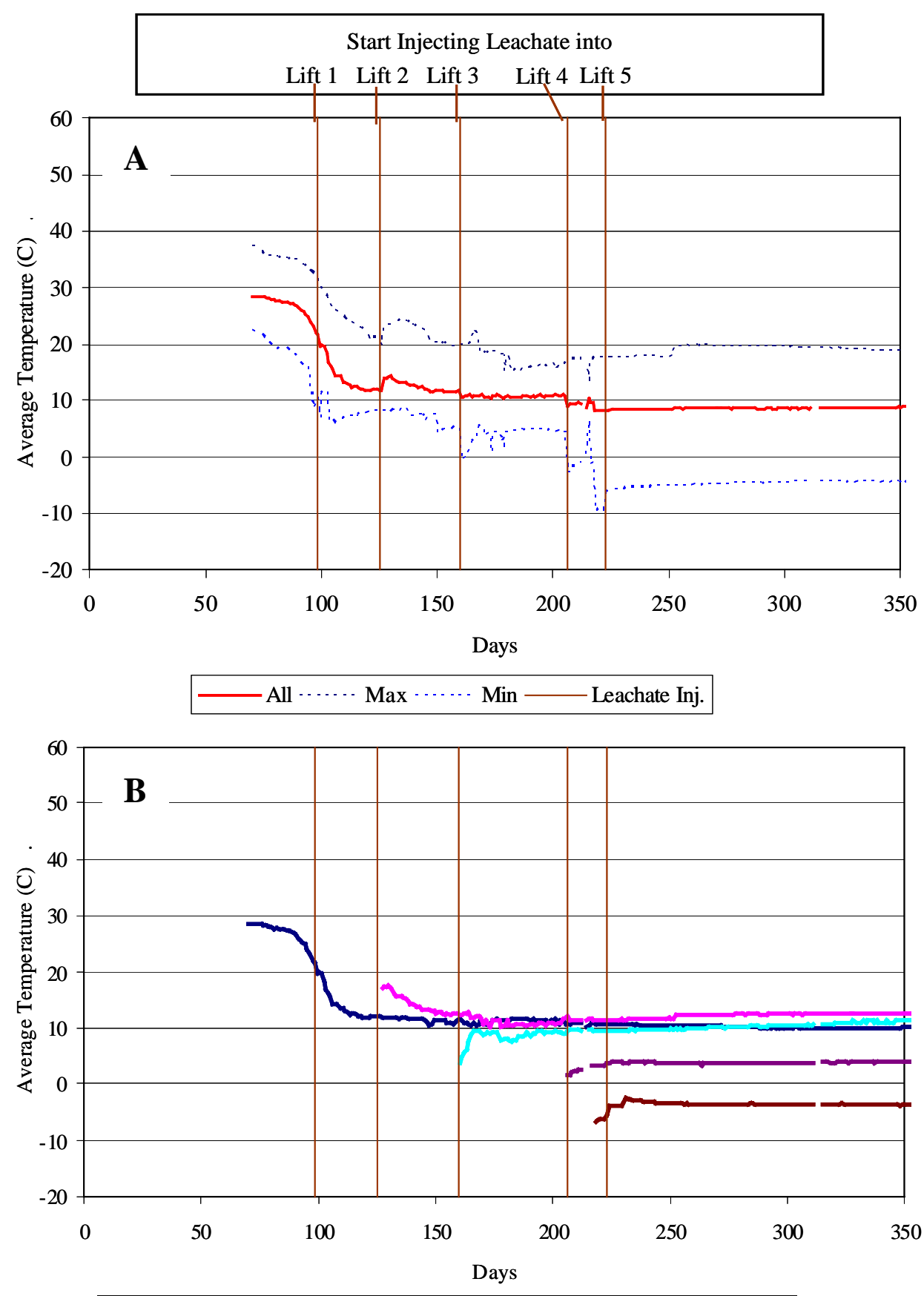

Lift $1-$ Lift $2=$ Lift $3-$ Lift $4-$ Lift $5-$ Leachate Inj.

Figure 7-23: The average, maximum and minimum temperatures in the bioreactor (A) and the average temperature in each lift (B) 


\section{CHAPTER 8: CONCLUDING REMARKS}

A 1.2 acre bioreactor landfill cell was constructed and operated in the State of Michigan. A total of 35,317 tons of MSW and 20,777 tons of cover soil were compacted in the cell. The total in placed volume was 74,239 cubic yards. The horizontal leachate injection/recirculation pipes and gas collection pipe were installed at every $10 \mathrm{ft}$ lift. Leachate generated on-site from existing cells was used as moisture source to increase the moisture content in the waste. Total of 4.1 million gallons of water entered in the cell, while 2.2 million gallons of water was retained in the waste. The target 35\% moisture content (wet based) was easily achieved. Using a dedicated sump, leachate quantity and quality was continuously monitored.

Performance of the bioreactor landfill was monitored using a set of probes and sampling ports installed in a three-dimensional monitoring grid consisting of 48 locations. Moisture and temperature was continuously monitored in situ at these locations. Gas and leachate samples were collected through sampling ports from all the 48 locations in the cell. Deferential settlement was evaluated using settlement profiler conduits. With the capability to measure leachate and gas characteristics, temperature, and settlement in three dimensions, the cell is expected to provide a better understanding of the processes occurring within a bioreactor cell located in cold climates.

Preliminary results related to moisture content measurement indicated that it was distributed relatively evenly throughout the waste. This statement is made only in the context of landfills, where heterogeneity is the rule rather than exception. By laying the leachate recirculation pipes on top of the compacted waste, the lateral movement of the injected leachate was enhanced. At a rate of 25 to 30 gal per cubic yard of compact waste, the moisture in the landfill cell was considered to be non-limiting for biological activity.

The gas composition in the cell indicated an early production of methane at the lower lift, which was filled in the summer months. However, the gas production in the lift filled in winter months remained low for a much longer duration. The temperature data showed the existence of very low temperature zones (layers) within the landfill. The thermal insulation capacity of the waste was considered to be the main reason for the prolonged low temperature conditions in the landfill, even several months after the cell was closed. This observation has repercussions for start-up and operation of bioreactor landfills in colder climates. It can be concluded that besides moisture content, temperature may play an important role in initiating the biological decomposition process for bioreactor landfills, especially if the waste is placed during colder months. 


\section{REFERENCES}

Augenstein, D., Yazdani, R., Moore, R., and Dahl, K. (1997). "Yolo county controlled landfill demonstration project." 43-83.

Barlaz, M. A., Ham, R. K., and Schaefer, D. M. (1990). "Methane Production from Municipal Refuse: A Review of Enhancement Techniques and Microbial Dynamics." CRC Critical Reviews in Environmental Control, 19(6), 557 - 584.

Barry, R. M., and Demme, D. C. (1997). "Design innovations at the DSWA's latest landfill expansion project." WASTECON Proceedings.

Dahl, K. (1998). "Reuse of shredded waste tires for landfill gas collection and leachate injection systems in Yolo county's landfill bioreactor demonstration project." Proceedings from SWANA's 21st Annual Landfill gas symposium. March 1998, Yolo County, California, 103-117.

Li, R. S., and Zeiss, C. (2001). "In situ Moisture Content Measurement in MSW Landfills with TDR." Environmental Engineering Science, 18(1), 53-66.

Maier, T. B. e. a., Steinhauser, E. S., Vasuki, N. C., and Pohland, F. G. (1995). "Integrated Leachate and Landfill Gas Management." Sardinia 95: Fifth international Landfill Symposium, Sardinia, Italy, 16.

McCreanor, P. T., and Reinhart, D. R. (1999). "Hydrodynamic modeling of leachate recirculating landfills." Waste Management \& Research, 17, 465-469.

Mehta, R., Barlaz, M. A., Yazdani, R., Augenstein, D., Bryars, M., and Sinderson, L. (2002). "Refuse Decomposition in the Presence and Absence of Leachate Recirculation." Journal of Environmental Engineering, 128(3), 228-236.

Moore, R., Karina, D., and Yazdani, R. (1997). "Hydraulic characteristics of Municipal Solid Waste: Finding of the Yolo county Bioreactor landfill Project." The thirteen International Conference on Solid Waste Technology and Management, Philadelphia, PA.

NETL. (2005). "Carbon Sequestration: Technology Roadmap and Program Plan 2005." U.S. Department of Energy, Office of Fossil Energy, National Energy Technology Laboratory.

Pacey, J., Reinhart, D. R., Hansen, D. L., Townsend, G. T., and Johnson, W. H. (1999). "Landfill Bioreactor-An Innovation in Solid Waste Management." SWANA 22nd Annual LFG Symposium.

Pagano, J. J., Scrudato, R. J., and Summer, G. M. (1998). "Leachate recirculation at the Nanticoke Sanitary Landfill using a bioreactor trench." NYSERDA report 98-6.

Pohland, F. G. (1980). "Leachate recycle as landfill management option." Journal of the Environmental Engineering Division, ASCE, 106(EE6), 1057-1069.

Reinhart, D., McCreanor, P. T., and Townsend, G. T. (2002). "The bioreactor landfill: Its status and future." Waste Management \& Research, 20, 172-186.

SWANA. (2002). The Solid Waste Manager's Guide to the Bioreactor Landfill, Solid Waste Association of North America. 
Townsend, T. G., Miller, W. L., BISHOP, R. A., and Carter, J. H. (1994). "Combining systems for Leachate recirculation and landfill gas collection." Solid Waste Technologies, 18-24.

Townsend, T. G., Miller, W. L., Lee, H. J., and Earle, J. F. K. (1996). "Acceleration of landfill stabilization using leachate recycle." Journal of Environmental Engineering-ASCE, 122(4), 263-268.

Warzinski, J., Watermolen, B. T., and Genthe, D. R. (2000). "A superior approach to recirculation." Waste Age.

Wilson, V. L., Evans, W. D., Stark, T. D., and Repa, E. (2000). "An Interim Slope Failure Involving Leachate Recirculation." Municipal and Industrial Solid Waste Disposal Technology Waste Tech 2000, Orlando, Florida.

Yuen, S. T. S., Wang, Q. J., Styles, R. R., and A., M. T. (2001). "Water balance comparison between a dry and a wet landfill - a full-scale experiment." Journal of Hydrology, 251, 29-48.

Zhao, X., Maher, S., Musleh, R., Khire, M., Voice, T., and Hashsham, S. (2003). "Full-scale evaluation of bioreactor landfill technology." SWANA 8th Annual Landfill Symposium, Atlantic City, NJ.

Zhao, X., Voice, T. C., Khire, M., Musleh, R., Maher, S., and Hashsham, S. (2004). "Bioreactor Landfill at Northern Oaks Landfill, Michigan." SWANA 9th Annual Landfill Symposium, Monterey, CA. 